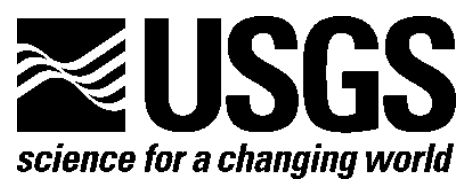

\title{
Population Dynamics of the Northern Tamarisk Beetle (Diorhabda carinulata) in the Colorado River Basin
}

By Levi R. Jamison and Charles van Riper III

Open-File Report 2018-1070

U.S. Department of the Interior

U.S. Geological Survey 


\section{U.S. Department of the Interior \\ RYAN K. ZINKE, Secretary}

\section{U.S. Geological Survey \\ William H. Werkheiser, Deputy Director \\ exercising the authority of the Director}

U.S. Geological Survey, Reston, Virginia: 2018

For more information on the USGS—-the Federal source for science about the Earth, its natural and living resources, natural hazards, and the environment-visit https://www.usgs.gov/ or call 1-888-ASK-USGS (1-888-275-8747).

For an overview of USGS information products, including maps, imagery, and publications, visit https://store.usgs.gov/.

Any use of trade, firm, or product names is for descriptive purposes only and does not imply endorsement by the U.S. Government.

Although this information product, for the most part, is in the public domain, it also may contain copyrighted materials as noted in the text. Permission to reproduce copyrighted items must be secured from the copyright owner.

Suggested citation:

Jamison, L.R., and van Riper, C., III, 2018, Population dynamics of the northern tamarisk beetle (Diorhabda carinulata) in the Colorado River Basin: U.S. Geological Survey Open-File Report 20181070, 67 p., https://doi.org/10.3133/ofr20181070.

ISSN 2331-1258 (online) 


\section{Contents}

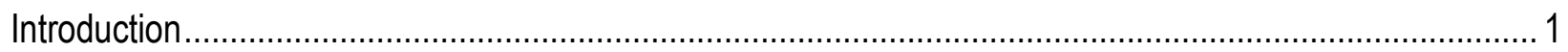

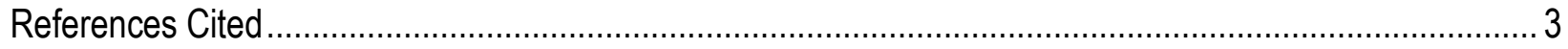

Chapter 1. The Influence of Tamarix ramosissima Defoliation on Population Movements of the Northern Tamarisk Beetle (Diorhabda carinulata) on the Colorado Plateau ..................................................... 6

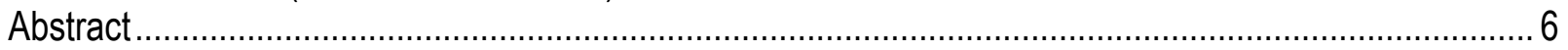

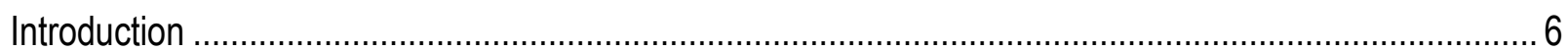

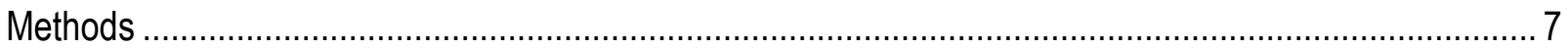

Study Sites

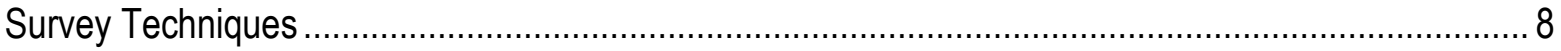

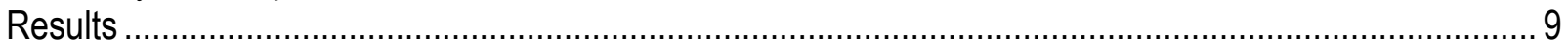

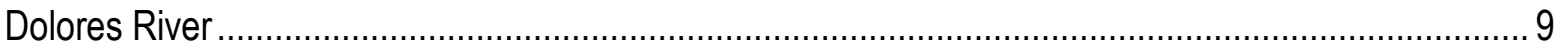

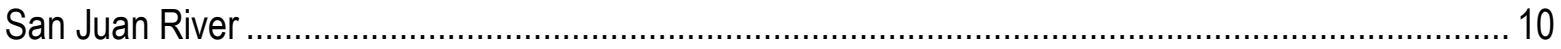

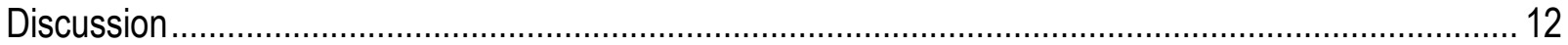

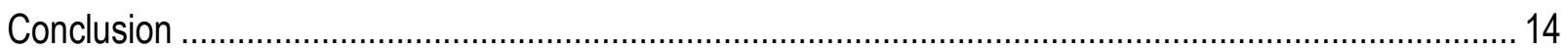

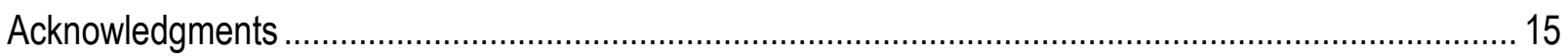

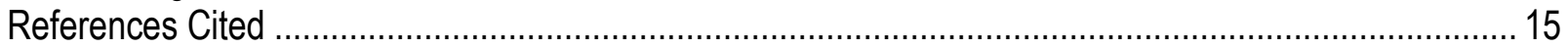

Chapter 2. Utilizing Temperature, Day Length, and Diorhabda carinulata Geographic Distribution for

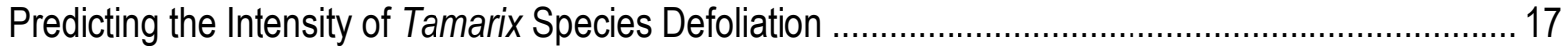

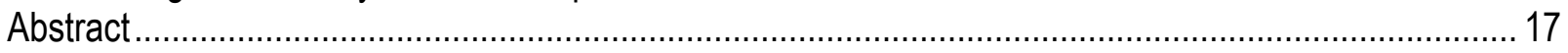

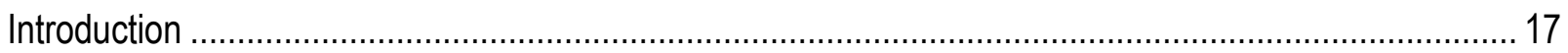

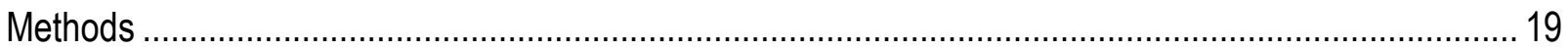

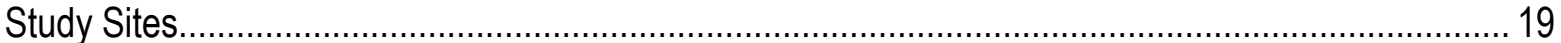

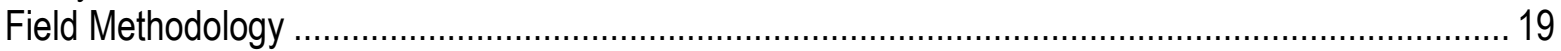

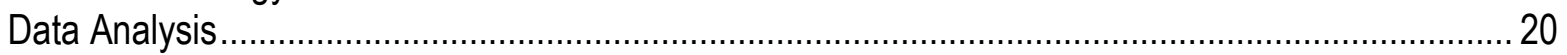

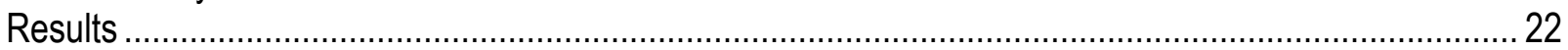

Influence of Abiotic Cues on Seasonal Timing........................................................................... 22

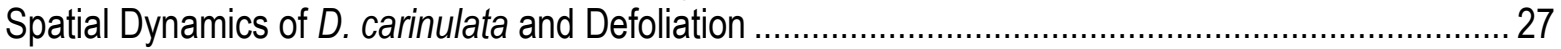

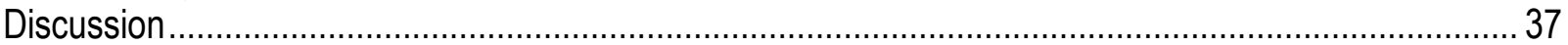

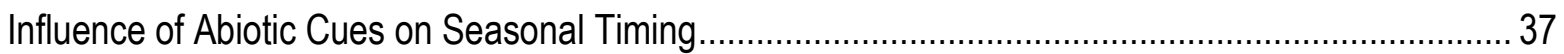

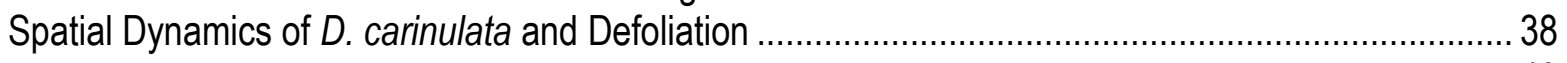

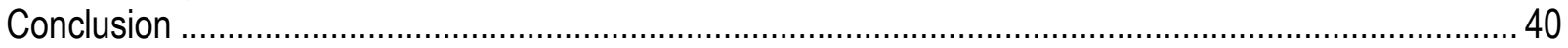

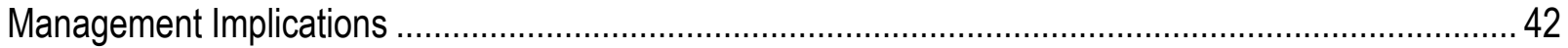

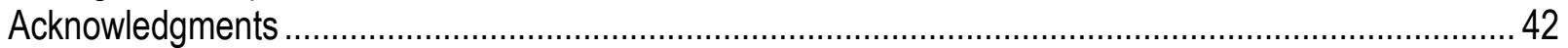

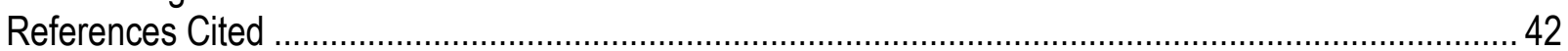

Appendix 1. Temperature and Day-Length Data for Study Sites in the Colorado River basin, 2011-12 ..... 46 


\section{Figures}

1. Map of the Colorado, San Juan, San Miguel, and Dolores Rivers in Utah and Colorado, showing locations of study sites on the Dolores and San Juan Rivers.

2. Distribution of Diorhabda carinulata adults and larvae and resulting tamarisk defoliation along the Dolores River between the confluences of the Colorado River and the San Miguel River in August 2008.

3. Comparative distributions of Diorhabda carinulata adults recorded along the Dolores River in 2008-10.

4. Comparative distributions of Diorhabda carinulata adults and larvae and tamarisk defoliation levels recorded in late July 2010 along the San Juan River between Bluff, Utah, and Clay Hills Crossing, Utah 13

5. Map of the Colorado and San Juan Rivers in Arizona and New Mexico showing study site locations.

6. Diorhabda carinulata population distributions in 2011 at the San Juan and Marble Canyon study sites.

7. Average daily temperatures at study sites in the Colorado River basin, with timing of initial reproductive activity in 2011 and 2012

8. Mean defoliation levels at the Marble Canyon, Grand Canyon, and San Juan study sites in the Colorado River basin in 2011.

9. Monthly distributions of Diorhabda carinulata along the San Juan River near Farmington, New Mexico, along the Colorado River in Marble Canyon and in the Grand Canyon, Arizona.

10. Number of first-summer-generation larvae versus defoliation level one month later at study sites in the Colorado River basin in 2011.

11. Number of Diorhabda carinulata versus defoliation level at study sites in the Colorado River basin midsummer 2011

12. Spatial distributions of Diorhabda carinulata larvae and respective defoliation levels along the San Juan River near Farmington, New Mexico, along the Colorado River in Marble Canyon and the Grand Canyon, Arizona.

13. Mean sample abundance of Diorhabda carinulata per monthly survey at the Marble Canyon, Grand Canyon, and San Juan study sites in the Colorado River basin in 2011

\section{Tables}

1. Diorhabda carinulata population per sampling period at the San Juan, Marble Canyon, and Grand

Canyon study sites

2. Linear movement of Diorhabda carinulata population boundaries from May to August (Marble Canyon, Grand Canyon study sites) and from June to September 2011 (San Juan study site) ..... 33

3. Collections of live and dead Diorhabda carinulata in leaf litter at the San Juan, Marble Canyon, and Grand Canyon study sites in the Colorado River basin in winter 2011-12. 


\title{
Population Dynamics of the Northern Tamarisk Beetle (Diorhabda carinulata) in the Colorado River Basin
}

\author{
By Levi R. Jamison ${ }^{1}$ and Charles van Riper III2
}

\section{Introduction}

Throughout the Southwestern United States, riparian systems contain narrow belts of vegetation along streams and rivers. Although riparian vegetation contributes to only a small percentage of the total land cover ( $<10$ percent), it is important for maintaining high species diversity and population densities of birds (Anderson and Ohmart, 1977; Krueper and others, 2003; Brand and others, 2010). Anthropogenic changes to Western riverine systems have enhanced their susceptibility to invasion by introduced plant species (Baker, 1986, Mack and others, 2000), in particular, beginning in the late 1800s, the invasion of ornamental plants from the genus Tamarix, called "saltcedar" (Tamarix spp.) or "tamarisk" (Robinson, 1965; Knopf and others, 1988; Earnst and others, 2005; Stromberg and others, 2007).

Tamarisk had been credited with many negative ecologic and economic effects (Cleverly and others, 1997; Shafroth and others, 2005) because the plant can establish itself in dry, salty conditions and spread at rates of $>20$ kilometers per year $(\mathrm{km} / \mathrm{yr})$. In many areas, tamarisk is now a dominant plant on the banks of rivers, streams, springs, and ponds throughout the Southwest (Busch and Smith, 1995; Glenn and Nagler, 2005; Hultine and others, 2010). Tamarisk is considered to have negative impacts on riparian ecosystem structure and processes, including disruption of water use (Shafroth and others, 2005), displacement of native vegetation (Stromberg and others, 2007; Glenn and Nagler, 2005), increased fire frequencies (Busch and Smith, 1993), decreased biodiversity (Harms and Hiebert, 2006), and reduced habitat quality for wildlife (Rice and others, 1980; Bailey and others, 2001; van Riper and others, 2008). Current financial losses due to tamarisk invasion along riparian areas in the United States, adjusted for inflation, are estimated at \$169-362 million (Zevaleta, 2000) and certainly millions of dollars more are spent annually for eradication and restoration projects.

Owing to these great financial losses, the biological control of invasive plant species is commonly a priority for land management in the restoration of Southwestern riparian ecosystems. Although tamarisk control has become targeted as an important aspect of local, State, and Federal programs, attempts to eradicate this introduced plant have been met with varying success. Traditional control strategies, such as mechanical removal, fire, and herbicide treatments, can be costly, unsuccessful, or have negative impacts on the establishment of native plant and soil communities.

In 1996, the U.S. Department of Agriculture Animal and Plant Health Inspection Service approved the release of the central Asian saltcedar leaf beetle (or tamarisk beetle), Diorhabda elongata Brulle (De Loach and others, 2000; Dudley, 2005), as a biocontrol for tamarisk. On the

\footnotetext{
${ }^{1}$ University of Arizona.

${ }^{2}$ U.S. Geological Survey.
} 
Colorado Plateau, the biological control of tamarisk by the tamarisk beetle, first implemented in 2001, has resulted in expanding beetle populations in Nevada, Utah, Colorado, and Wyoming (Bloodworth and others, 2016), leading to widespread tamarisk defoliation (Dennison and others, 2009; Meng and others, 2012) and concerns from land managers regarding the consequences of the environmental impact. Repeated herbivory and defoliation can result in as much as 40 percent tamarisk mortality within 5 years (Dudley and others, 2001; Hultine and others, 2010) in many areas. Defoliation can also negatively impact avian communities in the short term by decreasing insect abundance and nesting success, owing to increased solar radiation or loss of camouflage (Paxton and others, 2011; Peterson and others, 2015). Biologic control agents may also have other unexpected effects, especially on native bird species (Simberloff and Stiling, 1996). Therefore, careful monitoring of ecosystem restoration activities and of the interactions between biologic control agents and native wildlife communities is essential, so that the appropriateness of any control method and its overall success can be objectively evaluated (Blossey, 1999).

This report consists of two chapters detailing two recent studies that examine the spread of the introduced tamarisk beetle (Diorhabda carinulata) over parts of the Southwestern United States. The first chapter, entitled "The Influence of Tamarix ramosissima Defoliation on Population Movements of the Northern Tamarisk Beetle (Diorhabda carinulata) on the Colorado Plateau," documents plant phenology and beetle abundance and movement along the Dolores and San Juan Rivers, two major tributaries of the Colorado River. This study demonstrates that D. carinulata population-movement patterns can be highly influenced by the availability of beetle food resources and that local beetle "boom and bust" events are common. Beetles have defoliated 35 to 65 kilometers $(\mathrm{km})$ of river-corridor tamarisk habitat each year, with a pattern of temporary abandonment followed by recolonization of that habitat in the subsequent year. Larvae occurred primarily in areas of partial defoliation, whereas adults occurred throughout the river corridor, but mostly on the leading edge of defoliated reaches. Understanding this type of beetle behavior and population movement will be useful in the management of areas where $D$. carinulata has been established, as well as areas that it has not yet colonized. This information will also assist land managers to better understand how defoliation and the presence of $D$. carinulata influence tamarisk-dominated habitats within Colorado Plateau riparian ecosystems.

The second chapter, entitled "Utilizing Temperature, Day Length, and Diorhabda carinulata Geographic Distribution for Predictions of Tamarix spp. Defoliation," carries forward a similar theme of predicting tamarisk beetle abundance and movement. This study demonstrates that the extent and timing of tamarisk defoliation are predictable on the basis of (1) abiotic cues for $D$. carinulata activity, (2) spatial distributions and abundances of $D$. carinulata across a site, and (3) movement of $D$. carinulata as a result of available tamarisk foliage. The study also demonstrates that when spring temperatures averaged $>15^{\circ} \mathrm{C}$, D. carinulata soon began reproducing, increasing the rate of defoliation at a site. The defoliation pattern also led to variations in D. carinulata voltinism rates.

Critical day length is important for inducing diapause in D. carinulata, and this diapause is now 33-47 minutes shorter than that of the populations first released in North America in 2001, suggesting adaptation by the tamarisk beetle in response to abiotic cues. A significant positive correlation exists between the spatial distributions of $D$. carinulata populations in the fall and those of the first generation of larvae in the following spring, suggesting that the extent of tamarisk defoliation as a result of abundant larval populations is predictable. The abundance of D. carinulata decreased significantly at sites of 50 percent defoliation relative to sites of 100 
percent defoliation, indicating that $D$. carinulata will abandon certain areas once defoliation levels become high. At one site, beetle populations spread $19.3 \pm 5.6 \mathrm{~km}$ along a river corridor, and the overall range of this population over several years increased by $62.8 \pm 5.6 \mathrm{~km}$ along a linear riparian corridor.

The results of these two studies will enable conservationists to better understand the variable timing of tamarisk defoliation events across a landscape and provide a template to forecast tamarisk defoliation levels and rates in areas that have yet to be colonized by $D$. carinulata.

\section{References Cited}

Anderson, B.W. and Omhart, R.D., 1977, Vegetation structure and bird use in the lower Colorado River Valley, in Johnson, R.R. and Jones, D.A., eds., Importance, preservation, and management of riparian habitat-A symposium: Fort Collins, Colo., U.S. Forest Service, Rocky Mountain Forest and Range Experiment Station General Technical Report RM-43, p. 23-34.

Bailey, J.K., Schweitzer, J.A., and Whitham, T.G., 2001, Salt cedar negatively affects biodiversity of aquatic macroinvertebrates: Wetlands, v. 21, no. 3, p. 442-447.

Baker, H.G., 1986, Patterns of plant invasion in North America, in Mooney, H.A. and Drake, J.A., eds., Ecology of biological invasions of North America and Hawaii: New York, SpringerVerlag, p. 44-58.

Bloodworth, B.R., Shafroth, P.B., Sher, A., Manners, R.B., Bean, D.W., Johnson, M.J., and Hinojosa-Huerta, O., 2016, Tamarisk beetle (Diorhabda spp.) in the Colorado River basinSynthesis of an expert panel forum: Grand Junction, Colorado Mesa University, Technical Report Series, no. 1, p. 1-19.

Blossey, B., 1999, Before, during, and after-The need for long-term monitoring of invasive plant species management: Biological Invasions, v. 1, p. 301-311.

Brand, L.A., Stromberg J.C., and Noon, B.R., 2010, Avian density and nest survival on the San Pedro River-Importance of vegetation type and hydrologic regime: Journal of Wildlife Management, v. 74, p. 739-754.

Busch, D.E., and Smith, S.D., 1993, Effects of fire on water and salinity relationships of riparian woody taxa: Oecologia, v. 94, p. 186-194.

Busch, D.E. and Smith, S.D., 1995, Mechanisms associated with decline of woody species in riparian ecosystems of the southwestern U.S.: Ecological Monographs, v. 65, p. 347-370.

Cleverly, J.R., Smith, S.D., Sala, A., and Devitt, D.A., 1997, Invasive capacity of Tamarix ramosissima in a Mojave Desert floodplain-The role of drought: Oecologia, v. 111, p. 12-18.

DeLoach, C.J., Carruthers, R.I., Lovich, J.E., Dudley, T.L., and Smith, S.D., 2000, Ecological interactions in the biological control of saltcedar (Tamarix spp.) in the United States-Toward a new understanding: International Symposium on Biological Control of Weeds, 10th, Bozeman, Mont., 2000, Proceedings, p. 819-873.

Dennison, P.E., Nagler, P.L., Hultine, K.R., Glenn, E.P., and Ehleringer, J.R., 2009, Remote monitoring of tamarisk defoliation and evapotranspiration following saltcedar leaf beetle attack: Remote Sensing of Environment, v. 113, p. 1462-1472.

Dudley, T.L., 2005, Progress and pitfalls in the biological control of saltcedar (Tamarix spp.) in North America: U.S. Department of Agriculture Interagency Research Forum on Gypsy Moth and Other Invasive Species, 16th, Annapolis, Md., 2005, Proceedings (Morgantown, W. Va., U.S. Forest Service General Technical Report NE-337), p. 12-15. 
Dudley, T.L., DeLoach, C.J., Lewis, P.A., and Carruthers, R.I., 2001, Cage tests and field studies indicate leaf-eating beetle may control saltcedar: Ecological Restoration, v. 19, p. 260-261.

Earnst, S.L., Ballard, J.A., and Dobkin, D.S., 2005, Riparian songbird abundance a decade after cattle removal on Hart Mountain and Sheldon National Wildlife Refuges, in Bird conservation implementation and integration in the Americas: International Partners in Flight Conference, 3d, Albany, Calif., 2005, Proceedings (U.S. Forest Service, Pacific Southwest Research Station Report PSW-GTR-191), p. 550-558.

Glenn, E.P., and Nagler, P.L., 2005, Comparative ecophysiology of Tamarix ramosissima and native trees in western U.S. riparian zones: Journal of Arid Environments, v. 61, p. 419-446.

Harms, R., and Hiebert, R., 2006, Vegetation response following invasive tamarisk (Tamrix spp.) removal and implications for riparian restoration: Restoration Ecology, v. 14, p. 462-472.

Hultine, K.R., Nagler, P.L., Snyder, K.A., Uselman, S.M., and West, J.B., 2010, Tamarisk biocontrol in the western United States-Ecological and societal implications: Frontiers in Ecology and the Environment, v. 8, p. 467-474.

Knopf, F.L., Johnson, R.R., Rich, T., Samson, F.B., and Szaro, R.C., 1988, Conservation of riparian ecosystems in the United States: Wilson Bulletin, v. 100, p. 272-284.

Krueper, D., Bart, J., and Rich, T.D., 2003, Response of vegetation and breeding birds to the removal of cattle on the San Pedro River, Arizona, U.S.A.: Conservation Biology, v. 17, p. 607-615.

Mack, R.N., Simberloff, D., Lonsdale, W.M., Evans, H., Clout, M., and Bazzaz, F.A., 2000, Biotic invasions - Causes, epidemiology, global consequences, and control: Ecological Applications, v. 10, p. 689-710.

Meng, R., Dennison, P.E., Jamison, L.R., van Riper III, C., Nagler, P.L., Hultine, K.R., Bean, D.W., Dudley, T., 2012, Detection of tamarisk defoliation by the northern tamarisk beetle based on multitemporal Landsat 5 thematic mapper imagery: GIScience \& Remote Sensing, v. 49, p. 510-537.

Paxton, E.H., Theimer, T.C., Sogge, M.K., 2011, Tamarisk biocontrol using tamarisk beetlesPotential consequences for riparian birds in the southwestern United States: Condor, v. 113, p. 255-265.

Peterson, D., Pellegrini, A.R., McLeod, M.A., and Theimer, T.C., 2015, Distance to standing water is negatively correlated with invertebrate biomass, nestling feeding rate and productivity in Southwestern Willow Flycatchers (Empidonax trailli extimus), in Huenneke, L.F., van Riper III, C., Hays-Gilpin, K.A., eds., The Colorado Plateau VI-Science and management at the landscape scale: Tucson, Ariz., University of Arizona Press, p. 262-270.

Rice, J., Anderson, B., and Ohmart, R., 1980, Seasonal habitat selection by birds in the Lower Colorado River Valley: Ecology, v. 61, p. 1,402-1,411.

Robinson, T.W., 1965, Introduction, spread and areal extent of saltcedar (Tamarix) in the Western States: U.S. Geological Survey Professional Paper 491-A, 12 p.

Shafroth, P.B., Cleverly, J.R., Dudley, T.L., Taylor, J.P., van Riper, C., III, Weeks, E.P., and Stuart, J.N., 2005, Control of Tamarix in the western United States-Implications for water salvage, wildlife use, and riparian restoration: Environmental Management, v. 35, p. 231-246.

Simberloff, D., and Stiling, P., 1996, Risks of species introduced for biological control:

Biological Conservation, v. 78, p. 185-192.

Stromberg, J.C., Lite, S.L., Marler, R., Paradzick. C., Shafroth, P.D., Shorrock, D., White, J.M., and White, M.S., 2007, Altered stream-flow regimes and invasive plant species-The Tamarix case: Global Ecology and Biogeography, v. 16, p. 381-393. 
van Riper, C., III, Paxton, K.L., O’Brien, C., Shafroth, P.B., and McGrath, L.J., 2008, Rethinking avian response to Tamarix on the Lower Colorado River-A threshold hypothesis: Restoration Ecology, v. 16, p. 155-167.

Zavaleta, E., 2000, The economic value of controlling an invasive shrub: Ambio, v. 29, p. 462467. 


\title{
Chapter 1. The Influence of Tamarix ramosissima Defoliation on Population Movements of the Northern Tamarisk Beetle (Diorhabda carinulata) on the Colorado Plateau
}

\begin{abstract}
The northern tamarisk beetle (Diorhabda carinulata) was introduced into the Colorado River basin on the Colorado Plateau in 2004 in an effort to control invasive/exotic tamarisk (Tamarix ramosissima) plants. Since the initial release, rapid beetle colonization and subsequent defoliation of tamarisk have occurred along the Colorado River corridor. We collected plant phenology and beetle abundance data from the Dolores and San Juan Rivers, two major tributaries of the Colorado River, to document tamarisk defoliation and beetle movement patterns. We observed that $D$. carinulata population movement patterns are strongly influenced by the availability of food resources and local beetle "boom and bust" events appear to be common. Beetles defoliated from 35 to 65 kilometers $(\mathrm{km})$ of river-corridor tamarisk habitat each year. After intensive tamarisk defoliation of large riparian reaches, beetles displayed a pattern of temporary abandonment with recolonization of that same habitat in the subsequent year. Larvae appeared primarily in areas of partial defoliation, whereas adults appeared throughout the river corridor but most commonly on the leading edge of defoliated reaches. Understanding this type of beetle behavior and movement patterns will be useful in the management of both areas where $D$. carinulata has already been established and areas that it has not yet colonized. It will also assist land managers to better understand how defoliation and the presence of $D$. carinulata affect tamarisk-dominated habitats within Colorado Plateau riparian ecosystems.
\end{abstract}

\section{Introduction}

The northern tamarisk beetle (Diorhabda carinulata) was first formally introduced into the Western United States in 2001 (DeLoach and others, 2003) as a biological control agent for the invasive/exotic plant tamarisk (Tamarix ramosissima, or saltcedar). Since its introduction into the Colorado River basin in 2004, D. carinulata has rapidly expanded across the Colorado Plateau (Meng and others, 2012). Interest in D. carinulata has increased since these initial releases, owing to the beetle's rapid expansion and its ability to quickly defoliate large reaches of tamarisk habitat (Hultine and others, 2010a; Dudley and Bean, 2012; Snyder and others, 2012). With tamarisk now becoming a dominant part of many riparian ecosystems (Friedman and others, 2005), scientists and managers have questioned what influence D. carinulata would have on the plant component of these important ecosystems (van Riper and others, 2008; Hultine and others, 2010b; Dudley and Bean, 2012).

A foliage feeder within the family Chrysomelidae, $D$. carinulata feeds on the leaves of tamarisk, commonly leading to complete plant defoliation (Lewis and others, 2003; Hudgeons and others, 2007a, b; Snyder and others, 2012). Larvae appear to be responsible for most of the defoliation. During the adult beetle stage, aggregation events occur based on attraction to the males' aggregation pheromone (Cossé and others, 2005), resulting in extensive beetle concentrations in focused areas, similar to that for other Chrysomelid beetles (Bartelt and others, 2008). This aggregative characteristic can lead to the later establishment of dense larval populations in those areas. When larval development is synchronous, intensive episodic 
defoliation events result (Hultine and others, 2010a; Nagler and others, 2014). After larvae pupate, they emerge as winged adults. Individuals fly in search of food and are attracted to conspecific aggregations (Cossé and others, 2005; Bean and others, 2007a). Although tamarisk can commonly resprout new leaves within a few weeks after initial defoliation (Hultine and others, 2010a; Snyder and others, 2012), whole-plant mortality likely occurs after multiple years of repeated defoliation events (DeLoach and others, 2003; Dudley and Bean, 2012).

As day length begins to shorten in the fall, adult $D$. carinulata begin diapause and crawl into the leaf litter to overwinter (Bean and others, 2007a, b; Bean and others, 2012). Eventually, tamarisk also go dormant, and leaves senesce before the winter season (especially in northern colder climates), leaving both the host plant and D. carinulata dormant for a period of time. As days begin to lengthen and temperatures rise in the spring, tamarisk resprouts to form new canopies (minus any accrued branch mortality from past defoliation). As tamarisk develops green canopies, D. carinulata emerges as adults and searches for trees upon which to feed and reproduce (Lewis and others, 2003). Knowledge of the timing of $D$. carinulata activity and defoliation is useful when considering the extrinsic effects of defoliation (for example, cover for wildlife, avian nesting and foraging, and tamarisk evapotranspiration rates).

This chapter discusses the patterns of tamarisk defoliation and large-scale defoliation events that lead to temporary abandonment of an area by D. carinulata, when adult beetles emigrate in search of food resources. We demonstrate that tamarisk defoliation intensity and pattern greatly influence the future extent, timing, and abundance of $D$. carinulata and of subsequent beetle colonization and defoliation events.

\section{Methods}

\section{Study Sites}

We collected tamarisk phenologic and beetle-abundance data in 2008-10 along the Dolores and San Juan Rivers, two major tributaries of the Colorado River (fig. 1). This study complements our general 2006-13 landscape-distribution surveys of D. carinulata across the Colorado Plateau. The Dolores River in southwestern Colorado flows generally westward from the Rocky Mountains and then northwestward, where it joins the Colorado River north of Moab, Utah. Vegetation along the Dolores River consists of a fairly dense mix of tamarisk, willow (Salix exigua), scattered cottonwood (Populus fremontii), and boxelder (Acer negundo) riparian forests. The river within our study area flows through deep-walled ( 100-300 meter [m]) sedimentary rock canyons, with higher mountains and mesas above. The San Juan River in southern Utah flows through a more constricted and deep $(\sim 300 \mathrm{~m})$ sedimentary rock canyon, with sparser riparian vegetation cover consisting primarily of willow and tamarisk.

At the Dolores River, a large release of D. carinulata was made in 2004 at a site next to the confluence with the Colorado River, and a smaller release was made in August 2006 approximately $12 \mathrm{~km}$ upstream from the town of Gateway, Colorado. At San Juan River, a large release of D. carinulata was made in 2007 on the upstream bound of our study site in the town of Bluff, Utah (fig. 1), and another apparent release was made within the vicinity of Paiute Farms, Utah, at the upper extent of Lake Powell and the San Juan River's termination into the lake. Although this release was informal and undocumented, tamarisk defoliation was first detected at this location in 2008 (Meng and others, 2012). 


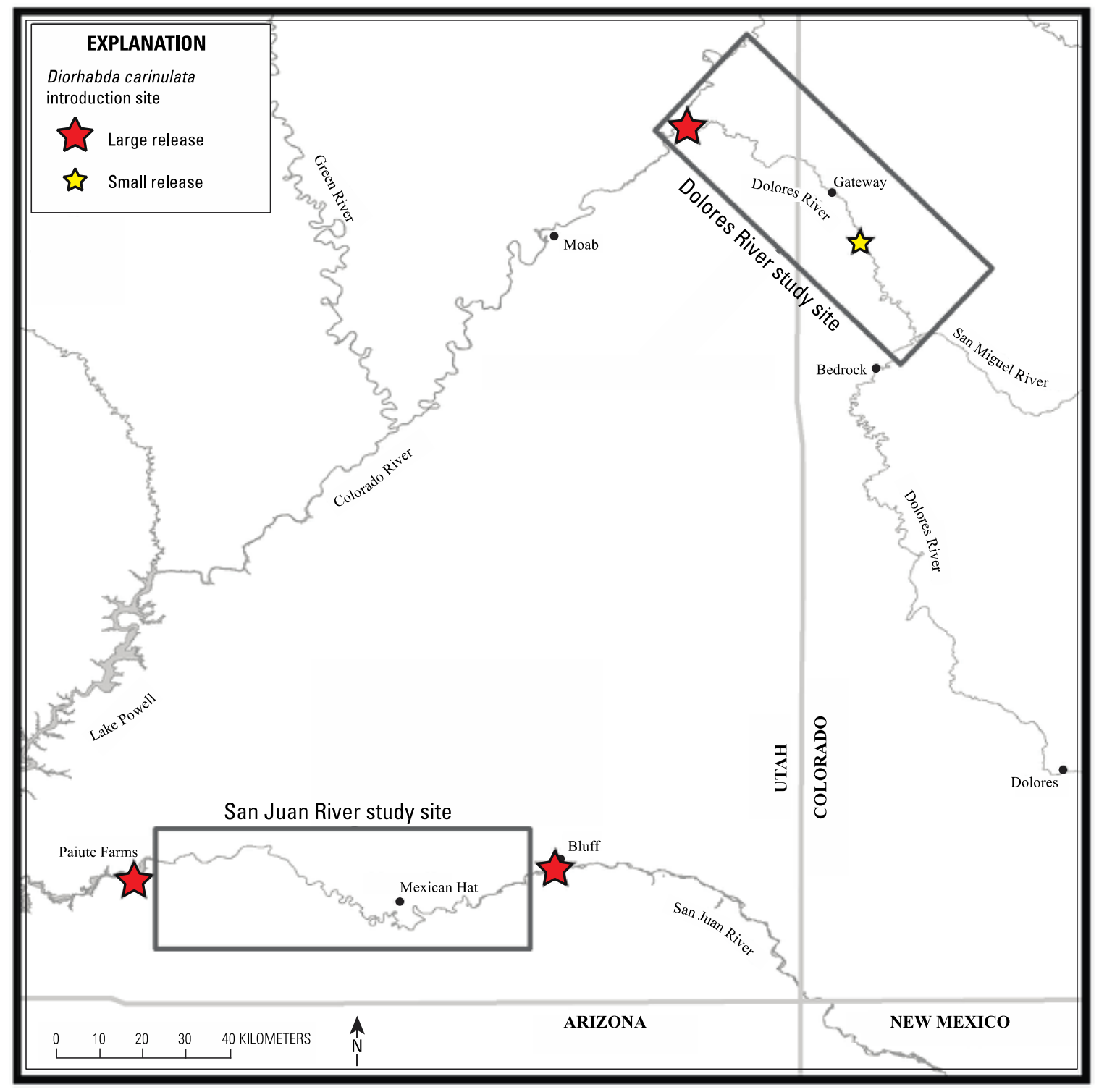

Figure 1. Map of the Colorado, San Juan, San Miguel, and Dolores Rivers in Utah and Colorado, showing locations of study sites on the Dolores and San Juan Rivers. Locations of Diorhabda carinulata release sites are marked with stars.

\section{Survey Techniques}

On the Dolores River, we surveyed at Bedrock, Colo., as well as from where the river is joined by the San Miguel River downstream to its confluence with the Colorado River (fig. 1). We sampled Bedrock in June 2008 and 2009 and along the river corridor during three periods: August 13-15, 2008; May 18-22, 2009; and May 31-June 3, 2010. We surveyed the San Juan River from Bluff, Utah, downstream to Clay Hills Crossing, $\sim 6 \mathrm{~km}$ upstream from Paiute Farms, during July 25-30, 2010. Along both rivers, we used a sweep net to recorded beetle numbers every $1.5 \mathrm{~km}$ and collected estimates of tree phenology and plant condition by direct observation. 
Data collected along the Dolores River involved 20 sweeps in tamarisk canopies at $1.5 \mathrm{~km}$ intervals. In each sweep, we recorded the total number of $D$. carinulata larvae and adults captured. We also visually estimated the average defoliation level of tamarisk within $\sim 100 \mathrm{~m}$ of each beetle sampling site. We distinguished defoliation levels as high (70-100 percent), medium (40-60 percent), low (10-30 percent), or absent (0 percent). Data collection along the San Juan River differed; here, we made 25 sweeps in the tamarisk canopies at $1.5-\mathrm{km}$ intervals and recorded defoliation levels in continuous increments of 10 percent. All surveys were conducted as part of a larger monitoring program to map the distribution of $D$. carinulata across the Colorado Plateau region.

\section{Results}

\section{Dolores River}

After its 2004 release at the junction of the Colorado and Dolores Rivers, D. carinulata spread slowly up the Dolores River drainage and reached the confluence with the San Miguel River (km 105) in late 2008. The beetle population at Gateway, Colo., did not achieve high densities and was assimilated by the more rapidly growing population of $D$. carinulata that expanded upstream from the Colorado River confluence in 2007-8.

Defoliation Levels - At Bedrock, Colo. (Dolores River km 156), in early June 2008, beetles were not detected, and tamarisk canopy cover was almost complete ( 87 percent) for 100 sampled trees. By late June, 64 percent of the tamarisk canopy at this site contained green leaves and 6 percent of the canopy was brown. In July, only 11 percent remained green and 62 percent of the canopy had turned brown from beetle defoliation, indicating that beetles had reached the vicinity of Dolores River km 150 by mid-2008. In August, we observed high (average 97 percent) defoliation levels along the entire Dolores River study area (fig. 2). Extending from the confluence with the Colorado River upstream to $\mathrm{km}$ 68.5, we measured defoliation levels consistently at 100 percent (fig. 2). From the edge of this high-defoliation-level zone upstream to the San Miguel River, defoliation levels averaged 57 percent with no defoliation recorded at only one sampling site. In June 2009, the Bedrock site had only 23 percent green leaves and 42 percent of the canopy had turned brown from beetle damage. Defoliation was not detected during our May 2010 river survey, but on May 18 at Bedrock, only 9.4 percent leaf cover remained on tamarisk.

Adult beetles - In August 2008, within the high-defoliation-level zone on the Dolores River ( $\mathrm{km} 0$ to $\sim 70$ ), we found only two adult beetles within the first $28.5 \mathrm{~km}$. We found small groups of adult beetles extending upriver another $38.5 \mathrm{~km}$ to the end of the completely defoliated

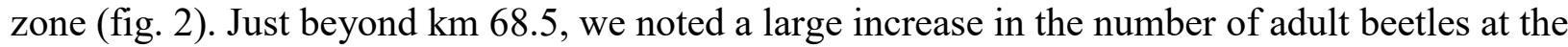
edge of the high-defoliation-level zone. From that point upstream to the confluence with the San Miguel River, we recorded only a few adult beetles. In May 2009, adult beetles again appeared along only the upper part of our Dolores River study area, but in larger numbers than we found in August 2008 (fig. 3). We detected small numbers of beetles from the Colorado River confluence upstream to $\mathrm{km} 36$, with few aggregations and small numbers of adult beetles extending upstream to $\mathrm{km} 62$. Numbers of adult beetles increased rapidly beginning at $\mathrm{km} 63$ upstream from the Colorado River, and larger numbers were found continuously from that point upstream to the San Miguel River. The largest numbers of adult beetles were recorded between 70 and $82 \mathrm{~km}$ upstream from the Colorado River (fig. 3). In May 2010, we noted a large shift in the distribution of adult beetles along the Dolores River. Most of the D. carinulata population 
had moved downstream to $59 \mathrm{~km}$ upstream from the Colorado River confluence, where they had been absent in our May 2009 survey (fig. 3). High numbers of adult beetles were found in the first $35 \mathrm{~km}$ upstream from the Colorado River, with peak numbers between $\mathrm{km} 37$ and 58 (fig. 3). Farther upstream to the San Miguel confluence (km 105), where adult beetles were abundant the previous May, beetle numbers were greatly reduced, and we recorded only a few aggregations.

Beetle larvae - During August 2008, we found only one larva within the $68.5 \mathrm{~km}$ length of the lower Dolores River high-defoliation-level zone (fig. $2 B$ ). Farther upstream in partially defoliated areas, we found larger numbers of larvae all the way to the San Miguel River confluence. Generally, more D. carinulata were present in the partially defoliated vegetation zone. We recorded only one larva during our May 2009 survey, as beetles had only recently emerged from overwintering and the first-generation larvae had not yet emerged. Our May 2010 survey was also early in the season, and we found only small numbers of larvae, all within the first $28 \mathrm{~km}$ upstream from the Colorado River confluence.
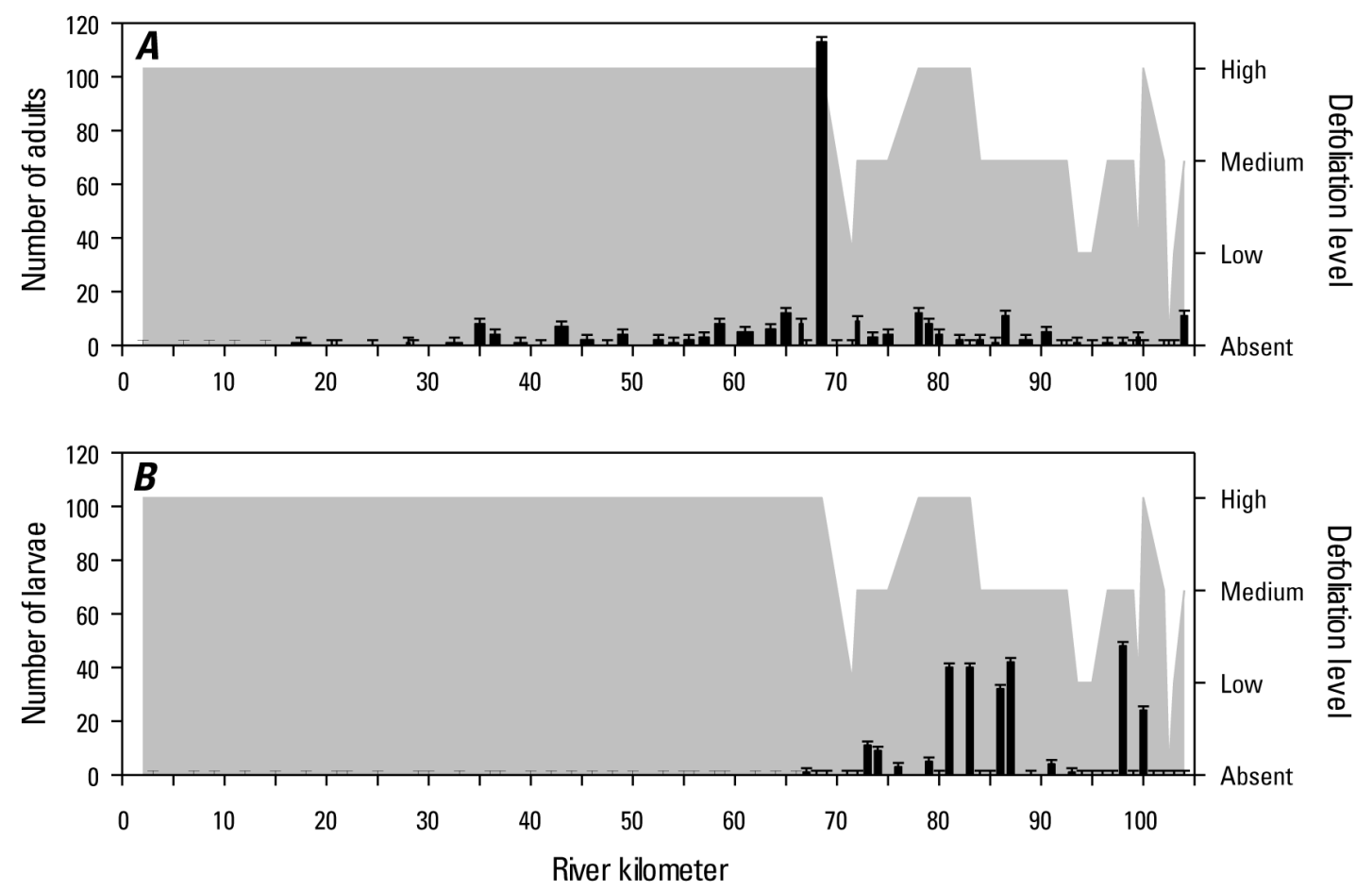

Figure 2. Distribution of Diorhabda carinulata adults ( $A$, black bars) and larvae ( $B$, black bars) and resulting tamarisk defoliation (gray area) along the Dolores River between the confluences of the Colorado River (river kilometer 0) and the San Miguel River (river kilometer 104) in August 2008.

\section{San Juan River}

Defoliation levels-Along the San Juan River in 2010, we found high-defoliation-level zones extending into our study area from upstream and downstream locations (fig. 4). From Bluff, Utah, defoliation levels were consistently 100 percent downriver for $>32 \mathrm{~km}$. From that point downstream, defoliation levels decreased and were mostly low for another $55 \mathrm{~km}$. At $\sim 90$ $\mathrm{km}$ downstream of Bluff, defoliation levels rose moderately for $30 \mathrm{~km}$, then increased to almost 100 percent for another $13 \mathrm{~km}$, at which point our sampling ended at Clay Hills Crossing, Utah. 
Adult beetles - Adult beetles were found at low abundance levels throughout all reaches of the San Juan River in 2010 with the exception of two spikes at km 34 and $\mathrm{km} 133$ downstream of Bluff (fig. 4A). The pattern of adult beetle numbers was consistently low throughout all defoliation zones except for the transition zones where defoliation rates decreased $\left(r^{2}=0.0127\right.$; fig. $4 A$ ).

Beetle larvae - We did not detect any larvae in the $32 \mathrm{~km}$ downstream from Bluff, where tamarisk was 100 percent defoliated, except for one record of 7 individuals $8 \mathrm{~km}$ downriver (fig. $4 B$ ). We then found larger numbers of larvae from $\mathrm{km} 32$ to 117.5 downstream from Bluff; numbers generally peaked between $\mathrm{km} 79$ and 90 downstream (fig. 4B). Numbers of larvae declined markedly at $119 \mathrm{~km}$ downstream from Bluff and few larvae were found from there downriver to Clay Hills Crossing. On the San Juan River, we found little relation between larvae numbers and defoliation rates $\left(r^{2}=0.429\right)$, but the pattern of larvae abundance was generally inverse to defoliation level (fig. $4 B$ ).

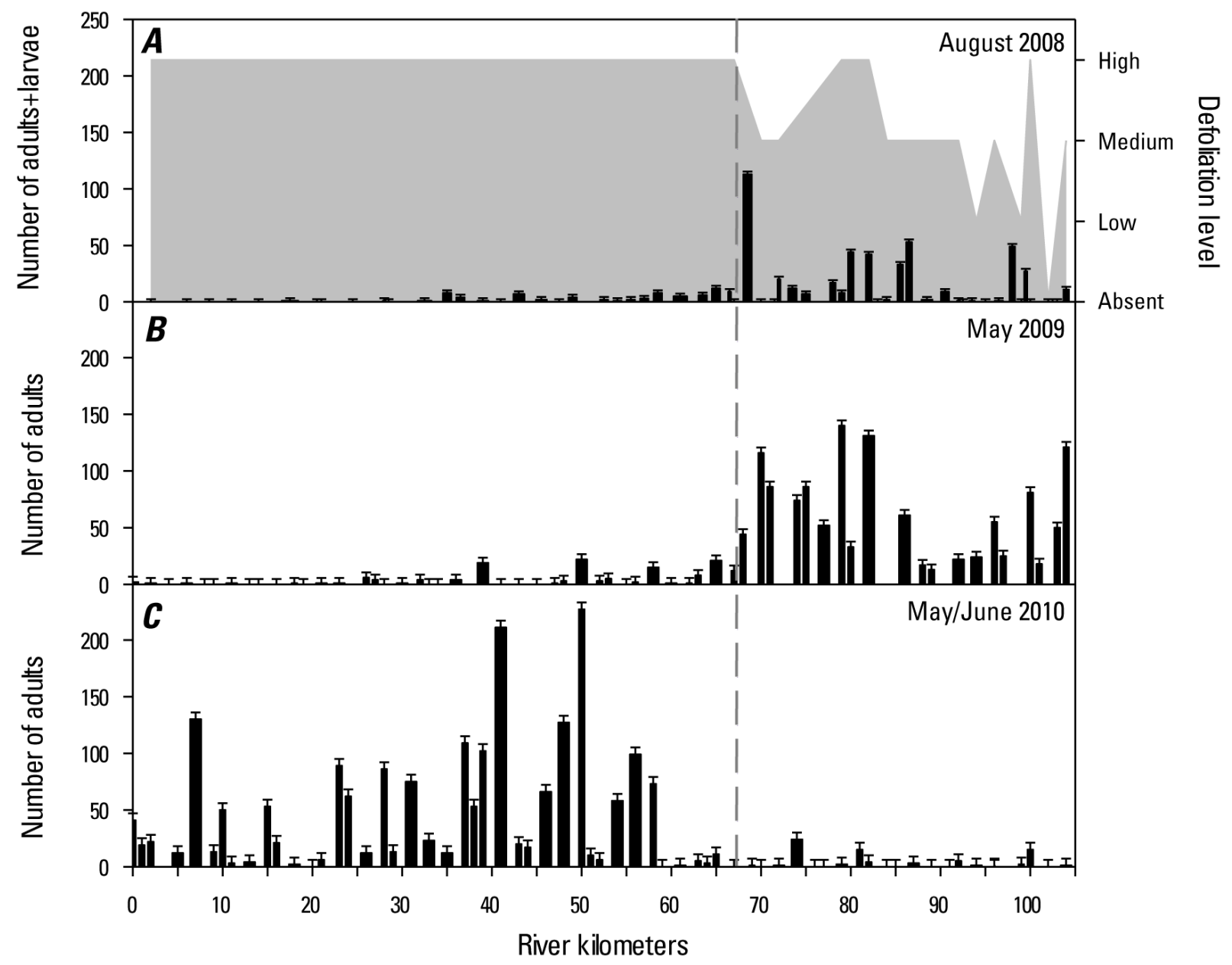

Figure 3. Comparative distributions of Diorhabda carinulata adults (black bars) recorded along the Dolores River in 2008-10. Gray area in $A$ marks tamarisk defoliation. Gray dashed line denotes boundary between areas of cohesive high and moderate defoliation levels in August $2008(A)$. The legacy of this high-defoliation-level zone is visible in the distribution of the adult population in $2009(B)$ and $2010(C)$. 


\section{Discussion}

The patterns of $D$. carinulata abundance and tamarisk defoliation level that we found on the Dolores and San Juan Rivers were largely a product of the locations of initial beetle releases, coupled with the degree of tamarisk defoliation and annual beetle-movement patterns. The $D$. carinulata population introduced at the confluence of the Dolores and Colorado Rivers in 2004 began to expand up the Dolores River in 2006. By early 2008, this population had expanded upriver far enough to assimilate the smaller population introduced in 2006 at the Gateway site, but it had not yet reached Bedrock, Colo. As D. carinulata populations continued to spread in 2008, the first- and second-generation larvae completely defoliated tamarisk from the Colorado River confluence upstream to $\mathrm{km}$ 68.5. After these larvae pupated and reached adulthood, beetles moved upstream to areas where green tamarisk was more available, as we observed adults and new larvae only in areas from km 68.5 to 104 upstream of the Colorado River. Additionally, defoliation was recorded at the Bedrock site (km 156) by July 2008.

At the time of our August 2008 Dolores River survey, $>50$ percent of adult beetles would likely have already begun to enter reproductive diapause, limiting further dispersal and reproduction, and resulting in adult beetles seeking nearby overwintering sites in the leaf litter (Bean and others, 2007a, b; Bean and others, 2012). We infer that the spatial distribution of adults and larvae found in our August 2008 survey was representative of adult beetles that would overwinter that year and emerge from overwintering at that site in spring 2009. In fact, the adults that we recorded in May 2009 were distributed in a pattern similar to that of the adults and larvae that were present in August 2008 (fig. 3). Thus, the first generation of larvae in 2009 likely were also established in the same areas where adult beetles were found in May 2009. As these larvae developed, food resources would have rapidly depleted in that area, eventually forcing the beetle population to emigrate to where green tamarisk foliage was available, such as along the previously abandoned stretch of the Dolores River from $\mathrm{km} 0$ to 60. In May 2010, adult beetles were distributed from $\mathrm{km} 0$ to 60 , with numbers declining in the river stretch upstream. Hultine and others (2010a) described smaller beetle numbers and peak defoliation occurring later in summer 2009 relative to 2008 on the Dolores River, $16 \mathrm{~km}$ upstream from the Colorado River confluence. This observation suggests that beetles emerged from overwintering at that site in 2008 , leading to early defoliation with the first generation of larvae, whereas the smaller numbers of beetles and later defoliation in 2009 were due to gradual immigration of the $D$. carinulata population back to the site later in the summer.

Displacement of the $D$. carinulata population due to resource depletion also occurred on the San Juan River in 2010. The beetle population, expanding from its introduction site in Bluff, Utah, completely used all the tamarisk leaf resources from Bluff to $32 \mathrm{~km}$ downstream (100percent defoliation) and forced emigration to areas farther downriver. Simultaneously, we observed that the population expanding upriver from the Paiute Farms, Utah, introduction site, had heavily defoliated tamarisk from Clay Hills Crossing, Utah, to $13 \mathrm{~km}$ upstream. As this population emigrated farther upriver, it soon converged with the population expanding downriver from Bluff, resulting in complete colonization of the river corridor (fig. 4).

Where $D$. carinulata achieve locally high population densities, we found that they completely defoliate stands of tamarisk and then vacate the area, probably in search of new food resources (that is, green tamarisk leaves). This pattern was consistent at all of our study sites. The high level of tamarisk defoliation along the Dolores River in 2008 and along the San Juan River in 2010 effectively led to the beetles' temporary desertion of those areas, in turn affecting the spatial distribution and colonization patterns of beetle abundance in the future (for example, 
in 2009 and 2010 along the Dolores River). Cossé and others (2005) also found that the ability of this species to reach high population densities, possibly as a result of an aggregation pheromone, can lead to rapid and complete utilization of its food resource, apparently causing emigration of almost the entire resident beetle population after complete tamarisk defoliation. The movement of $D$. carinulata from one segment of a river reach to another has been shown by Nagler and others (2014) on the Virgin River, where they documented an average beetle-colonization distance of 25 river km per year. At all our study sites we determined that this recolonization distance averaged 50 river $\mathrm{km}$ (range, 35-65 km), twice what Nagler and others (2014) determined on the Virgin River.
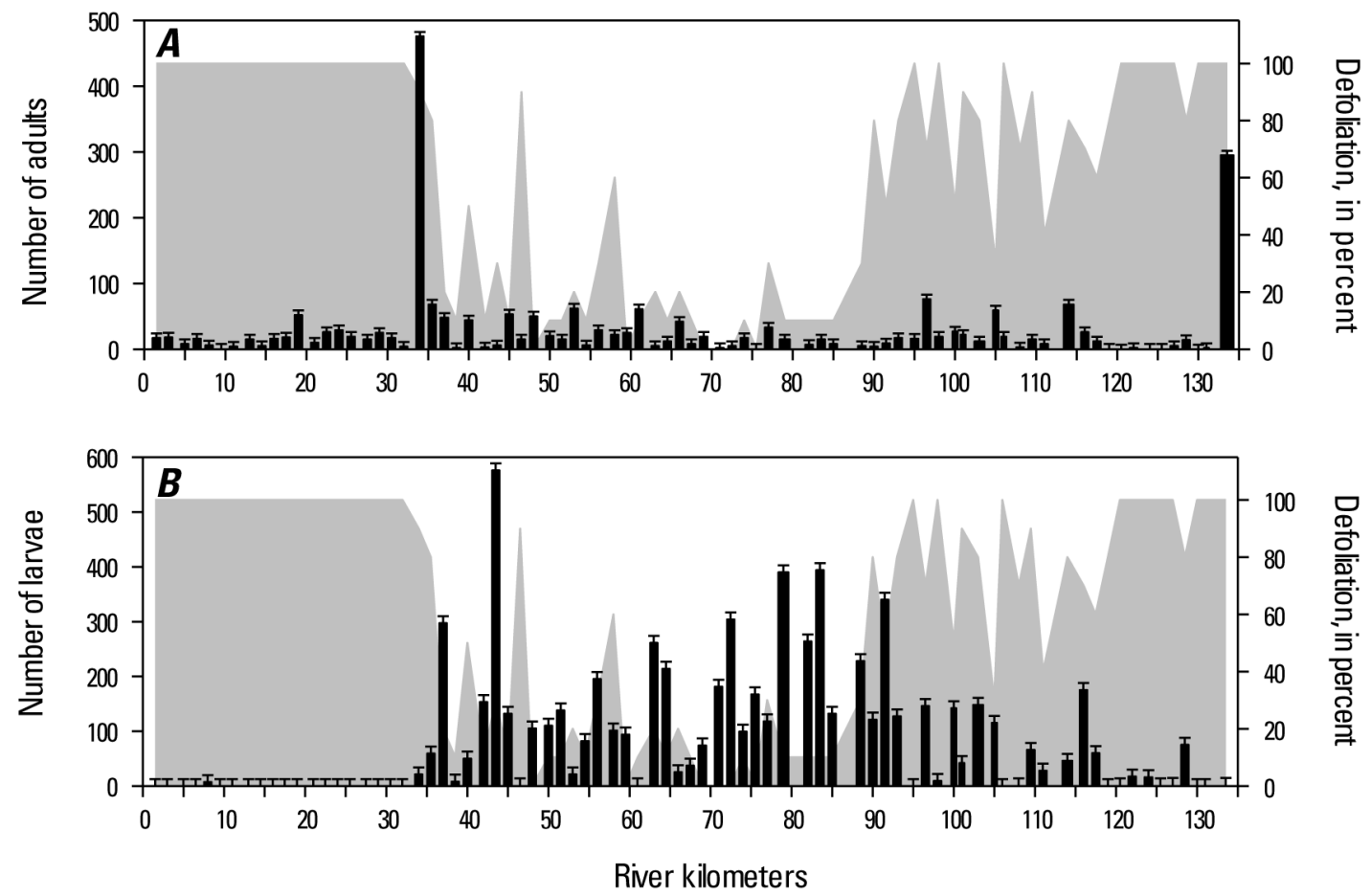

Figure 4. Comparative distributions of Diorhabda carinulata adults ( $A$, black bars) and larvae ( $B$, black bars) and tamarisk defoliation levels (gray area) recorded in late July 2010 along the San Juan River between Bluff, Utah (river kilometer 0), and Clay Hills Crossing, Utah (river kilometer 135).

Spring emergence of overwintering adult $D$. carinulata is linked to temperature, bud burst, and the first appearance of foliage on tamarisk (Lewis and others, 2003). First oviposition by the overwintering generation and the appearance of the first larval generation of the season can be well synchronized in an area when bud burst and temperature rise occur in unison. This synchronization could explain the initial episodic defoliation that Hultine and others (2010a) observed in 2008, when the uniform population emergence owing to temperature rise in spring 2008 led to synchronous establishment of the first larval generation and defoliation of the season, after which adult beetles emigrated out of the site. This pattern explains why, where we found fully green canopies, freshly emerged adult beetles did not need to travel far for food, regardless of the defoliation pattern in the previous year. As the first larval generation grows and feeds, defoliation begins to occur across the colonized area. If the defoliation level becomes intense, mobile adult beetles are forced to emigrate from the defoliated area in search of food resources. Emigration then leads to colonization of new areas and (or) reoccupation of previously 
abandoned areas, as we observed in 2010 from river $\mathrm{km} 0$ to 60 on the Dolores River. Thus, the timing of an area's colonization, the beetle population's capacity to fully defoliate an area, and the extent of the beetle population directly influence the time when a site becomes defoliated within a season and over a period of years. Snyder and others (2012) reported similar results in which large-scale defoliation in 2009 was followed by a near-disappearance of the beetle population in 2010 in a study along the Truckee River in Nevada. Snyder and others reported that the peak $D$. carinulata density in 2010 was half the previous year's peak. Although a latespring freeze earlier that year could have influenced those results, this decrease in density may have been due to large-scale emigration as a result of resource depletion, similar to our findings.

Understanding this pattern of resource depletion and $D$. carinulata population movement are necessary when considering the impact of the beetle on tamarisk habitat and the consequences for other species that live in riparian habitats of the Western United States. For example, the timing of nest building, egg laying, and fledging of bird species may be affected quite differently, depending on when tamarisk defoliation events occur at a site (Sogge and others, 2008; Paxton and others, 2011). If beetles overwinter at a site, that site will be defoliated earlier in the season than where beetles come to occupy midseason after emigrating from another area. Resource managers can take advantage of $D$. carinulata for the suppression of tamarisk, but it is also important to monitor beetle populations to predict the timing of defoliation events. For example, defoliation late in the season, after nesting has occurred, will have less impact on bird species that choose to nest in tamarisk than if defoliation occurs in the middle of the nesting period.

Further studies are necessary to understand the details of this "colonize-defoliateemigrate" cycle and its long-term effects on tamarisk and other plants and animals in Colorado Plateau ecosystems. When considering the mechanism for which areas are abandoned, it is unclear whether high defoliation levels discourage oviposition by adult $D$. carinulata and encourage dispersal, or if adult beetles lay eggs within high-defoliation-level areas but the newly hatched larvae do not survive. Lewis and others (2003) reported much higher mortality in $D$. carinulata neonate larvae when given suboptimal foliage on which to feed. Future studies could elucidate whether adult $D$. carinulata lay eggs independently of defoliation levels. Additionally, future research can focus on the response of tamarisk plants to defoliation by $D$. carinulata.

Tamarisk that is subjected to periodic defoliation may persist, because longer intervals between defoliation events will allow plants to regain lost energy reserves, although it is presently unknown how long this pattern can persist before the tamarisk plant succumbs. Longer term studies would also be useful in understanding the evolving relation among $D$. carinulata, tamarisk, and other plants and animals within the riparian ecosystems of North America as $D$. carinulata move beyond their initial expansion phase.

\section{Conclusion}

D. carinulata populations are continuing to spread rapidly across the Colorado Plateau, by an average rate of at least $50 \mathrm{~km}$ each year along major river corridors. With these increasing beetle populations, more areas are being subjected to partial and complete tamarisk defoliation in which all available tamarisk leaf matter is being consumed, resulting in subsequent large-scale emigration of $D$. carinulata from the completely defoliated areas. Thus, the lack of food (tamarisk leaves) leads to an abandonment of the defoliated area by adult beetles, whereas partially denuded areas retain beetles that overwinter at that site. We found no D. carinulata abandonment of partially defoliated tamarisk areas, although abandonment of completely 
defoliated areas lasted at least a year. Adult beetle movement was also influenced by the seasonal timing of emergence and the timing of emigration in relation to the amount of tamarisk leaves available at a given site. Understanding the extent and densities of $D$. carinulata populations throughout the season will be useful to land managers in predicting when and where these intense defoliation events will occur in the following year. Future studies can use our baseline information to better assess the long-term persistence and stability of $D$. carinulata populations and tamarisk density as $D$. carinulata invasions continue to expand across the Colorado Plateau.

\section{Acknowledgments}

We thank C. Holmes, N. Ament, A. Chandler, S. Eginoire, D. Erickson, J. Lanci, L. Tate, C. Taylor, B. Cooper, and C. Kropp for their help with data collection. M. Johnson, L.

Mackarick, and M. McMaster were crucial in coordinating aspects of this project. T. Higgs and W. Robinson were helpful in providing original tamarisk beetle release-site data. T. Dudley, B. Ochoa, and two anonymous reviewers provided helpful comments on earlier drafts of this chapter. We gratefully acknowledge the support of M. Johnson, D. Bean, R. Dennis, and the Jamison family.

\section{References Cited}

Bartelt, R.J., Cossé, A.A., Zilkowski, B.W., Wiedenmann, R.N., and Raghu, S., 2008, Earlysummer pheromone biology of Gallerucella calariensis and relationship to dispersal and colonization: Biological Control, v. 46, p. 409-416.

Bean, D.W., Dalin, P., and Dudley, T.L., 2012, Evolution of critical day length for diapause induction enables range expansion of Diorhabda carinulata, a biological control agent against tamarisk (Tamarix spp.): Evolutionary Applications, v. 5, no. 5, p. 511-523.

Bean, D.W., Dudley, T.L., and Keller, J.C., 2007a, Seasonal timing of diapause induction limits the effective range of Diorhabda elongata deserticola (Coleoptera: Chrysomelidae) as a biological control agent for tamarisk (Tamarix spp.): Environmental Entomology, v. 36, no. 1, p. $15-25$.

Bean, D.W., Wang, T., Bartelt, R.J., and Zilkowski, B.W., 2007b, Diapause in the leaf beetle Diorhabda elongata (Coleoptera: Chrysomelidae), a biological control agent for tamarisk (Tamarix spp.): Environmental Entomology, v. 36, p. 531-540.

Cossé, A.A., Bartelt, R.J., Zilkowski, B.W., Bean, D.W., and Petroski, R.J., 2005, The aggregation pheromone of Diorhabda elongata, a biological control agent of saltcedar (Tamarix spp.) - Identification of two behaviorally active components: Journal of Chemical Ecology, v. 31, no. 3, p. 657-670.

DeLoach, C.J., Lewis, P.A., Carruthers, R.I., Herr, J.C., Tracy, J.L., and Johnson, J., 2003, Host specificity of a leafbeetle, Diorhabda elongata deserticola (Coleoptera: Chrysomelidae) from Asia, for biological control of saltcedars (Tamarix: Tamaricaceae) in the western United States: Biological Control, v. 22, p. 117-147.

Dudley, T.L. and Bean, D.W., 2012, Tamarisk biocontrol, endangered species risk and resolution of conflict through riparian restoration: BioControl, v. 57, p. 331-347.

Friedman, J.M., Auble, G.T., Shafroth, P.B., Scott, M.L. Merigliano, M.F., Freehling, M.D., and Griffin, E.R., 2005, Dominance of non-native riparian trees in western USA: Biological Invasions, v. 7, p. 747-751. 
Hudgeons, J.L., Knutson, A.E., DeLoach, C.J., Heinz, K.M., McGinty, W.A. and Tracy, J.L., 2007a, Establishment and biological success of Diorhabda elongata elongata on invasive Tamarix in Texas: Southwestern Entomologist, v. 32, no. 3, p. 157-168.

Hudgeons, J.L., Knutson, A.E., Heinz, K.M., DeLoach, C.J., Dudley, T.L., Pattison, R.R., and Kiniry, J.R., 2007b, Defoliation by introduced Diorhabda elongata leaf beetles (Coleoptera: Chrysomelidae) reduces carbohydrate reserves and regrowth of Tamarix (Tamaricaceae):

Biological Control, v. 43, p. 213-221.

Hultine, K.R., Belnap, J., van Riper, C., III, Ehleringer, J.R., Dennison, P.E., Lee, M.E., Nagler, P.L., Snyder, K.A., Uselman, S.M., and West, J.B., 2010a, Tamarisk biocontrol in the western United States-Ecological and societal implications: Frontiers in Ecology and the Environment, v. 8, p. 467-474.

Hultine, K.R., Nagler, P.L., Morino, K., Bush, S.E., Burtch, K.G., Dennison, P.E., Glenn, E.P., Ehleringer, J.R., 2010b, Sap flux-scaled transpiration by tamarisk (Tamarix spp.) before, during, and after episodic defoliation by the saltcedar leaf beetle (Diorhabda carinulata): Agriculture and Forest Meteorology, v. 150, p. 1467-1475.

Lewis, P.A., DeLoach, C.J., Knutson, A.E., Tracy, J.L. and Robbins, T.O., 2003, Biology of Diorhabda elongata deserticola (Coleoptera: Chrysomelidae), an Asian leaf beetle for biological control of saltcedars (Tamarix spp.) in the United States: Biological Control, v. 27, p. 101-116.

Meng, R., Dennison, P.E., Jamison, L.R., van Riper, C., III, Nagler, P., Hultine, K.R., Bean, D.W., and Dudley, T., 2012, Detection of tamarisk defoliation by the northern tamarisk beetle based on multitemporal Landsat 5 Thematic Mapper imagery: GIScience \& Remote Sensing, v. 49, no. 4, p. 510-537.

Nagler, P.L., Pearlstein, S., Glenn, E.P., Brown, T.B., Bateman, H.L., Bean, D.W., and Hultine, K.R., 2014, Rapid dispersal of saltcedar (Tamarix spp.) biocontrol beetles (Diorhabda carinulata) on a desert river detected by phenocams, MODIS Imagery and Ground Observations: Remote Sensing of Environment, v. 140, p. 206-219.

Paxton, E.H., Theimer, T.C. and Sogge, M.K., 2011, Tamarisk biocontrol using tamarisk beetles-Potential consequences for riparian birds in the Southwestern United States: The Condor, v. 113, no. 2, p. 255-265.

Snyder, K.A., Scott, R.L., and McGwire, K., 2012, Multiple year effects of a biological control agent (Diorhabda carinulata) on Tamarix (saltcedar) ecosystem exchanges of carbon dioxide and water: Agricultural and Forest Meteorology, v. 164, p. 161-169.

Sogge, M.K., Sferra, S.J., and Paxton, E.H., 2008, Tamarix as habitat for birds-Implications for riparian restoration in the Southwestern United States: Restoration Ecology, v. 16, no. 1, p. $146-154$.

van Riper, C., III, Paxton, K., O’Brien, C., Shafroth, P., and McGrath, L., 2008, Rethinking avian response to tamarisk on the Lower Colorado River-A threshold hypothesis: Restoration Ecology, v. 16, p. 155-67. 


\title{
Chapter 2. Utilizing Temperature, Day Length, and Diorhabda carinulata Geographic Distribution for Predicting the Intensity of Tamarix Species Defoliation
}

\begin{abstract}
We have investigated the spatial dynamics and timing of defoliation of tamarisk (Tamarix spp.) by the biological control agent Diorhabda carinulata at three sites along the Colorado River and its tributaries. We determined that the location and timing of defoliation were predictable on the basis of (1) abiotic cues for D. carinulata activity, (2) spatial distributions and abundances of $D$. carinulata across each study site, and (3) movement of $D$. carinulata as a result of available tamarisk foliage. We found that average spring temperatures $>15{ }^{\circ} \mathrm{C}$ related to how soon $D$. carinulata began reproducing and defoliation occurred at a study site, leading to variations in voltinism rates of $D$. carinulata. The critical day length for inducing diapause in $D$. carinulata at our study sites was 33-47 minutes shorter than that of populations first released in North America in 2001, suggesting adaptation in response to abiotic cues. We noted a significant positive correlation between the spatial distributions of $D$. carinulata populations in the fall and those of the first generation of larvae in the next spring, suggesting that the areas of defoliation as a result of abundant larval populations could be predicted in advance. We found a significant decrease in $D$. carinulata populations in areas that were 50 -percent defoliated relative to those that were 100-percent defoliated, indicating that D. carinulata will abandon areas once defoliation levels become high. We also measured that the main D. carinulata population area at one study site grew by $19.3 \pm 5.6$ kilometers $(\mathrm{km})$ and that the overall range of this population at that study site grew by $62.8 \pm 5.6 \mathrm{~km}$ over 1 year along a linear riparian corridor. These results will enable conservationists to better understand the timing of defoliation events across a landscape and provide a rationale to forecast tamarisk defoliation in areas colonized by $D$. carinulata.
\end{abstract}

\section{Introduction}

Conflicts between differing management strategies are a common source of challenges in the conservation of natural environments (Dunwiddie and others, 2016). The management of nonnative and invasive tamarisk (Tamarix spp.) trees in North America has many such challenges (Shafroth and others, 2005; Shafroth and Briggs 2008; Dudley and Bean, 2012). Tamarisk, now one of the most widespread riparian trees in the Western United States (Friedman and others, 2005), has invaded many riparian systems across western North America (Di Tomaso, 1998). In an effort to control tamarisk in the United States, a leaf beetle was introduced in 2001 as a biological control agent (Lewis and others, 2003). Since its release, the biocontrol agent Diorhabda spp. (tamarisk beetle) has spread rapidly across much of the Western United States and Mexico (Meng and others, 2012; Jamison and others, 2015; Sanchez-Peña Celso Morales-Reyes and others, 2016), defoliating tamarisk and causing extensive tree mortality (Hultine and others, 2015). Since the release of Diorhabda spp., concern has been expressed regarding the impact that tamarisk defoliation will have on wildlife that use tamarisk. Much of this concern has focused on the impact to breeding bird habitat (van Riper and others, 2008), specifically that of Empidonax traillii extimus (Southwestern Willow Flycatcher; Sogge and others, 2008; Paxton and others, 2011; Dudley and Bean, 2012). A Federally listed endangered 
bird, the Southwestern Willow Flycatcher has been documented to use tamarisk as a nesting substrate (Brown and Trosset, 1989), leaving nests at risk to elevated temperatures, decreased feeding of nestlings, and depredation if defoliation occurs during the breeding season (Sogge and others, 2008; Paxton and others, 2011; Peterson and others, 2015). The effectiveness and low cost associated with using Diorhabda spp. as a control agent may highlight it as one of the most economical and sustainable mechanisms for controlling tamarisk at a landscape level (Shafroth and others, 2005). The challenge to utilizing Diorhabda spp., however, lies in the inability to control the timing and extent of defoliation events, leaving associated organisms such as the Southwestern Willow Flycatcher at risk of being affected during times of significant life-history events (for example, breeding). With sufficient data on the spatial distribution of Diorhabda spp. populations and knowledge of its phenology, the timing of defoliation events may be predictable across a given landscape. If so, such knowledge would allow restoration practitioners to be better informed for making decisions about contrasting conservation and restoration goals.

The ability to predict the seasonal timing of tamarisk defoliation across a given landscape has not yet been demonstrated, even with multiple studies on the phenology of Diorhabda spp. (Herrera and others, 2005; Bean and others, 2007a, b; Dalin and others, 2010) and the large amounts of Diorhabda spp. distribution data currently being gathered (Sanchez-Peña Celso Morales-Reyes and others, 2016; http://www.tamariskcoalition.org/programs/tamarisk-beetlemaps). The phenologic cycle of Diorhabda spp. begins with adult beetles arising from leaf litter in the spring after overwintering, by which time feeding on tamarisk and reproduction soon commence. Emergence from overwintering is likely cued by warmer temperatures, after completion of reproductive diapause by midwinter, like other Chrysomelid beetles (Lewis and others, 2003; Dalin, 2011). As larvae of the first summer generation emerge, they begin to feed on tamarisk foliage, leading to leaf desiccation (Snyder and others, 2010). When larval abundances are high, complete defoliation of a tree's canopy can occur (Dudley and others, 2012). Larval population abundances large enough to defoliate tens of kilometers of river banks have been observed in many regions across Southwestern North America since the introduction of Diorhabda spp. in 2001 (Lewis and others, 2003; Meng and others, 2012; Jamison and others, 2015). In North America, Diorhabda spp. go through two to six generations before photoperiod cues in the late summer induce diapause (Lewis and others, 2003; Bean and others, 2007b; Milbrath and others, 2007; Dalin and others, 2010). Once in diapause, Diorhabda spp. cease to reproduce and disperse, and crawl into the leaf litter to overwinter (Lewis and others, 2003; Bean and others, 2007b). Jamison and others (2015) noted that populations of Diorhabda carinulata (northern tamarisk beetle) abandoned areas with high defoliation levels and that the spatial distribution of a beetle population in the fall was similar to that in the following spring. Thus, overconsumption of resources may drive the spatial dynamics of Diorhabda spp. populations, whereas environmental cues may dictate seasonal timing and duration.

We decided to investigate how $D$. carinulata biology and the use of its resources affect the timing of defoliation events throughout the year across a broad landscape. Specifically, we sought to determine whether the timing of defoliation events could be predicted by the phenology, abundance, and spatial dynamics of $D$. carinulata. To this end, we monitored three sites of actively colonizing $D$. carinulata populations: one site along the San Juan River and two sites along the Colorado River downstream of Lees Ferry, Ariz. The sites are aligned along an elevational gradient (leading to a temperature cline) within the narrow latitude range $\sim 35^{\circ} 55^{\prime}-$ $36^{\circ} 50^{\prime} \mathrm{N}$ (maintaining similar annual day lengths). We monitored each population for a year (spring to spring), recording beetle populations, tamarisk defoliation levels, and the spatial 
distribution of each beetle population monthly throughout the active season. We intended to document how $D$. carinulata abundances, spatial dynamics, and phenologic cues determined defoliation events within and between years by looking specifically at (1) how abiotic factors affected the timing and duration of summer activity (including defoliation), as well as affected growth rates; and (2) how the spatial distribution of $D$. carinulata dictated the extent of defoliation, while simultaneously being influenced by degradation of its food resource. Our goals were to determine whether environmental cues affecting the phenology of $D$. carinulata could predict the timing of defoliation and whether spatial dynamics as a result of resource availability predicted the extent of defoliation, within the year and across a landscape.

\section{Methods}

\section{Study Sites}

We chose three sites at which to conduct our study: the Grand Canyon and Marble Canyon segments of the Colorado River and a segment of the San Juan River (fig. 5). Each study site had $D$. carinulata populations that recently had begun to colonize tamarisk and the length of the river segments at each site varied between 86 and $238 \mathrm{~km}$. Variations in site length were due to logistical constraints and collaborations with associated monitoring programs. The Grand Canyon study site covered $238 \mathrm{~km}$ of the Colorado River, from $\sim 16 \mathrm{~km}$ upstream from Phantom Ranch, Arizona, at Hance Rapids to Diamond Creek downstream. The Grand Canyon study site (lat $35^{\circ} 45^{\prime}-36^{\circ} 23^{\prime} \mathrm{N}$ ) was the lowest elevation (400-750 meters [m] elev) and warmest. The Marble Canyon study site was located along $123 \mathrm{~km}$ of the Colorado River, from the boat ramp at Lees Ferry, Ariz., downstream to Hance Rapids (upstream boundary of the Grand Canyon study site). The Marble Canyon study site (lat $36^{\circ} 03^{\prime}-36^{\circ} 52^{\prime} \mathrm{N}$ ) is slightly higher in elevation (800-950 m elev) and had slightly cooler temperatures than the Grand Canyon study site. The San Juan study site was located along $86 \mathrm{~km}$ of the San Juan River, from $3 \mathrm{~km}$ from the base of Navajo Dam in New Mexico downstream to the boat ramp at Kirtland, N. Mex. The San Juan study site (lat $36^{\circ} 40^{\prime}-36^{\circ} 49^{\prime} \mathrm{N}$ ) had the highest elevation $(1,600-1,700 \mathrm{~m}$ elev) and coolest temperatures.

Riparian forests at the San Juan study site were largely composed of thick Eleagnus angustifolia (Russian olive) stands, with interspersed patches of tamarisk and varying extents of largely open Populus deltoides (cottonwood) galleries, along a wide alluvial plain. Both the Marble Canyon and Grand Canyon study sites are located within deep, confined bedrock canyons (300-1,000 m wide) and are composed of patchy thickets of mostly Baccharis spp., Pluchea serica (arrowweed), and tamarisk.

\section{Field Methodology}

We accessed study sites by raft or kayak and carried out sampling at 1.6- to $4.8-\mathrm{km}$ intervals, depending on the season (winter or summer) and logistical constraints. During the summer months (April-September), we sought to sample at 1.6-km intervals along the river corridor, although logistical issues during each trip sometimes led to sampling at 3.22- to $4.8-\mathrm{km}$ intervals. Each sample included 25 1-m-wide sweeps with a 39-cm-diameter sweep net across five tamarisk canopies. The total numbers of captured $D$. carinulata adults, early-instar larvae, and late-instar larvae (differentiated by the presence of a yellow lateral stripe) were recorded. In addition to sweep samples, one 30-second visual search was made in the tamarisk canopy per sample, in which the number of $D$. carinulata egg clusters were counted. Additionally, the 
average defoliation level for the general sampling area $\left(\sim 0.25\right.$ square kilometers, $\left.\mathrm{km}^{2}\right)$ was recorded in 10-percent increments, with 100-percent defoliation equating to the total destruction of all green tamarisk leaves within the sampling area. No sweep netting was done during winter trips (November and February) when beetles were inactive; instead, we collected five 50-gram soil samples of leaf litter with a shovel $\sim 5 \mathrm{~m}$ apart under the tamarisk canopies in each sampling area. Collections were spread out on a $12 \times 24$-inch tray onsite, and the total number of alive and dead D. carinulata adults were counted. In winter, we sampled at 4.8-km intervals along each river.

Beginning in May 2011 (Marble Canyon and Grand Canyon) and June 2011 (San Juan), we sampled at all three study sites monthly through September, when D. carinulata reproduction ended. We conducted one winter trip at each study site in winter 2011-12 (November 2011 for Marble Canyon and Grand Canyon and February 2012 for San Juan) to assess the spatial distribution and condition of overwintering D. carinulata. In 2012, we visited all three sites one month earlier than in 2011, and twice over two consecutive months, to assess overwintering emergence and establishment of the first summer generation (in April and May for Marble Canyon and Grand Canyon and in May and June for San Juan).

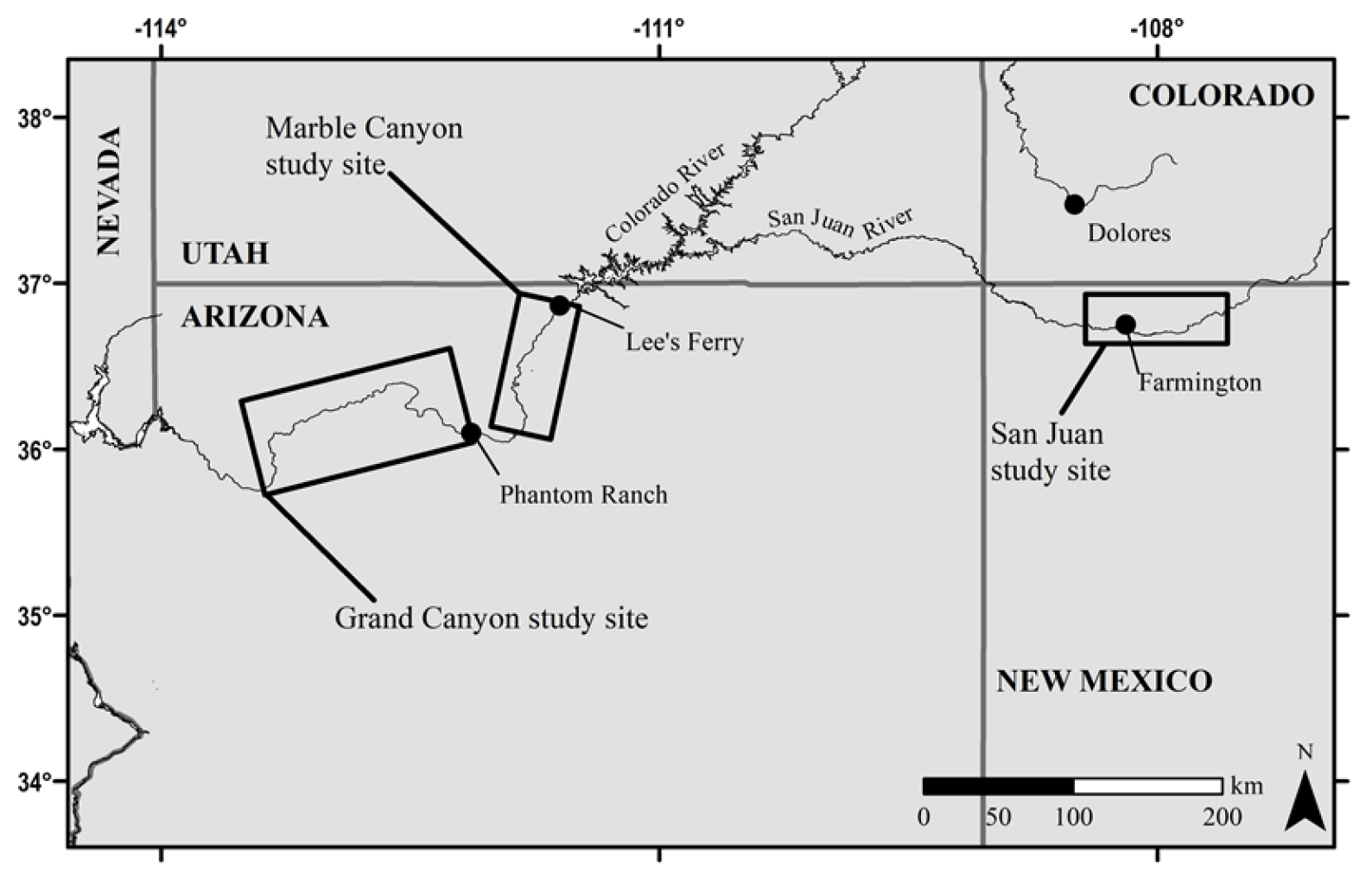

Figure 5. Map of the Colorado and San Juan Rivers in Arizona and New Mexico showing study site locations. All three study sites are located within a similar latitude and along an east-west elevational cline.

\section{Data Analysis}

To avoid issues with spatial extent and type I error (Turner and others, 1989), we excluded all sample data from outside the determined $D$. carinulata population range at each study site. The population range was determined to extend across all sample blocks occupied by the main population body within our site boundaries outward (either upstream or downstream) to 
the farthest recorded $D$. carinulata observed away from the population during the timeframe of our study. We excluded the area of each study site beyond the farthest recorded $D$. carinulata from our analyses because we considered it too far away from the beetle population to be colonized for the time period of our study. Thus, we analyzed only data from Lees Ferry, Ariz. (km 0), downstream to Nevills Rapid (km 121) at the Marble Canyon study site, and from just below Phantom Ranch, Ariz. (km 145), to Pumpkin Springs (km 343) at the Grand Canyon study site. We observed $D$. carinulata spread across the entire sampling area at the San Juan study site, and so no sample data were excluded.

Because logistical constraints led to some variation in our sampling scheme, we binned and averaged our data in 4.8-km (that is, $3 \mathrm{mi}$ ) intervals for use in comparing the spatial distributions of $D$. carinulata, beginning with the farthest upstream sampling location at each study site. These averaged sampling blocks were then used for spatial comparisons in linear and polynomial regressions. For analysis of population statistics (for example, mean life stage numbers), we used only raw, unbinned data as input, ANOVA and T-tests to compare the means, and a critical $p$-value of $p<0.05$ to infer significance of results.

We used the temperature-specific developmental ranges reported in Herrera and others (2005) to estimate the number of $D$. carinulata generations produced at each study site. To do so, we compared Herrera and others' (2005) developmental days with the mean monthly temperature for each survey period, the number of days between surveys, and the life stage(s) in the majority per survey. We used the percentage of samples occupied by D. carinulata with eggs to gauge reproduction per survey trip.

To estimate the critical day length for diapause induction, we assumed that 50 percent of the population would enter diapause 13 days after the critical day length (Bean and others, 2007a), and that eggs would stay viable for about a week at our sites in August, depending on temperature (7 days in San Juan and 5 days in Marble Canyon and Grand Canyon). We assumed that population-wide diapause had occurred when the percentage of samples with eggs present decreased to zero.

To gauge $D$. carinulata population growth, we delineated the spatial distribution of each population into one of two categories: (1) the main population body and (2) the dispersal zone. The main population body was the proportion of the area with cohesively high numbers of $D$. carinulata (in all life stages); we delineated its boundary as between the last sample block toward the outer edge of the population in which $D$. carinulata numbers were $\geq 10$ and the previous sample block before occupation. The dispersal zone began at the next sample block after the end of the main population body and ended at the last sample block with $D$. carinulata that had no more than two unoccupied sample blocks between it and the previous occupied sample block (fig. 6).

Data on daily temperatures and day lengths at each study site are detailed in appendix 1. 


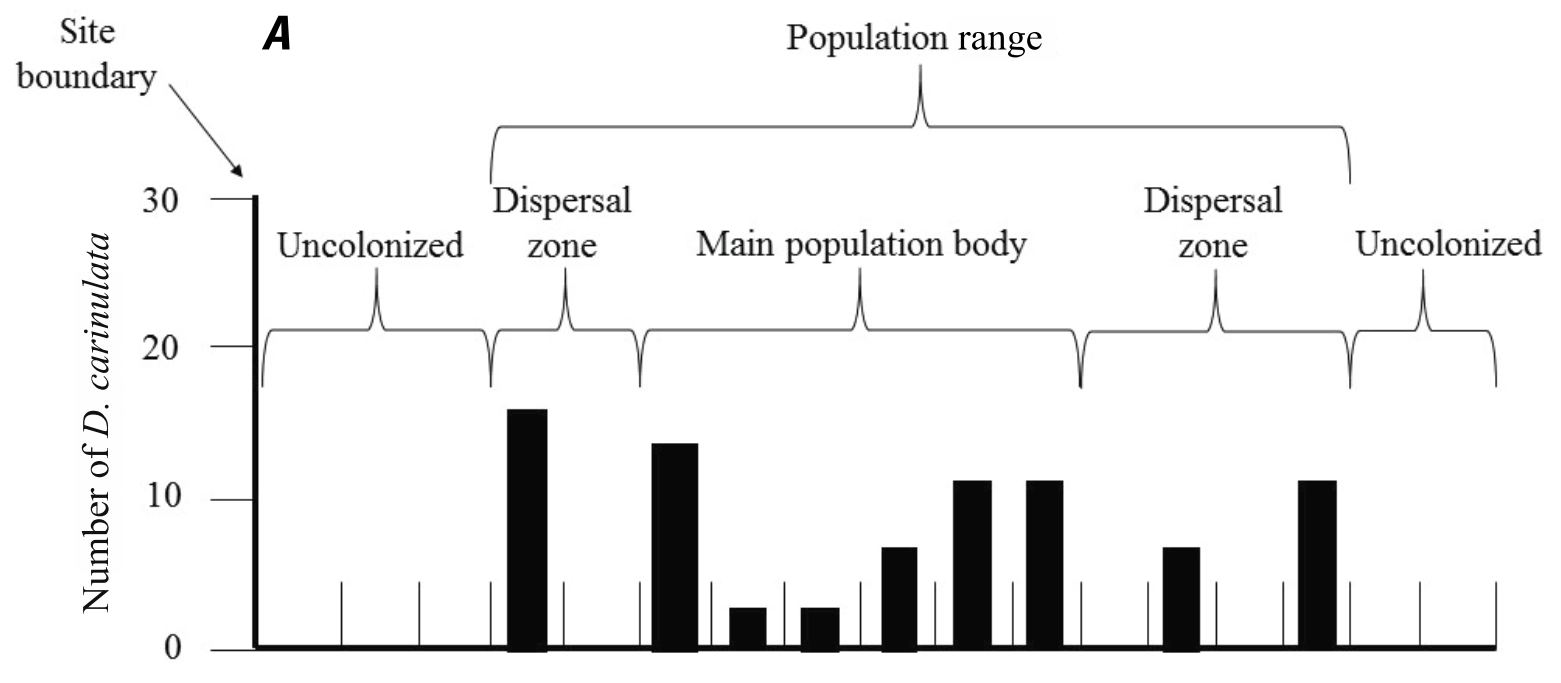

River kilometer

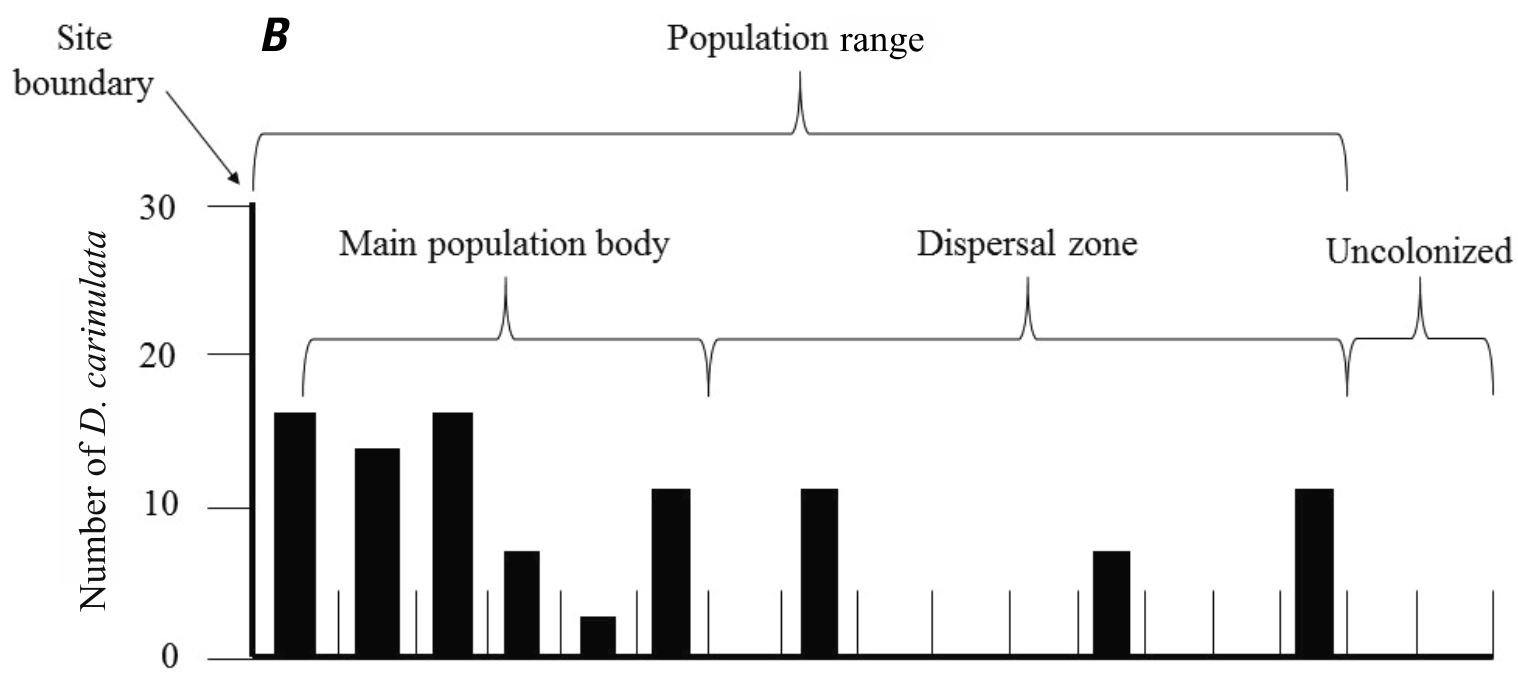

River kilometer

Figure 6. Diorhabda carinulata population distributions in 2011 at the $(A)$ San Juan and $(B)$ Marble Canyon study sites. The total area of the main beetle population, the dispersal zone, and uncolonized regions illustrate how population boundaries are defined within the study sites.

\section{Results}

\section{Influence of Abiotic Cues on Seasonal Timing}

We determined that $D$. carinulata reproduction began at each site in spring and was associated with rising 7-day-averaged air temperatures of $16-24^{\circ} \mathrm{C}$ (fig. 7). We estimated that initial population oviposition ranged from April to June at all study sites in both years (fig. 7) and that population-wide oviposition began $\sim 2$ weeks earlier in 2012 than in 2011 (fig. 7, table 
1). We determined that the timing of initial defoliation varied across our three study sites in relation to the timing of initial reproduction (fig. 8).

Reproductive activity ceased at all three study sites by September, as indicated by the absence of eggs (table 1). We estimate that the critical day length that would lead $>50$ percent of the $D$. carinulata population to enter diapause 13 days later (Bean and others, 2007a) was between 13 hours 52 minutes and 14 hours 6 minutes at the three study sites, for two reasons. First, $>50$ percent of the population had ceased reproducing at the Grand Canyon study site before our August 17-23 surveys, as evidenced by the absence of eggs in samples occupied by D. carinulata. Thus, the critical day length would have occurred at least 13 days before August 17 at the Grand Canyon study site, when day lengths were 13 hours 52 minutes. Second, our last survey trip, during which we observed no change in the number of sites occupied by $D$. carinulata with eggs, was at the Marble Canyon study site from August 10-16. Recognizing that eggs stay viable for 5 days at $30^{\circ} \mathrm{C}$ (mean temperature at the Grand Canyon for those dates was $33^{\circ} \mathrm{C}$; Herrera and others, 2005), we deduce that 100 percent of the population had not entered diapause by at least August 11 (5 days earlier than the last date of our surveys) and so, the critical day length would have to be less than that determined 13 days earlier at the Marble Canyon study site (14 hours 6 minutes). Owing to the range in day lengths based on latitudes across our study area, we concur that the date range in 2011 within which $>50$ percent of each beetle population would have been in diapause would have been between August 9 and 19 .

Because of the differences in the timing of initial oviposition at each study site in spring and the synchronous cessation of reproduction by September, each study site differed in the total duration of summer activity in 2011, limiting the number of new summer generations of $D$. carinulata to two at the San Juan study site and to three at the Marble Canyon and Grand Canyon study sites (table 1). 
Table 1. Diorhabda carinulata population per sampling period at the San Juan, Marble Canyon, and Grand Canyon study sites.

[Abundances for each life stage are from the sum of all samples per survey period; percentage of the total of all life stages is in parentheses. Egg values are the percentage of samples with $D$. carinulata present in which eggs were found. $\mathrm{OW}=$ overwintering beetles]

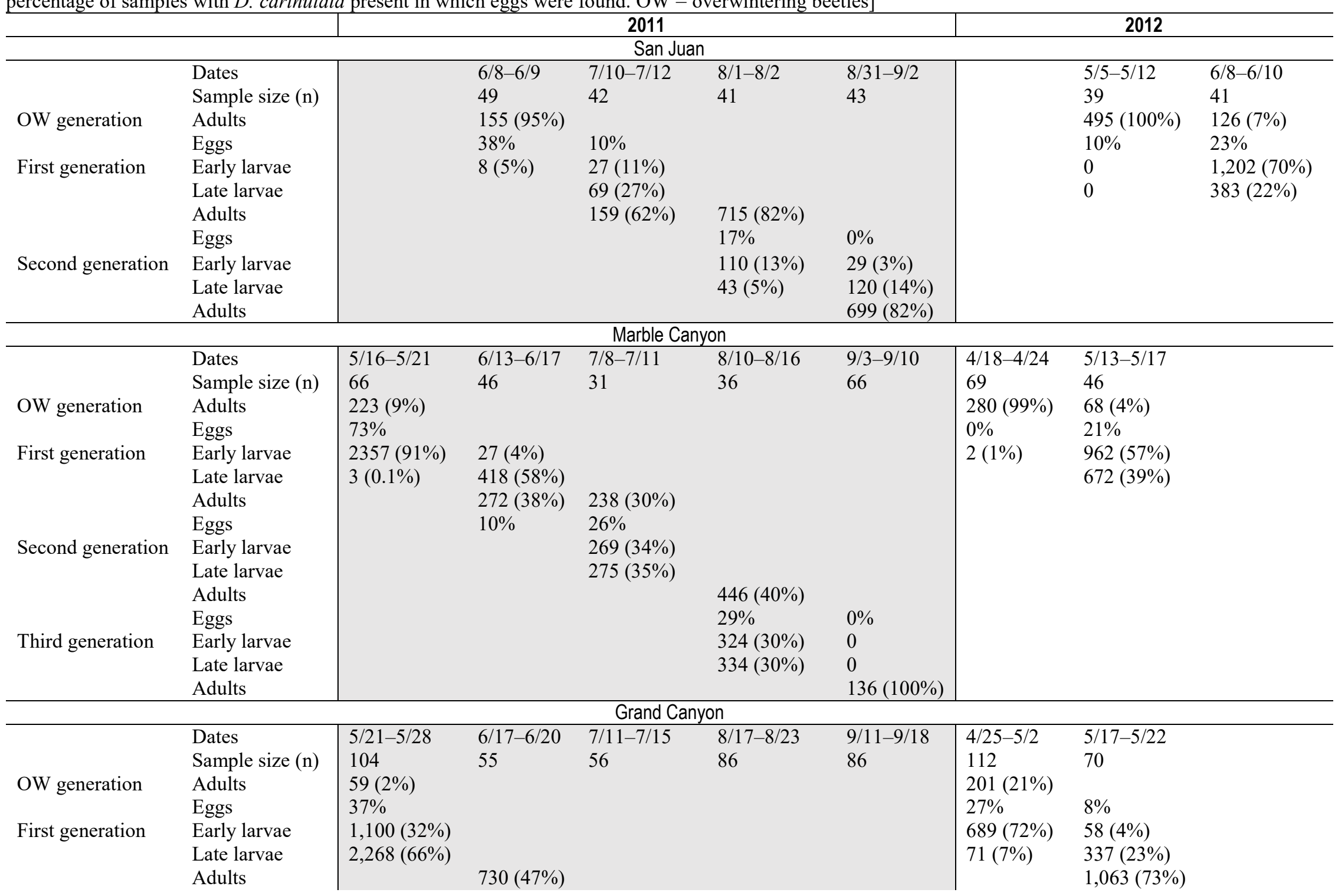




\begin{tabular}{|c|c|c|c|c|c|c|}
\hline \multicolumn{6}{|c|}{2011} & 2012 \\
\hline \multicolumn{7}{|c|}{ Grand Canyon } \\
\hline \multirow{3}{*}{ Second generation } & Eggs & $38 \%$ & \multirow{2}{*}{\multicolumn{3}{|c|}{$221(12 \%)$}} & \\
\hline & Early larvae & $754(49 \%)$ & & & & \\
\hline & Late larvae & $64(4 \%)$ & \multicolumn{3}{|l|}{$229(12 \%)$} & \\
\hline \multirow{5}{*}{ Third generation } & Adults & & \multicolumn{3}{|l|}{$1,435(76 \%)$} & \\
\hline & Eggs & & $37 \%$ & $3 \%$ & $0 \%$ & \\
\hline & Early larvae & & & $208(12 \%)$ & $1(5 \%)$ & \\
\hline & Late larvae & & & $316(18 \%)$ & $1(5 \%)$ & \\
\hline & Adults & & & $1,272(70 \%)$ & $20(90 \%)$ & \\
\hline
\end{tabular}



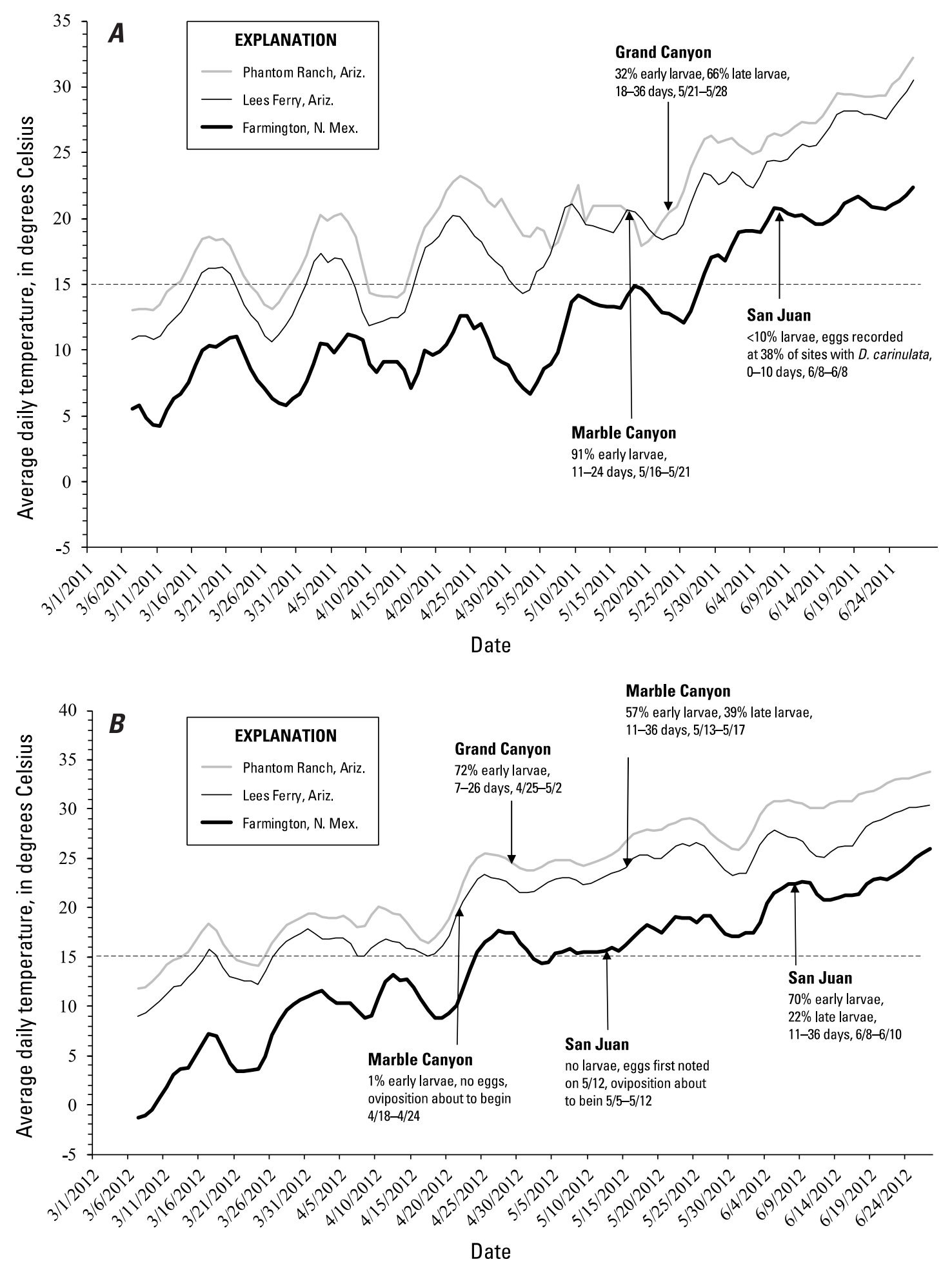

Figure 7. Average daily temperatures at study sites in the Colorado River basin, with timing of initial reproductive activity in $2011(A)$ and $2012(B)$. Arrows denote sampling trips, with percentage of population in a larval stage presented along with estimated number of days since initial population-wide oviposition and dates of survey trip, respectively. Developmental day estimates are based on data of Herrera and others (2005). 


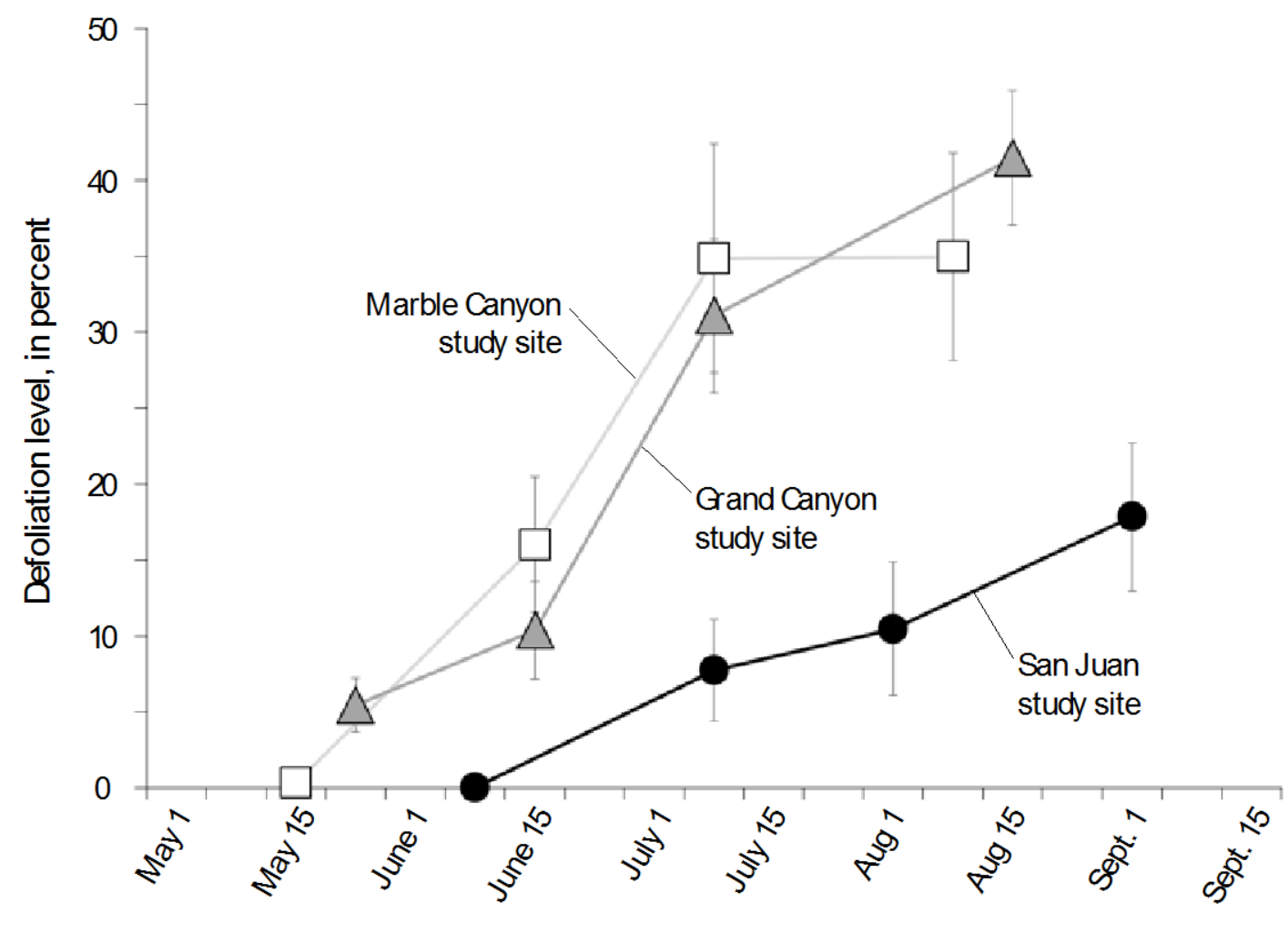

Date in 2011

Figure 8. Mean defoliation levels at the Marble Canyon (white squares), Grand Canyon (gray triangles), and San Juan (black circles) study sites in the Colorado River basin in 2011.

\section{Spatial Dynamics of $D$. carinulata and Defoliation}

We found a significant positive correlation between the distribution of the entire $D$. carinulata population in fall 2011 and spring 2012 at all three study sites (San Juan: June $\times$ September $r^{2}=0.25, p<0.05$; Marble Canyon: May $\times$ August, $r^{2}=0.33, p<0.05$; Grand Canyon: April $\times$ August, $r^{2}=0.14, p<0.05$; fig. 9). The distribution of first-summer-generation larvae in 2012 also significantly correlated with the distribution of the populations of larvae and adult beetles in the previous fall before overwintering (San Juan: June larvae $\times$ (September adults + larvae), $r^{2}=0.22, p<0.05$; Marble Canyon: May larvae $\times$ (August adults + larvae), $r^{2}=0.27, p$ $<0.05$; Grand Canyon: April larvae $\times$ (August adults + larvae), $r^{2}=0.12, p<0.05$ ).

We noted significant positive linear correlation between the relative abundances of firstgeneration larvae and defoliation levels 1 month later at all three of our study sites (Marble Canyon: June defoliation $\times$ May larvae, $r^{2}=0.629, p<0.001$ and July defoliation $\times$ June larvae, $r^{2}=0.190, p<0.042$; Grand Canyon: June defoliation $\times$ May larvae, $r^{2}=0.329, p<0.05$; San Juan: July defoliation $\times$ June larvae, $r^{2}=0.714, p<0.05$ and August defoliation $\times$ July larvae, $r^{2}$ $=0.689, p<0.05$; fig. 10). The relation between $D$. carinulata population and midsummer defoliation level was better fitted to a quadratic bell curve, where $D$. carinulata larvae and adult beetles became less abundant at defoliation levels $>50$ percent (fig. 11). The mean number of larvae per sample with 100-percent defoliation was $0.42 \pm 0.16$ ( 1 standard deviation, $\sigma$ ), and the mean number of larvae per sample with 50-percent defoliation was $46 \pm 16.61(1 \sigma)$. All sample blocks with $>90$ percent defoliation were devoid of larvae during the defoliation period (fig. 12). 

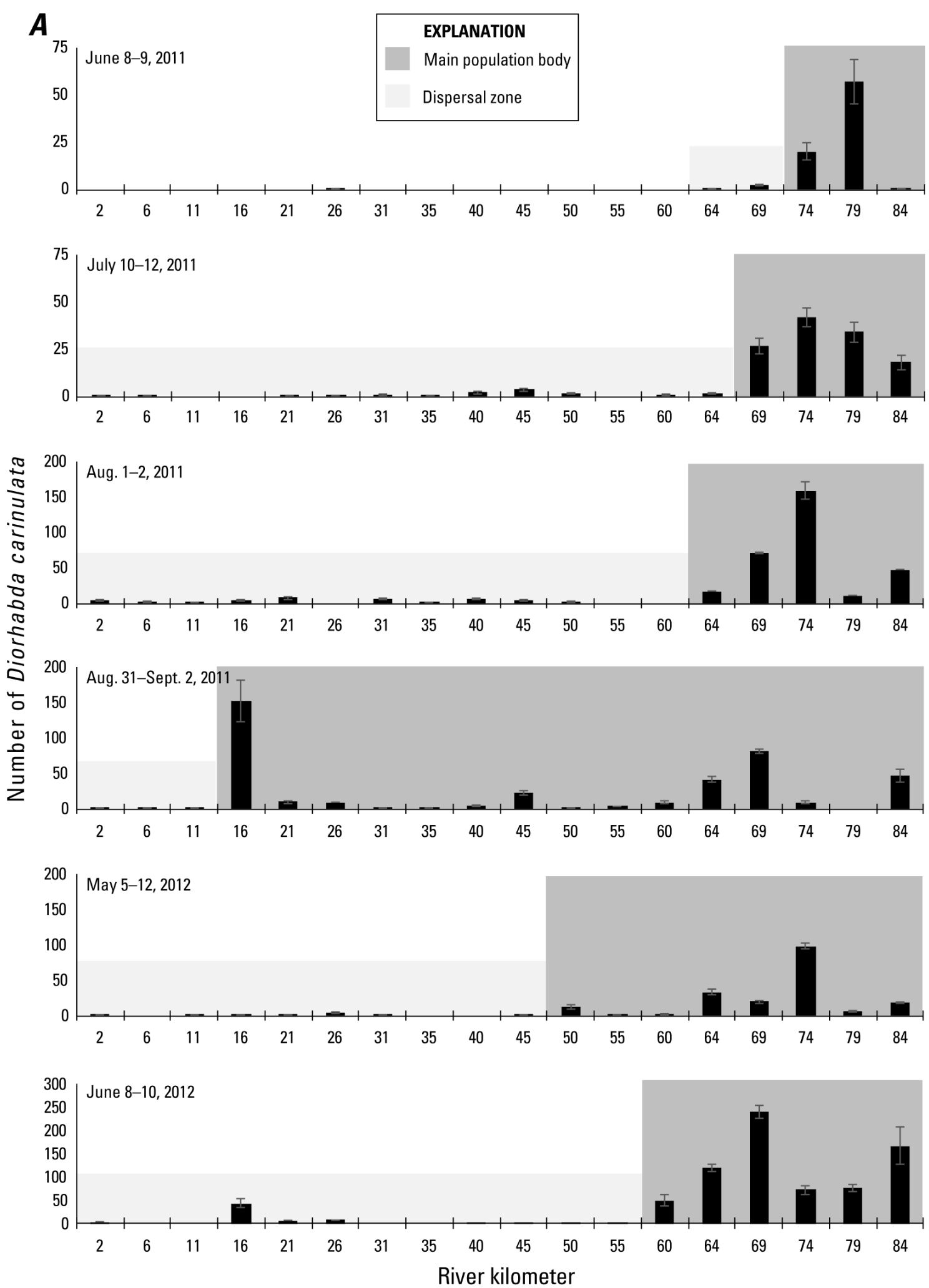

Figure 9. Monthly distributions of Diorhabda carinulata along the San Juan River near Farmington, New Mexico $(A)$, along the Colorado River in Marble Canyon $(B)$, and in the Grand Canyon, Arizona $(C)$, with main population bodies (dark gray areas) and dispersal zones (light gray areas) used for analysis highlighted. Error bars denote the standard error for each sampling point. 

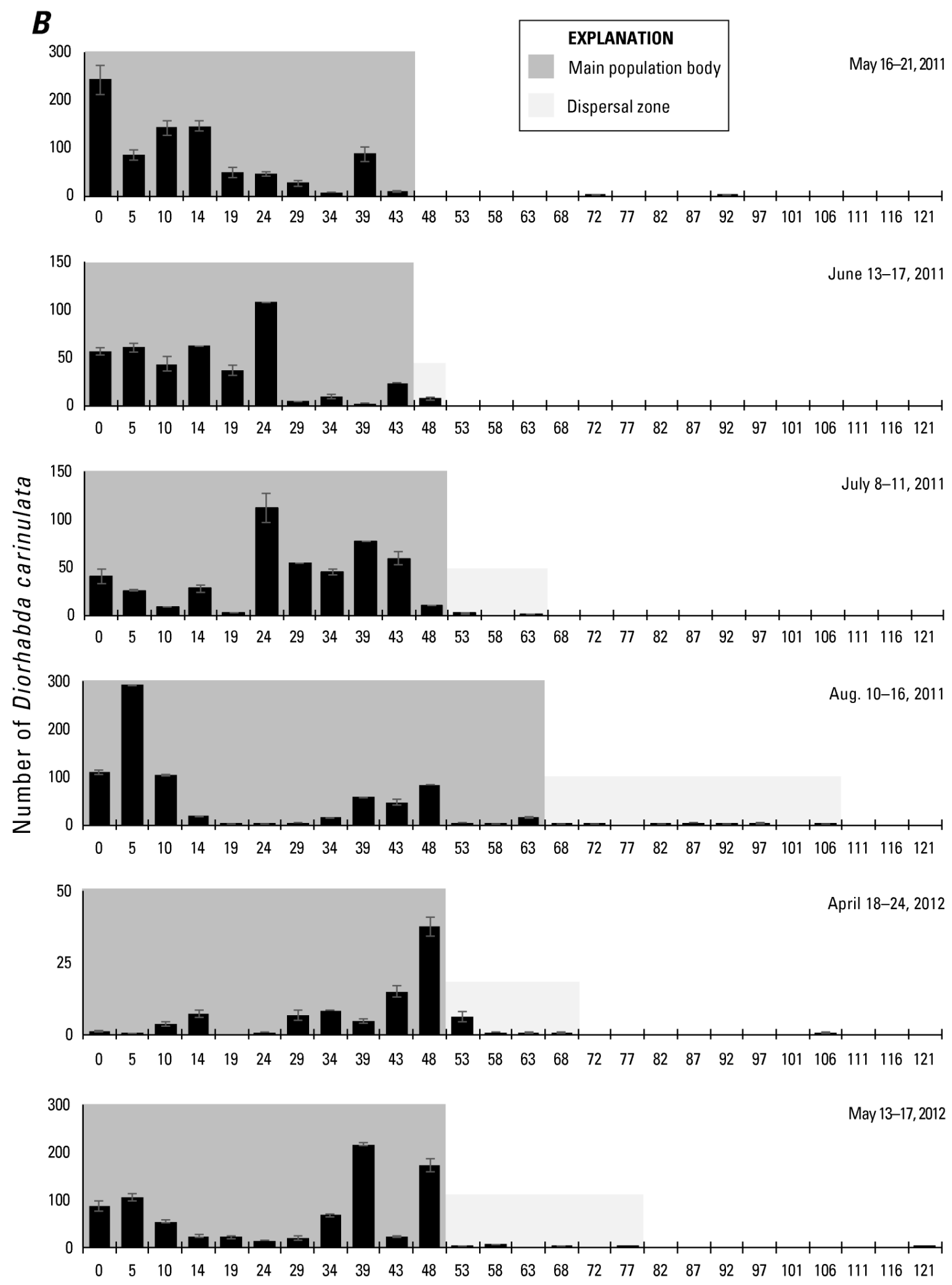

River kilometer

Figure 9.-Continued 

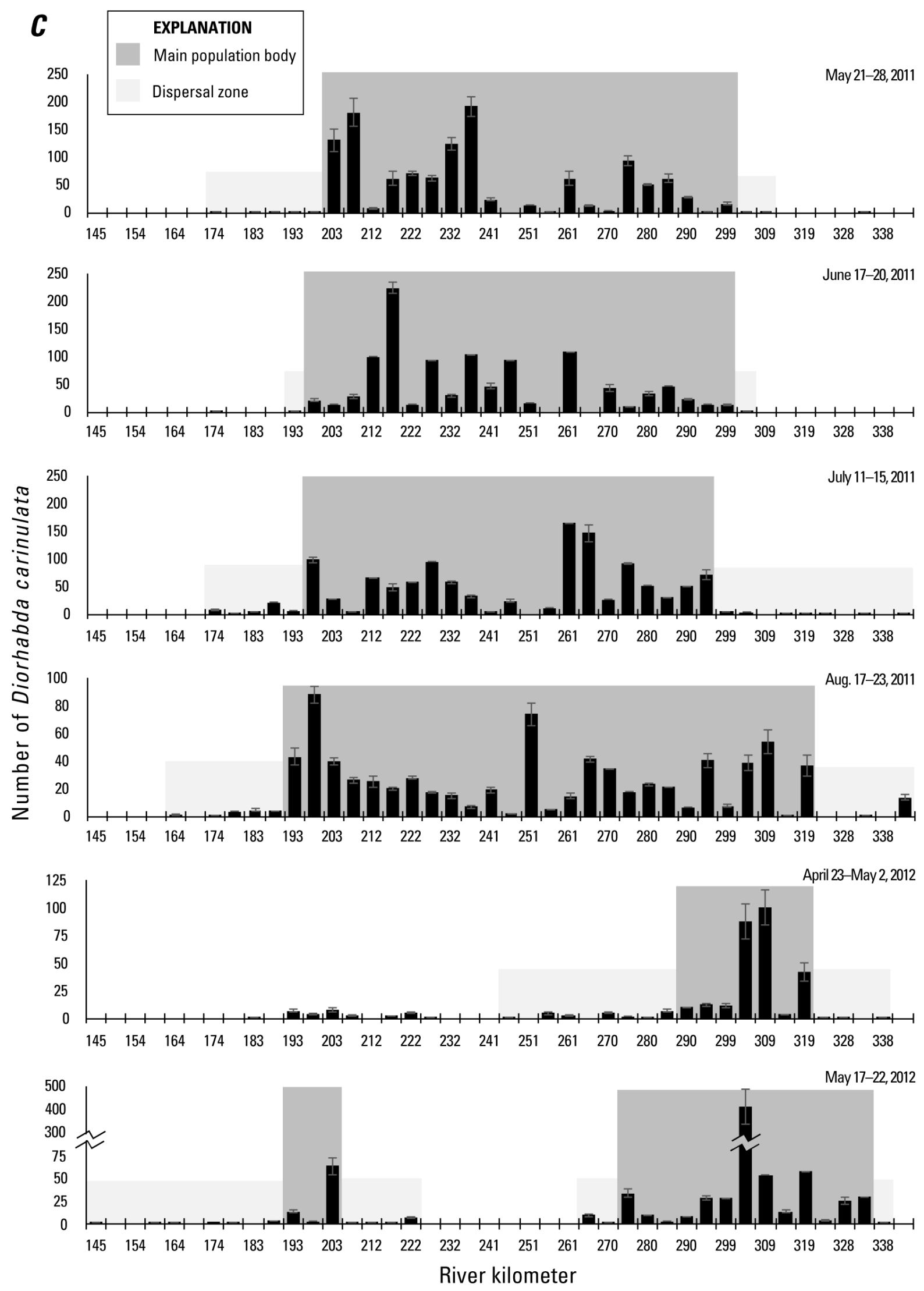

Figure 9.-Continued 
The dynamics of $D$. carinulata movement based on defoliation levels were most clearly observed at the Marble Canyon study site, where after completely defoliating the first $19 \mathrm{~km}$ of the study site, the larval population shifted downstream out of the $\geq 90$-percent defoliated area (fig. 12B). In response, tamarisk began to sprout new leaves in the areas where larvae were absent, prompting the beetles to repopulate the upper part of the site by August, once substantial refoliation of tamarisk had occurred (fig. 12B).

The sizes of the main population body and the dispersal zone increased at all study sites in 2011, with the upstream side of the Grand Canyon population exhibiting the smallest expansion (table 2). We attribute the beetle population increase at the San Juan study site (which went all the way to our study-site boundary) to immigration into the river corridor from the surrounding areas. During unrelated surveys and monitoring in 2011, we observed that our study site had become encompassed by a larger $D$. carinulata population surrounding the San Juan River corridor, with higher defoliation levels observed than that recorded at our study site. Both the Marble Canyon and Grand Canyon study sites were excluded from such influences, owing to their geologic and geographic isolation.
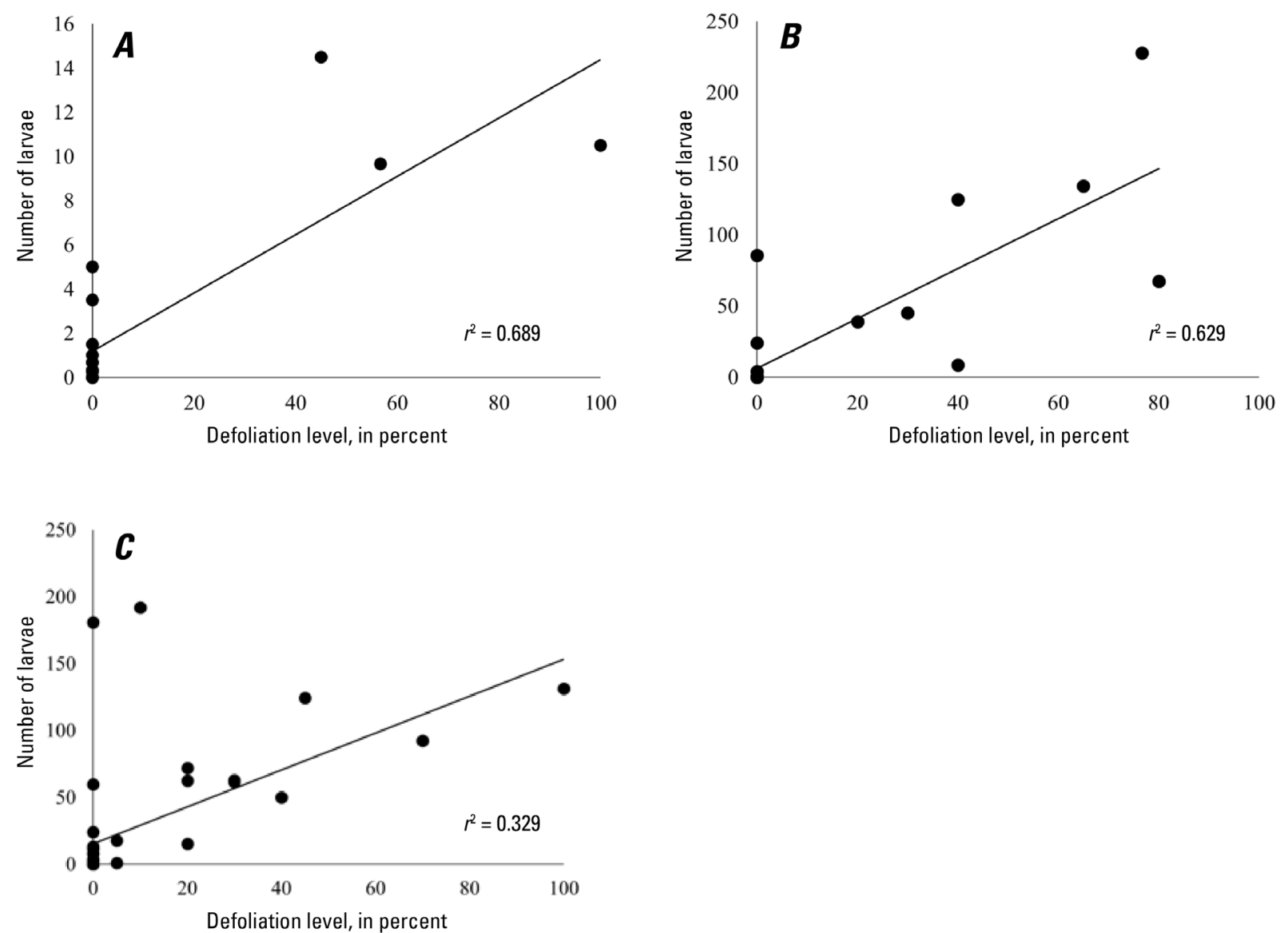

Figure 10. Number of first-summer-generation larvae versus defoliation level one month later at study sites in the Colorado River basin in 2011. A, San Juan study site, July-August $(r 2=0.689, p<0.05) . B$, Marble Canyon study site, May-June $\left(r^{2}=0.629, p<0.05\right)$. $C$, Grand Canyon study site, May-June $\left(r^{2}=0.329\right.$, $p<0.05) . r^{2}$ values describe the regression line fit, $p$ values describe the significance. 

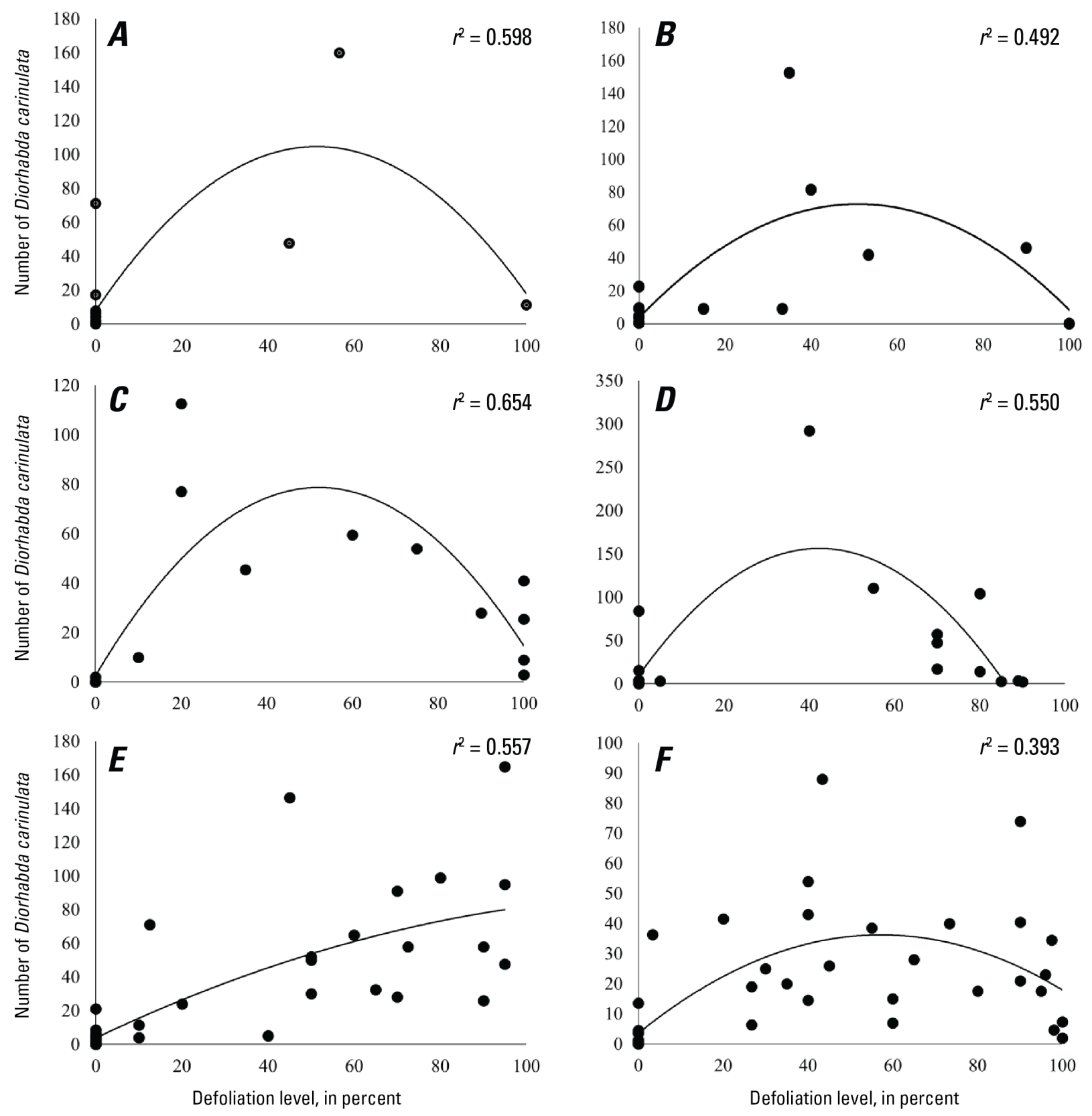

Figure 11. Number of Diorhabda carinulata versus defoliation level at study sites in the Colorado River basin midsummer 2011. A, San Juan study site, August $(r 2=0.598, p<0.05)$. $B$, San Juan study site, September $\left(r^{2}=0.492, p<0.05\right)$. C, Marble Canyon study site, July $\left(r^{2}=0.654, p<0.05\right)$. $D$, Marble Canyon study site, August $\left(r^{2}=0.550, p<0.05\right)$. $E$, Grand Canyon study site, July $\left(r^{2}=0.557, p<0.05\right)$. $F$, Grand Canyon study site, August $\left(r^{2}=0.393, p<0.05\right) . r^{2}$ values describe the regression line fit, $p$ values describe the significance.

No significant difference in the mean number of $D$. carinulata per sample from May to August 2011 was noted at either the Marble Canyon study site ( $F$ [Analysis of variance $\mathrm{F}$ value] $=1.32, d f$ [degrees of freedom] $=3,168, p=0.27)$ or the Grand Canyon site $(F=1.00, d f=$ $3,279, p=0.39$; fig. 13). Mean numbers of $D$. carinulata per sample in September were 
significantly lower at both study sites, suggesting that overwintering had begun to occur (Marble Canyon: $F=4.47, d f=4,230, p<0.05$; Grand Canyon: $F=7.03, d f=4,359, p<0.05$; figs. $9 B$, $C)$. At the San Juan study site, mean numbers of $D$. carinulata per sample differed significantly from June to September $2011(F=3.20, d f=3,187, p<0.05$; fig. 13$)$, as mean numbers greatly increased in August and September. From May to August, no significant difference was noted in the mean numbers of $D$. carinulata per sample at the Marble Canyon study site relative to the Grand Canyon study site (May: $F=0.09, d f=1$ [Marble Canyon study site] and 155 [Grand Canyon study site], $p=0.76$; June: $F=2.65, d f=1$ and $95, p=0.11$; July: $F=1.03, d f=1$ and $84, p=0.31$; August: $F=1.67, d f=1$ and $114, p=0.2$ ). Comparatively, at the San Juan study site, significantly lower mean numbers of $D$. carinulata per sample were noted in June and July in comparison with the other study sites, but not in August (June: $F=7.48, d f=2$ and 146, $p$ $<0.05$; July: $F=7.05, d f=2$ and 131, $p<0.05$; August: $F=1.04, d f=2$ and 157, $p=0.35$; fig. $13)$.

Comparing the mean number of $D$. carinulata per sample during the last month of activity (Marble Canyon and Grand Canyon: August surveys; San Juan: September surveys), and the first month of activity with abundant larvae, we found no significant difference at either the San Juan or Marble Canyon study sites (Marble Canyon, August $2011 \times$ May 2012: t statistic $(t)$ $=1.99, d f=76, p=0.67$; San Juan, September $2011 \times$ June 2012: $t=1.99, d f=73, p=0.15$; fig. 9), but a significant difference in the mean number of $D$. carinulata per sample in August 2011 relative to both April and May 2012 at the Grand Canyon study site (August $2011 \times$ April 2012: $t=1.97, d f=196, p<0.05$; August $2011 \times$ May 2012: $t=1.97, d f=146, p<0.05$; fig. 9). We noted a significant difference only when comparing the August mean to the May mean, when a large outlier was removed for May (outlier $=838$ D. carinulata, May mean without outlier $=8.99 \pm 2.46$ D. carinulata). Overwintering mortality was higher at the Grand Canyon study site relative to the other two study sites (table 3), disproportional to what we would expect in comparison with the other two study sites, although the difference was not quite significant $(F$ $=2.51, d f=2$ and $64, p=0.09$ ).

Table 2. Linear movement of Diorhabda carinulata population boundaries from May to August (Marble Canyon and Grand Canyon study sites) and from June to September 2011 (San Juan study site).

[All distances \pm 5.6 kilometers $(\mathrm{km})]$

\begin{tabular}{|c|c|c|}
\hline & \multicolumn{2}{|c|}{ Linear expansion of population zones in 2011 (km } \\
\hline & Main population body & Dispersal zone \\
\hline Marble Canyon (downstream) & 19.3 & 62.8 \\
\hline Grand Canyon (upstream) & 9.7 & 9.7 \\
\hline Grand Canyon (downstream) & 19.3 & 33.8 \\
\hline San Juan (upstream) ${ }^{1}$ & 57.9 & 62.8 \\
\hline Mean & 26.6 & 42.2 \\
\hline
\end{tabular}

${ }^{1}$ Results at the San Juan study site were confounded by immigration from a nearby population. Both the edge of the main population body and the dispersal zone continued beyond our study boundary.

Table 3. Collections of live and dead Diorhabda carinulata in leaf litter at the San Juan, Marble Canyon, and Grand Canyon study sites in the Colorado River basin in winter 2011-12.

\begin{tabular}{lcccc}
\hline \multicolumn{1}{c}{ Study site } & Live & $\begin{array}{c}\text { Percent of } \\
\text { total live }\end{array}$ & Dead & $\begin{array}{c}\text { Percent of } \\
\text { total dead }\end{array}$ \\
\hline San Juan & 49 & 98 & 1 & 2 \\
Marble Canyon & 33 & 94 & 2 & 6 \\
Grand Canyon & 59 & 77 & 18 & 23 \\
\hline
\end{tabular}



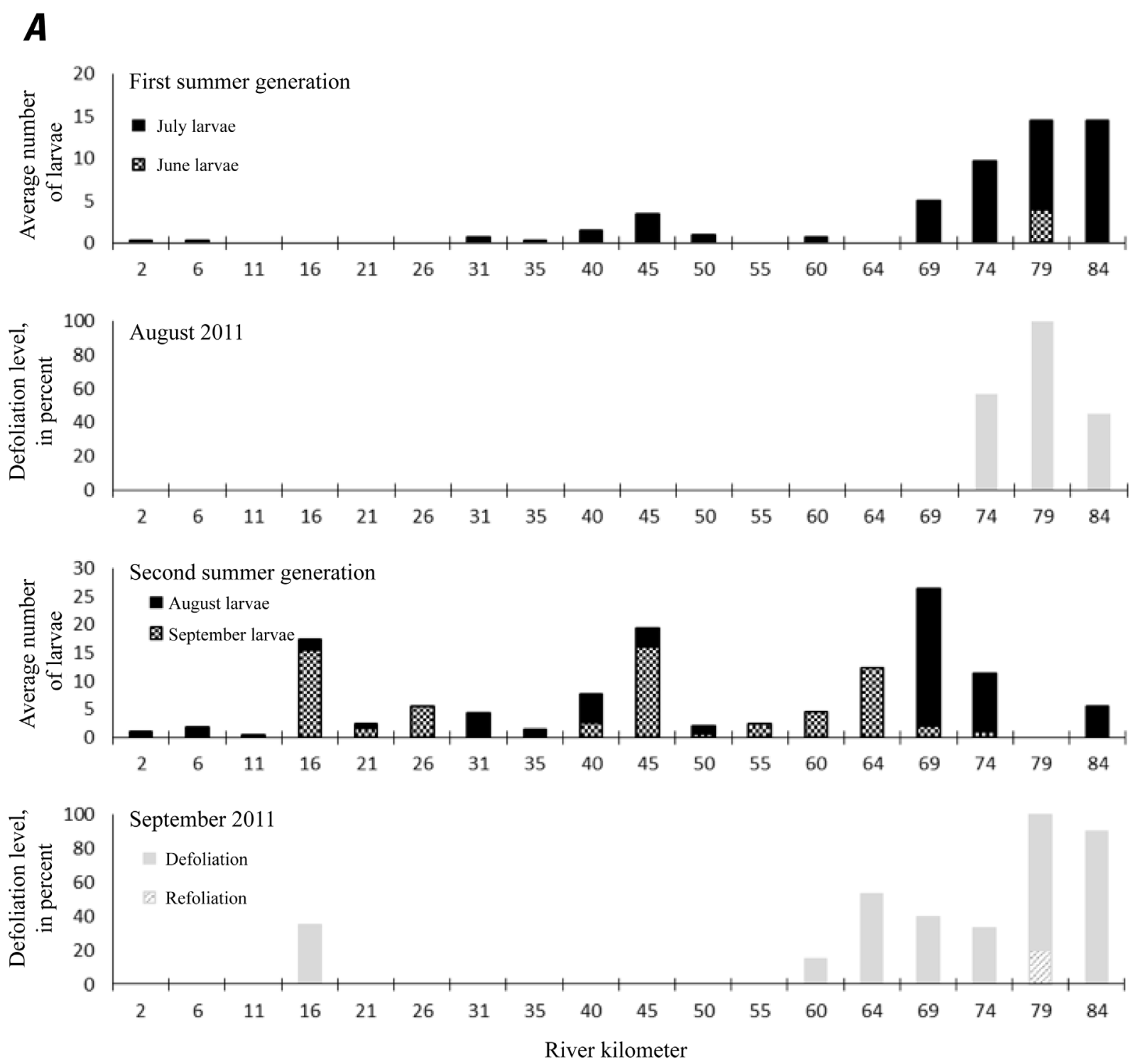

Figure 12. Spatial distributions of Diorhabda carinulata larvae and respective defoliation levels along the San Juan River near Farmington, New Mexico $(A)$, along the Colorado River in Marble Canyon $(B)$, and the Grand Canyon (C). Spatial distribution of defoliation levels at start of year correlates with that of average number of first-summer-generation larvae. In contrast, spatial distribution of average numbers of secondand third-summer-generation larvae correlates with that of higher defoliation levels, with larvae not recorded in areas $>90$-percent defoliated. 
B

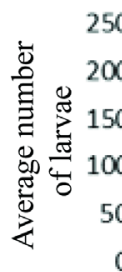

First summer generation

May and June 2011

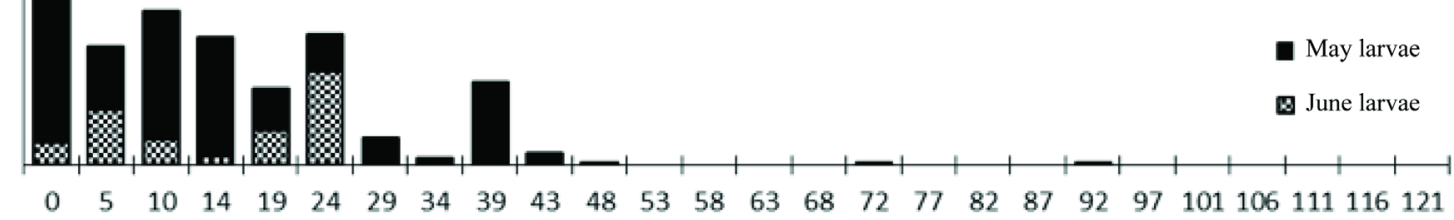

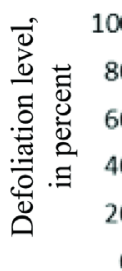

Defoliation

June 2011

Defoliation

Refoliation

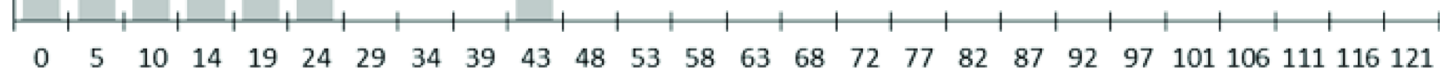

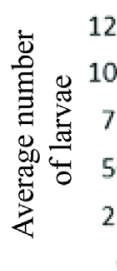

Second summer generation July 2011

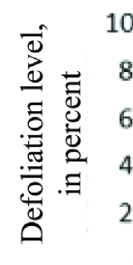

Defoliation July 2011

Defoliation

Refoliation
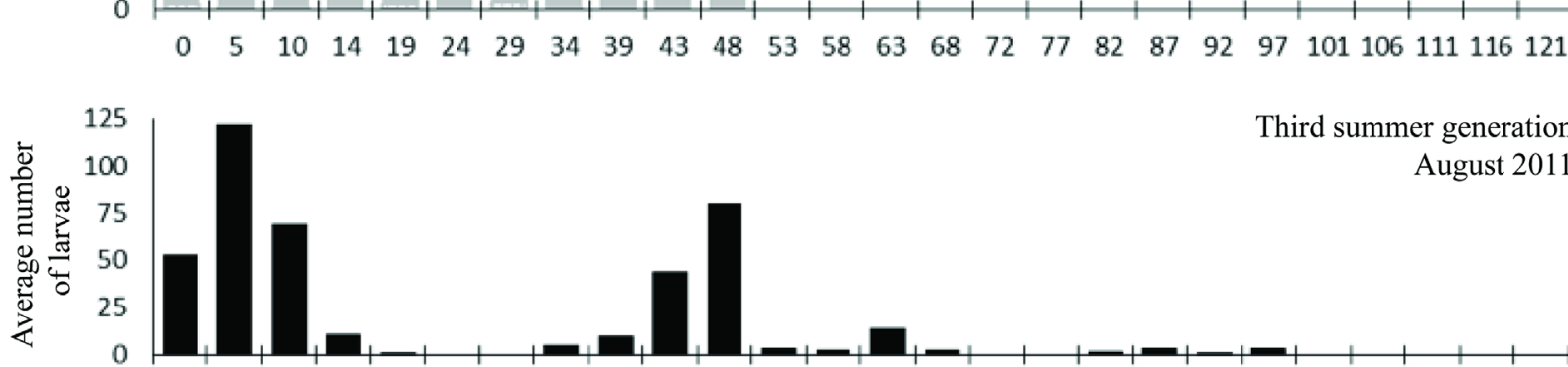

Third summer generation August 2011
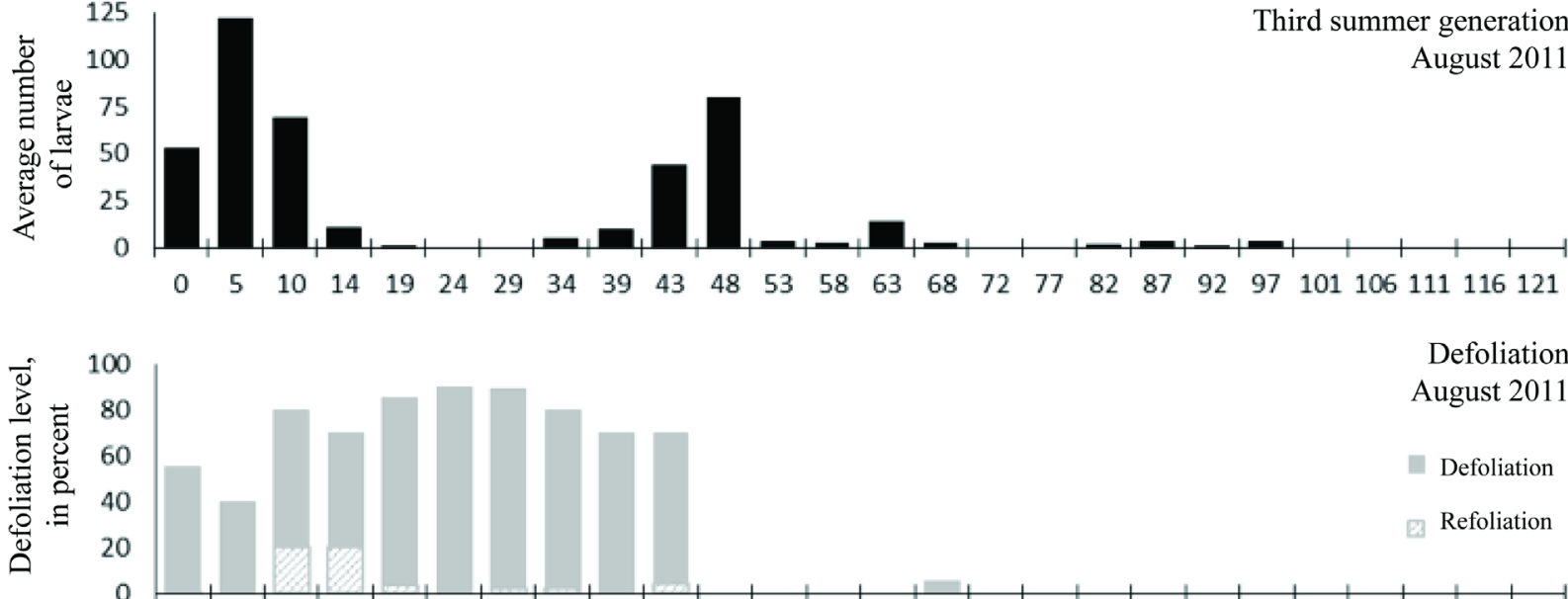

Defoliation August 2011

Defoliation

Refoliation

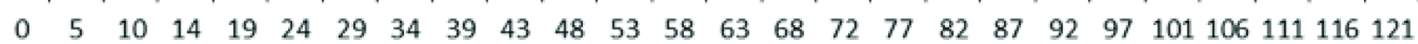

River kilometer

Figure 12.-Continued 

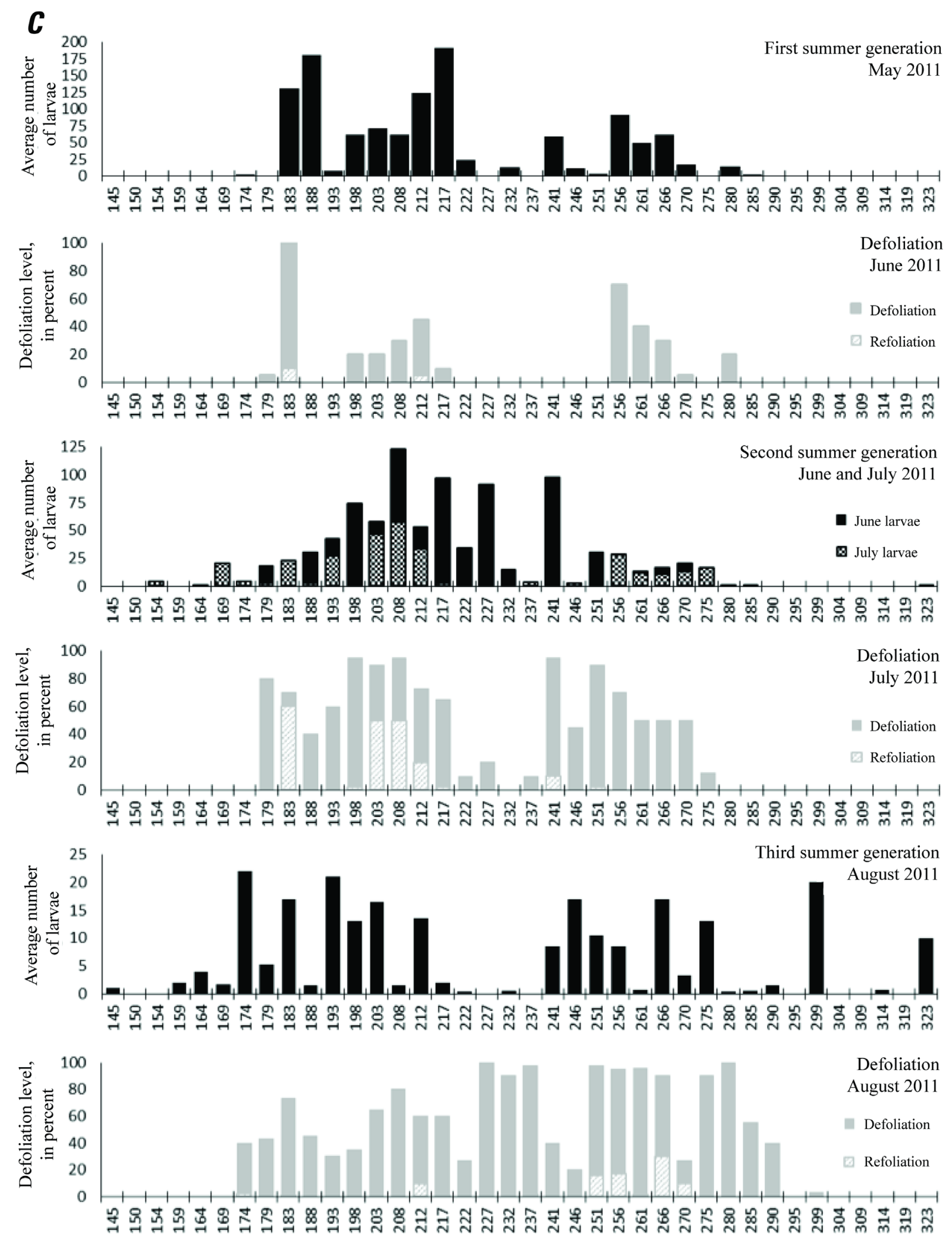

Figure 12.-Continued 


\section{Discussion}

\section{Influence of Abiotic Cues on Seasonal Timing}

We found 7-day-averaged daily temperatures of $16-24^{\circ} \mathrm{C}$ to be good predictors of the start of seasonal activity, directly correlated with how soon defoliation could occur in a given area. Herrera and others (2005) reported 100 percent mortality of all immature life stages, including eggs at $15{ }^{\circ} \mathrm{C}$ but full development at $20^{\circ} \mathrm{C}$. Together, our results suggest that ambient spring temperatures $>15^{\circ} \mathrm{C}$ control how early eggs of the first summer generation can be established and develop into larvae that will produce the first defoliation of the year. In areas where $D$. carinulata populations were high enough in our study, observable defoliation occurred within 1 month of the establishment of the first summer generation, spatially correlated with the relative abundance of larvae of that generation. At the Grand Canyon and Marble Canyon study sites, larger $D$. carinulata populations, coupled with earlier spring temperatures $>15^{\circ} \mathrm{C}$, resulted in defoliation occurring as early as late May and mid-June, respectively. In contrast, the San Juan study site had a lower $D$. carinulata population at the start of the season and temperatures did not allow for defoliation until mid-May, resulting in lower mean defoliation levels later than at the other two study sites.

Reproductive diapause occurred within the same two weeks of mid-August at all three study sites, ending dispersal and reproduction. Bean and others (2007a) initially reported the critical day length for $D$. carinulata populations across western North America to be $\sim 14$ hours 39 minutes, with $>50$ percent of the population entering reproductive diapause 13 days after the critical day length was reached. Bean and others (2012) refined these estimates, reporting that the critical day length for $D$. carinulata had changed across populations in North America 7 years after initial releases occurred. On the basis of our results, we estimate a critical day length for our study sites of somewhere between 13 hours 52 minutes and 14 hours 6 minutes, suggesting a critical day length for $D$. carinulata populations 33 to 47 minutes shorter than that of populations first introduced into North America in 2001.

Because the $D$. carinulata population at each of our study sites entered reproductive diapause within the same timeframe but differed in when they first became active, owing to spring temperatures, we noted a difference in how many new generations were produced in 2011. The "environmental container" of spring temperatures and fall day lengths in limiting voltinism rates has also been shown to occur in other leaf beetles (Dalin, 2011). Owing to the earlier arrival of warmer temperatures at the Marble Canyon and Grand Canyon study sites, an entire extra generation developed in comparison with the San Juan study site. As summer activity began as early as it did in 2012 compared to 2011, a fourth generation of D. carinulata might have occurred at the Grand Canyon study site in 2012. Differences in voltinism rates as a product of abiotic cues may significantly affect the growth rate of a population to defoliating levels. Although the hotter climates farther south from our study sites in the Mojave and Sonoran Deserts may allow earlier emergence of $D$. carinulata from overwintering, shortened day lengths due to the more southerly latitudes may also induce an earlier overwintering in the summer, thus still limiting this species to three or four generations. Comparatively, other species of Diorhabda, such as D. sublineata and D. elongata, may, in fact, be better suited for regions farther south of our study sites, because their biogeographic heritage is more similar to that of the lower deserts of North America (Tracy and Robbins, 2009). 


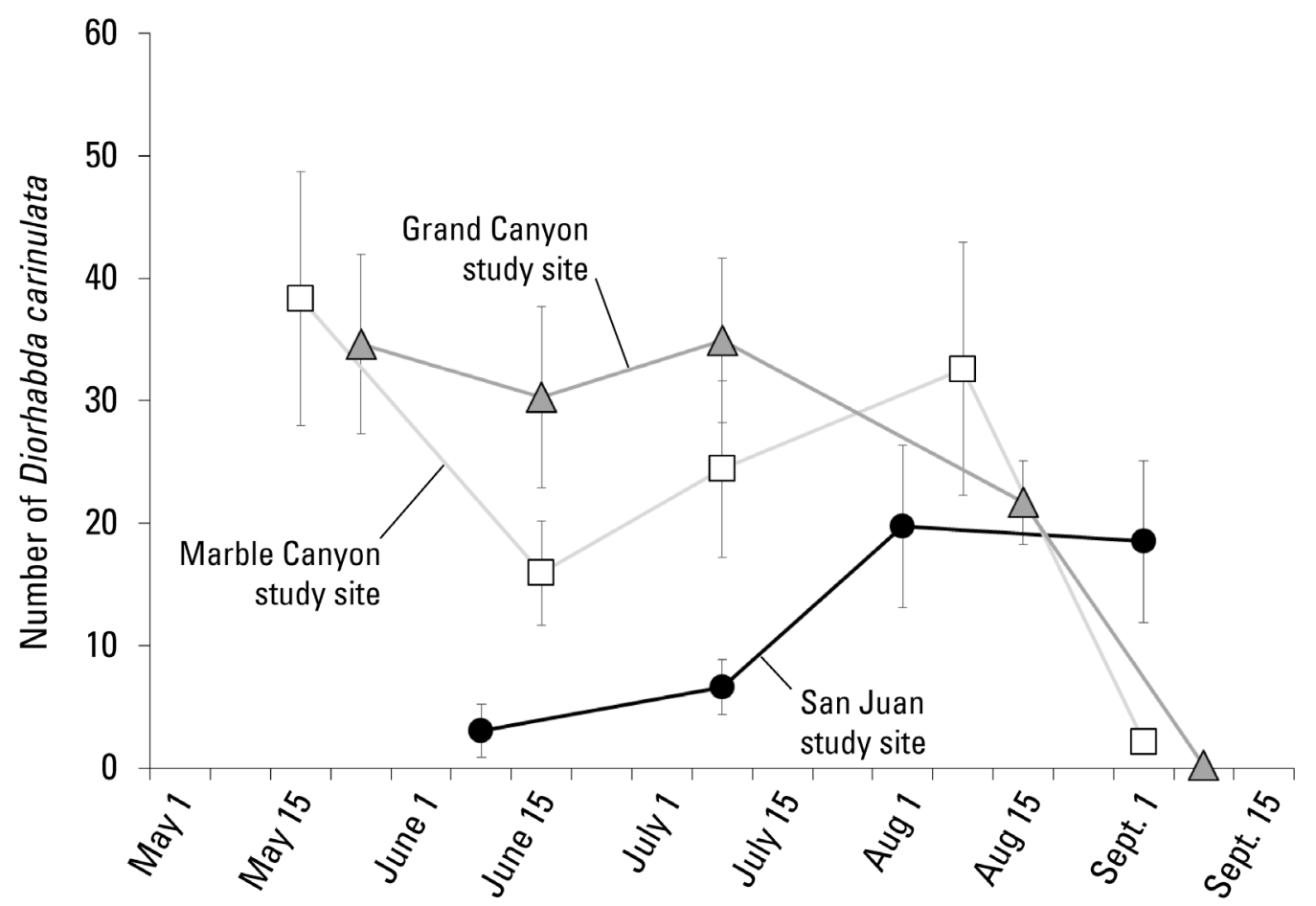

Date in 2011

Figure 13. Mean sample abundance of Diorhabda carinulata per monthly survey at the Marble Canyon (white squares), Grand Canyon (gray triangles), and San Juan (black circles) study sites in the Colorado River basin in 2011.

\section{Spatial Dynamics of $D$. carinulata and Defoliation}

Across our study area, we observed that $D$. carinulata populations declined once defoliation levels rose high enough to dissuade further establishment by $D$. carinulata. We recorded nearly a hundredfold difference between the mean numbers of $D$. carinulata in areas of 50-percent versus 100-percent defoliation ( $46 \pm 16.61[1 \sigma]$ and $0.42 \pm 0.16[1 \sigma]$, respectively). At the Marble Canyon study site, $>90$ percent defoliation was spread over the first $19 \mathrm{~km}$ of the river in July and was completely deserted by the second summer generation of larvae. Jamison and others (2015) reported the desertion of a large ( $>60 \mathrm{~km}$ long) defoliation zone along the Dolores River by $D$. carinulata, suggesting that beetles readily leave areas when food resources disappear. Our results complement Jamison and others' (2015) findings that areas will be abandoned when the defoliation level reaches $>90$ percent and may not be recolonized for $\geq 1$ year. Interannual variation in tamarisk defoliation levels have been reported in other studies as well (Hultine and others, 2010; Pattison and others, 2011; Nagler and others, 2012; Snyder and others, 2012), where $D$. carinulata populations decrease in the year(s) after a substantial season of defoliation. We suggest that this effect is likely due to emigration of beetles out of highly defoliated areas.

Snyder and others (2010) reported that leaf desiccation is a product of uncontrolled water loss through destroyed cells from beetle feeding and that feeding leads to inflated leaf loss more than would be expected. Although they detected no signs of chemical communication to initiate such a reaction in tamarisk, they proposed that exaggerated leaf loss may be an evolutionary reaction to herbivory, in which trees prematurely lose leaves to deprive beetles of an already- 
small food bank. Hudgeons and others (2007) reported that root carbohydrate reserves of tamarisk did not significantly differ between control trees and tamarisk defoliated for only 1 month, and that only extended periods of time (months to years) led to a significant reduction in defoliation. Tamarisk may have evolved to lose leaves to desiccation rapidly after intense feeding occurs so that herbivores may move on quicker, allowing trees the chance to return to normality sooner. We observed heavily defoliated areas to be both abandoned and rapidly refoliated within 1 month after herbivory ceased. Rapid refoliation of tamarisk after defoliation by D. carinulata has also been noted by other workers (Nagler and others, 2012; Snyder and others, 2012).

As $D$. carinulata emigrate from defoliated areas, dispersal appears to correlate in its rise with that of the increase in defoliation levels. The record for farthest dispersed D. carinulata was for one adult found $43 \mathrm{~km}$ from the main population body and $13 \mathrm{~km}$ from the nearest other beetle at the isolated Marble Canyon study site. Although the Marble Canyon and San Juan study sites had a similar level of expansion of both the main population body and the dispersal zones, we believe that our results were confounded at the San Juan study site by immigration into the site from a greater regional population. D. carinulata population at the San Juan study site significantly increased as soon as the first summer generation of larvae pupated altogether into winged adults by the start of August 2011. This observation would support our notion that the $D$. carinulata population increase at this study site in August and September was a result of immigration as winged adults of the first summer generation could finally disperse out of other defoliated areas into the river corridor where we sampled.

Owing to the open topography of the San Juan study site, D. carinulata population movement there would have been less inhibited than within the deeply entrenched canyons of the Marble Canyon and Grand Canyon study sites. On the basis of surveys outside the dates of this study, we observed that both Marble Canyon and Grand Canyon study sites would have lacked much influence from surrounding $D$. carinulata populations, owing to the sparseness of tamarisk across the areas surrounding those canyons. As a result, these two study sites were more topographically and geographically isolated from other $D$. carinulata populations than the San Juan study site. We believe that the combination of topography, geographic isolation, average temperature, and day length all affected the population dynamics that we observed during our study. The San Juan study site, which had the smallest $D$. carinulata population, also had the largest increase in population size, owing to the geography and topography of the study site. Because the San Juan study site was the coldest, with the shortest active season, only two new summer generations occurred there. In contrast, the Marble Canyon study site produced three new summer generations, had the most cohesive population movement of all the study sites, and exhibited the same patterns of other large colonizing $D$. carinulata populations reported elsewhere (Jamison and others, 2015). Although the Marble Canyon study site had a lower rate of population expansion than the San Juan study site, the mean abundance of $D$. carinulata was consistently higher there than at the San Juan study site. Comparatively, the Grand Canyon study site was the warmest, resulting in almost four new summer generations. Population movement there differed from that at the Marble Canyon study site in that it was less cohesive and more scattered. Additionally, we observed significant mortality in the winter of 2011-12 at the Grand Canyon study site, resulting in a significantly reduced $D$. carinulata population in the following spring.

We attribute the decline and lack of expansion in the $D$. carinulata population at the Grand Canyon study site to the geology and habitat suitability of the study site, in which riparian 
vegetation and tamarisk are generally sparse in various parts of the canyon. We noted an observable boundary in the middle of the Grand Canyon at $\mathrm{km} 246$ that appeared to divide the $D$. carinulata population in two. This boundary occurs along a geologic stretch of canyon called the Muav Gorge (km 227-280), a very narrow and deep-walled part of the canyon in which vegetation in riparian zones is less abundant. We believe that the geologic setting of the Muav Gorge and that of the canyon at the upstream side of the Grand Canyon study site significantly affected the increase and expansion of the D. carinulata population upstream of $\mathrm{km} 285$ in the Grand Canyon. The relative scarcity of tamarisk may explain why we observed a disproportionate number of dead overwintering beetles relative to what we would have expected. Out of the 18 dead D. carinulata found in winter in the Grand Canyon study site, 13 were within the Muav Gorge, and 4 others near the upstream boundary of the study site. Bean and others (2007b) described how D. carinulata procure fat bodies upon induction into diapause, for fueling metabolic activity throughout overwintering. It is reasonable to suggest that in areas of high defoliation and sparse tamarisk, finding sufficient foliage to feed and sequester fat bodies before overwintering may be a challenge. The mean abundances of $D$. carinulata at the Grand Canyon study site in April and May 2012 were significantly lower than in August 2011, suggesting two important points: (1) resource scarcity (whether due to defoliation or scarcity of tamarisk) may influence the overwintering mortality rates of $D$. carinulata; and (2) winter mortality will significantly lower the $D$. carinulata population, decreasing the defoliation potential of the firstsummer-generation larvae in the following spring.

We noted a significant correlation between the spatial distribution of each population in fall 2011 and spring 2012. Because we would not expect the distribution of a population to move over the winter (barring mortality), the spatial correlation between the population in the fall and spring is useful for forecasting the location of high-abundance first-summer-generation larvae in the next year. Because of this correlation, as well as that between the abundance of first-summergeneration larvae and the intensity level of the first defoliation of the year, the occurrence and location of initial tamarisk defoliation may be predictable 6 months or more before it occurs.

Although defoliation from first-summer-generation larvae is related to the distribution of the $D$. carinulata population in the proceeding fall, we observed defoliation in the season from second- and third-generation larvae to occur in one of two ways: (1) first-summer-generation larval abundances, and thus initial defoliation, were low enough that second-generation larvae were established within the same area, only intensifying defoliation levels; or (2) first-summergeneration larval abundances were high enough to cause substantial defoliation, and subsequent pupation into the adult stage would cause emigration out into areas with sufficient green foliage to establish the second summer generation, which would then begin to defoliate new areas, or areas with low larval abundances as in the first way. Any third-generation larvae would be established and cause defoliation in the same way, on the basis of abundances and movement of the second summer generation. Thus, the timing of defoliation by the second and later summer generations of larvae will depend on the rate and timing of pupation of each generation, and this defoliation will occur only in areas where defoliation from the previous generation was not too high.

\section{Conclusion}

The management of invasive tamarisk and the conservation of riparian forests in North America is a dynamic situation involving many challenges. Tamarisk, interestingly now in need of protection and conservation in parts of its native Central Asia (Zhang and Zhang, 2012), is 
simultaneously spreading in Australia and Argentina (Griffin and others, 1989; Natale and others, 2013). The introduction of Diorhabda spp. to North America may be a useful occurrence in which we can study its effectiveness as a biologic control mechanism, while also observing its dynamic interactions with tamarisk. The ability to predict the timing of tamarisk defoliation by D. carinulata is useful if we are concerned about the impacts of defoliation on other organisms. Our findings suggest that the synthesis of (1) abiotic cues, (2) spatial distribution of $D$. carinulata, and (3) movement of $D$. carinulata as affected by resource destruction (that is, defoliation) during summer, may permit prediction of when and where defoliation will occur across a given landscape. This information may be useful for planning restoration with regard to other species conservation when considering the potential use and impacts of tamarisk defoliation by $D$. carinulata.

With regard to the conservation of breeding birds, for example, the timing of initial defoliation by the first-summer-generation larvae as a product of springtime temperature rise is of unique concern. Paxton and others (2011) presented a case concerning tamarisk defoliation as an "ecological trap," whereby breeding birds build nests in tamarisk before the occurrence of defoliation, only to have defoliation occur once they have begun incubating eggs or feeding nestlings, leading to a significant increase in nest failure. To illustrate their concerns, Paxton and others (2011) compared initial tamarisk-defoliation dates at a site near Dolores, Colo. with the timing of Southwestern Willow Flycatcher breeding events in Roosevelt, Ariz. (fig. 1). On the basis of this comparison, they predicted that defoliation would occur after Southwestern Willow Flycatchers began nesting but before fledging their young, so that birds would be led into an ecological trap related to the timing of defoliation and bird phenology. Although the example used by Paxton and others (2011) was purely hypothetical to explain a point of concern, on the basis of our results we would expect a different result if this scenario actually occurred in Roosevelt, Ariz. On the basis of our observed correlation between $D$. carinulata activity and springtime temperature rise, in this scenario we would expect defoliation from first-summergeneration larvae to initially occur in Roosevelt, Ariz., by late April or early May (similar to what occurred at the Grand Canyon study site), during the period in which most Southwestern Willow Flycatchers would have migrated into the area and $\geq 6$ weeks before eggs would be laid (Sogge and others, 1997; Ellis and others, 2009). Thus, we would expect an entirely different outcome, in which defoliation would occur before nesting sites were chosen, giving Southwestern Willow Flycatchers the chance to avoid tamarisk for nesting.

Comparatively, if this hypothetical scenario were to occur instead in Dolores, Colo., on the basis of our results, two different outcomes could ensue. (1) If $D$. carinulata abundances were too low to noticeably defoliate an area with first-summer-generation larvae, and if defoliating levels were not achieved until the second summer generation, then defoliation would not be expected to occur until early August to mid-August, at which point most Southwestern Willow Flycatchers would have fledglings or be migrating. Conversely (2), if this generation overwintered in high abundances, then we would expect high defoliation levels in the next spring at the height of incubation, just as Paxton and others (2011) suggested. Furthermore, if defoliation levels then were high enough, we would expect the D. carinulata population to abandon the area, dispersing in the adult stage to establish the second summer generation in a new area. Because only two new summer generations would be expected in Dolores, Colo., the second summer generation would become the overwintering generation, and as a result the area of initially high defoliation level would be devoid of $D$. carinulata for a whole year until adults of the first summer generation in the following season could finally migrate back around mid- 
July. Thus, because our results on defoliation timing are a product of abiotic cues, spatial abundances and dispersal of beetles from overconsumed areas have specific value to the concerns presented by Paxton and others (2011).

Given the continued movement of $D$. carinulata and other more southern adapted Diorhabda species (D. sublineata and D. elongata) into Southwestern Willow Flycatcher critical habitat (Bloodworth and others, 2016), further research is warranted on the adaptability of $D$. carinulata to lower latitudes and on the abiotic restraints governing the timing of activity in $D$. sublineata and D. elongata. Because Diorhabda spp. will likely colonize tamarisk across the range of the Southwestern Willow Flycatcher, understanding the dynamics of tamarisk defoliation and the response of Southwestern Willow Flycatchers to tamarisk defoliation will be useful for protecting the bird during its reproductive season. Our results provide a rationale by which to understand and predict the variation in the timing of defoliation across a given landscape and may be useful for the conservation of riparian habitats.

\section{Management Implications}

- The duration of annual activity of $D$. carinulata will be dictated by rising temperatures in the spring and shortening day lengths in the fall. These abiotic cues will dictate the number of new generations, the timing of initial defoliation, and when D. carinulata will disappear and defoliation will cease.

- The abundance of D. carinulata in the fall, just before overwintering, will be useful in predicting the location of initial defoliation in the next spring. The timing and location of the first defoliation events of the year can be predicted $\geq 6$ months before.

- If defoliation levels reach $>90$ percent, $D$. carinulata will emigrate until sufficient green foliage returns. $D$. carinulata may abandon an area for as long as a year.

- The density of tamarisk in an area may limit the size of a $D$. carinulata population, and areas with sparse tamarisk may not allow sustainable levels of $D$. carinulata population.

- Winter mortality may have a large impact on how quickly a $D$. carinulata population can increase defoliation level in the following spring.

\section{Acknowledgments}

We thank C. Holmes, N. Ament, A. Chandler, S. Eginoire, D. Erickson, J. Lanci, L. Tate, C. Taylor, B. Cooper, and C. Kropp for assisting with data collection. M. Johnson, L. Mackarick, and M. McMaster were crucial in coordinating aspects of this project. T. Higgs and W. Robinson helped provide original tamarisk-beetle release-site data. T. Dudley, B. Ochoa, and two anonymous reviewers contributed helpful reviews of the manuscript. We are especially grateful for the support of M. Johnson, D. Bean, R. Dennis, and the Jamison family.

\section{References Cited}

Bean, D.W., Dalin, P., and Dudley, T.L., 2012, Evolution of critical day length for diapause induction enables range expansion of Diorhabda carinulata, a biological control agent against tamarisk (Tamarix spp.): Evolutionary Applications, v. 5, p. 511-523.

Bean, D.W., Dudley, T.L. and Keller, J.C., 2007a, Seasonal timing of diapause induction limits the effective range of Diorhabda elongata deserticola (Coleoptera: Chrysomelidae) as a biological control agent for tamarisk (Tamarix spp.): Environmental Entomology, v. 36, p. 1525 . 
Bean, D.W., Wang, T., Bartelt, R.J., and Zilkowski, B.W., 2007b, Diapause in the leaf beetle Diorhabda elongata (Coleoptera: Chrysomelidae), a biological control agent for tamarisk (Tamarix spp.): Environmental Entomology, v. 36, p. 531-540.

Bloodworth, B.R., Shafroth, P.B., Sher, A.A., Manners, R.B., Bean, D.W., Johnson, M.J., and Hinojosa-Huerta, O., 2016, Tamarisk beetle (Diorhabda spp.) in the Colorado River basin; synthesis of an expert panel forum: Grand Junction, Colorado Mesa University, Ruth Powell Hutchins Water Center Scientific and Technical Report 1, 19 p.

Brown, B.T. and Trosset, M.W., 1989, Nesting-habitat relationships of riparian birds along the Colorado River in Grand Canyon, Arizona: The Southwestern Naturalist, v. 34, no. 2, p. 260 270.

Dalin, P., 2011, Diapause induction and termination in a commonly univoltine leaf beetle (Phratora vulgatissima): Insect Science, v. 18, p. 443-450.

Dalin, P., Bean, D.W., Dudley, T.L., Carney, V.A., Eberts, D., Gardner, K.T., Hebertson, E., Jones, E.N., Kazmer, D.J., Michels, Jr., G.J., O'meara, S.A., and Thompson, D.C., 2010, Seasonal adaptations to day length in ecotypes of Diorhabda spp. (Coleoptera: Chrysomelidae) inform selection of agents against saltcedars (Tamarix spp.): Environmental Entomology, v. 39 , no. 5, p. 1666-1675.

Di Tomaso, J.M., 1998, Impact, biology, and ecology of saltcedar (Tamarix spp.) in the Southwestern United States: Weed Technology, v. 12, p. 326-336.

Dudley, T.L., and Bean, D.W., 2012, Tamarisk biocontrol, endangered species risk and resolution of conflict through riparian restoration: BioControl, v. 57, p. 331-347.

Dudley, T.L., Bean, D.W., Pattison, R.R., and Caires, A., 2012, Selectivity of a biological control agent, Diorhabda carinulata Desbrochers, 1870 (Coleoptera: Chrysomelidae) for host species within the genus Tamarix Linneaus, 1753: Pan-Pacific Entomologist, v. 88, no. 3, p. 319-341.

Dunwiddie, P.W., Haan, N.L., Linders, M., Bakker, J.D., Fimbel, C., and Thomas, T.B., 2016, Intertwined fates-Opportunities and challenges in the linked recovery of two rare species: Natural Areas Journal, v. 36, no. 2, p. 207-215.

Ellis, L.A., Stump, S.D., and Weddle, D.M., 2009, Southwestern willow flycatcher population and habitat response to reservoir inundation: Journal of Wildlife Management, v. 73, no. 6, p. 946-954.

Friedman, J.M., Auble, G.T., Shafroth, P.B., Scott, M.L., Merigliano, M.F., Freehling, M.D., and Griffin, E.R., 2005, Dominance of non-native riparian trees in western USA: Biological Invasions, v. 7, p. 747-751.

Griffin, G.F., Smith, D.M.S., Morton, S.R., Allan, G.E., Masters, K.A., Preece, N., 1989, Status and implications of the invasion of tamarisk (Tamarix aphylla) on the Finke River, Northern Territory, Australia: Journal of Environmental Management, v. 29, p. 297-315.

Herrera, A.M., Dahlsten, D.D., Tomic-Carruthers, N., and Carruthers, R.I., 2005, Estimating temperature-dependent developmental rates of Diorhabda elongata (Coleoptera:

Chrysomelidae), a biological control agent of saltcedar (Tamarix spp.): Environmental Entomology, v. 34, p. 775-784.

Hudgeons, J.L., Knutson, A.E., Heinz, K.M., DeLoach, C.J., Dudley, T.L., Pattison, R.R., and Kiniry, J.R., 2007, Defoliation by introduced Diorhabda elongata leaf beetles (Coleoptera: Chrysomelidae) reduces carbohydrate reserves and regrowth of Tamarix (Tamaricaceae):

Biological Control, v. 43, p. 213-221. 
Hultine, K.R., Dudley, T.L., Koepke, D.F., Bean, D.W., Glenn, E.P., and Lamber, A.M., 2015, Patterns of herbivory-induced mortality of a dominant non-native tree/shrub (Tamarix spp.) in a southwestern U.S. watershed: Biological Invasions, v. 17, p. 1729-1742.

Hultine, K.R., Nagler, P.L., Morino, K., Bush, S.E., Burtch, K.G., Dennison, P.E., Glenn, E.P., and Ehleringer, J.R., 2010, Sap flux-scaled transpiration by Tamarisk (Tamarix spp.) before, during, and after episodic defoliation by the saltcedar leaf beetle (Diorhabda carinulata):

Agriculture and Forest Meteorology, v. 150, p. 1467-1475.

Jamison, L.R., van Riper, C., III, and Bean, D.W., 2015, The influence of Tamarix ramosissima defoliation on population movements of the northern tamarisk beetle (Diorhabda carinulata) within the Colorado Plateau, in Huenneke, L.F., van Riper, C., III, and Hays-Gilpin, K.A., The Colorado Plateau VI-Science and management at the landscape scale: Tucson, University of Arizona Press, p. 281-291.

Lewis, P.A., DeLoach, C.J., Knutson, A.E., Tracy, J.L., and Robbins, T.O., 2003, Biology of Diorhabda elongata deserticola (Coleoptera: Chrysomelidae), an Asian leaf beetle for biological control of saltcedars (Tamarix spp.) in the United States: Biological Control, v. 27, p. 101-116.

Meng, R., Dennison, P.E., Jamison, L.R., van Riper, C., III, Nagler, P., Hultine, K.R., Bean, D.W., and Dudley, T., 2012, Detection of tamarisk defoliation by the northern tamarisk beetle based on Multitemporal Landsat 5 Thematic Mapper imagery: GIScience \& Remote Sensing, v. 49, p. 510-537.

Milbrath, L.R., Deloach, C.J., and Tracy, J.L., 2007, Overwintering survival, phenology, voltinism, and reproduction among different populations of the leaf beetle Diorhabda elongata (Coleoptera: Chrysomelidae): Environmental Entomology, v. 36, p. 1356-1364.

Nagler, P.L., Brown, T., Hultine, K.R., van Riper, C., III, Bean, D.W., Dennison, P.E., Scott Murray, R., and Glenn, E.P., 2012, Regional scale impacts of Tamarix leaf beetles (Diorhabda carinulata) on the water availability of western U.S. rivers as determined by multi-scale remote sensing methods: Remote Sensing of Environment, v. 118, p. 227-240.

Natale, E., Zalba, S.M., and Reinoso, H., 2013, Presence-absence versus invasive status data for modelling potential distribution of invasive plants-Saltcedar in Argentina: Ecoscience, v. 20, p. 161-171.

Pattison, R.R., D’Antonio, C.M., Dudley, T.L., Allander, K.K., Rice, B., 2011, Early impacts of biological control on canopy cover and water use of the invasive saltcedar tree (Tamarix spp.) in western Nevada, USA: Oecologia, v. 165, p. 605-616.

Paxton, E.H., Theimer, T.C., Sogge, M.K., 2011, Tamarisk biocontrol using tamarisk beetlesPotential consequences for riparian birds in the southwestern United States: Condor, v. 113, p. 255-265.

Peterson, D., Pellegrini, A.R., Mcleod, M.A., and Theimer, T.C., 2015, Standing water is positively correlated with invertebrate biomass, nestling feeding rate and productivity in Southwestern willow flycatchers (Empidonax traillii extimus), in Huenneke, L.F., van Riper, C., III, and Hays-Gilpin, K.A., The Colorado Plateau VI-Science and management at the landscape scale: Tucson, University of Arizona Press, p. 262-270.

Sanchez-Peña Celso Morales-Reyes, S.R., Herrera-Aguayo, F., Torres-Acosta, I., CamachoPonce, D., Gonzalez-Gallegos, E., Ritzi Joe Sirotnak, C., and Briggs, M., 2016, Distribution of the subtropical tamarisk beetle, Diorhabda sublineata (Lucas, 1849) (Coleoptera:

Chrysomelidae), in Mexico: Pan-Pacific Entomologist, v. 92, no. 1, p. 56-62. 
Shafroth, P.B., and Briggs, M.K., 2008, Restoration ecology and invasive riparian plants; an introduction to the special section on Tamarix spp. in western North America: Restoration Ecology, v. 16, no. 1, p. 94-96.

Shafroth, P.B., Cleverly, J.R., Dudley, T.L., Taylor, J.P., van Riper, C., III, Weeks, E.P., and Stuart, J.N., 2005, Control of Tamarix in the Western United States-Implications for water salvage, wildlife use, and riparian restoration: Environmental Management, v. 35, p. 231-246.

Snyder, K.A., Scott, R.L., and McGwire, K., 2012, Multiple year effects of a biological control agent (Diorhabda carinulata) on Tamarix (saltcedar) ecosystem exchanges of carbon dioxide and water: Agricultural and Forest Meteorology, v. 164, p. 161-169.

Snyder, K.A., Uselman, S.M., Jones, T.J., and Duke, S., 2010, Ecophysiological responses of salt cedar (Tamarix spp. L.) to the northern tamarisk beetle (Diorhabda carinulata Desbrochers) in a controlled environment: Biological Invasions, v. 12, p. 3795-3808.

Sogge, M.K., Marshall, R.M., Sferra, S.J., and Tibbitts, T.J., 1997, A Southwestern willow flycatcher natural history summary and survey protocol: Flagstaff, Ariz., National Park Service, Colorado Plateau Research Station Report NRTR-97/12, 36 p.

Sogge, M.K., Sferra, S.J., and Paxton, E.H., 2008, Tamarix as habitat for birds-Implications for riparian restoration in the Southwestern United States: Restoration Ecology, v. 16, p. 146-154.

Tracy, J.L., and Robbins, T.O., 2009, Taxonomic revision and biogeography of the Tamarix feeding Diorhabda elongata (Brullé, 1832) species group (Coleoptera: Chrysomelidae: Galerucinae: Galerucini) and analysis of their potential in biological control of Tamarisk: Zootaxa, v. 2101, p. 1-152.

Turner, M.G., O'Neill, R.V., Gardner, R.H., and Milne, B.T., 1989, Effects of changing spatial scale on the analysis of landscape pattern: Landscape Ecology, v. 3, p. 153-162.

van Riper, C., III, Paxton, K.L., O’Brien, C., Shafroth, P.B., and McGrath, L.J., 2008, Rethinking avian response to Tamarix on the lower Colorado River-A threshold hypothesis: Restoration Ecology, v. 16, p. 155-167.

Zhang, Q., and Zhang, X., 2012, Impacts of predictor variables and species models on simulating Tamarix ramosissima distribution in Tarim Basin, northwestern China: Journal of Plant Ecology, v. 5, p. 337-345. 


\section{Appendix 1. Temperature and Day-Length Data for Study Sites in the Colorado River basin, 2011-12}

\section{Temperature Data, 2011-12}

Temperature data are from records supplied by the National Oceanic and Atmospheric Administration (NOAA)'s National Environmental Satellite, Data, and Information Service (http://www.ncdc.noaa.gov/cdo-web/search) for the spring months (March 1-June 30) in 2011 and 2012. For the Marble Canyon study site, we used the data from station

GHCND:USW00053164 (PAGE 9 WSW AZ US, elev $991.8 \mathrm{~m}$, lat $36.8637^{\circ} \mathrm{N}$, long $111.6012^{\circ}$ W) in Lees Ferry, Arizona; for the Grand Canyon study site, we used the data from station GHCND:USC00026471 (PHANTOM RANCH AZ US, elev $771.1 \mathrm{~m}$, lat $36.1383^{\circ} \mathrm{N}$, long $112.0958^{\circ} \mathrm{W}$ ) in Phantom Ranch, Arizona; and for the San Juan study site, we used the data from station GHCND:USC00293142 (FARMINGTON AG SCIENCE CNT NM US, elev $1,714.5 \mathrm{~m}$, lat $36.6897^{\circ} \mathrm{N}$, long $108.3086^{\circ} \mathrm{W}$ ) in Farmington, New Mexico. Dates are listed in "yyyymmdd" format; $T_{\max }$ and $T_{\min }$, maximum and minimum temperature, respectively, on each day.

Temperature Data for the Marble Canyon Study Site from Lees Ferry, Ariz., 2011

\begin{tabular}{clr}
\hline Date & $T_{\max }$ & $T_{\min }$ \\
\hline 20110301 & 15.5 & 0.4 \\
20110302 & 18.4 & 2.7 \\
20110303 & 20.6 & 5 \\
20110304 & 16.9 & 7.3 \\
20110305 & 18 & 1.5 \\
20110306 & 17.2 & 4.3 \\
20110307 & 15.6 & 7.5 \\
20110308 & 14.8 & 5.3 \\
20110309 & 17.3 & 2.9 \\
20110310 & 19.5 & 3.6 \\
20110311 & 22.8 & 4.1 \\
20110312 & 24.8 & 6.3 \\
20110313 & 20.7 & 8 \\
20110314 & 23.8 & 6.7 \\
20110315 & 24.1 & 8.9 \\
20110316 & 27.2 & 8.5 \\
20110317 & 23.5 & 13.6 \\
20110318 & 23.9 & 7.7 \\
20110319 & 22.1 & 9.7 \\
20110320 & 19.3 & 9.9
\end{tabular}




\begin{tabular}{|c|c|c|}
\hline Date & $T_{\max }$ & $T_{\min }$ \\
\hline 20110321 & 17.7 & 4.8 \\
\hline 20110322 & 13.6 & 3.2 \\
\hline 20110323 & 17.1 & 2.1 \\
\hline 20110324 & 18.6 & 7.3 \\
\hline 20110325 & 18.3 & 6.1 \\
\hline 20110326 & 11.3 & 5.8 \\
\hline 20110327 & 20.1 & 2.7 \\
\hline 20110328 & 23.3 & 7.1 \\
\hline 20110329 & 17.7 & 8.1 \\
\hline 20110330 & 24.2 & 6.5 \\
\hline 20110331 & 28.6 & 14.6 \\
\hline 20110401 & 29.8 & 9.7 \\
\hline 20110402 & 31.3 & 10.4 \\
\hline 20110403 & 23 & 8.3 \\
\hline 20110404 & 17.3 & 4.1 \\
\hline 20110405 & 25.9 & 4.7 \\
\hline 20110406 & 20.2 & 9.8 \\
\hline 20110407 & 22 & 6.9 \\
\hline 20110408 & 16.9 & 6.8 \\
\hline 20110409 & 11.2 & 3.8 \\
\hline 20110410 & 15.8 & 1.8 \\
\hline 20110411 & 19.5 & 3.2 \\
\hline 20110412 & 24.8 & 8.5 \\
\hline 20110413 & 24.5 & 8.7 \\
\hline 20110414 & 19.9 & 9.4 \\
\hline 20110415 & 21.4 & 8.3 \\
\hline 20110416 & 27.8 & 7.6 \\
\hline 20110417 & 31 & 11.8 \\
\hline 20110418 & 28.3 & 16.6 \\
\hline 20110419 & 27.1 & 10.5 \\
\hline 20110420 & 28.8 & 11.7 \\
\hline 20110421 & 28.4 & 14.4 \\
\hline 20110422 & 24.5 & 13.8 \\
\hline 20110423 & 21.7 & 13.6 \\
\hline 20110424 & 23.4 & 11 \\
\hline 20110425 & 24.7 & 8.3 \\
\hline 20110426 & 20 & 11.1 \\
\hline 20110427 & 19.5 & 7.2 \\
\hline 20110428 & 28.7 & 6.5 \\
\hline 20110429 & 23.9 & 8.6 \\
\hline 20110430 & 15.5 & 6.3 \\
\hline 20110501 & 17.6 & 8.1 \\
\hline
\end{tabular}




\begin{tabular}{clr}
\hline Date & $T_{\max }$ & \multicolumn{1}{c}{$T_{\min }$} \\
\hline 20110502 & 20.7 & 6.7 \\
20110503 & 28.2 & 6.3 \\
20110504 & 30 & 15.5 \\
20110505 & 29 & 11.9 \\
20110506 & 33.5 & 12.3 \\
20110507 & 33.3 & 15.5 \\
20110508 & 30.8 & 18.8 \\
20110509 & 21.2 & 10.2 \\
20110510 & 16.8 & 7.9 \\
20110511 & 21.3 & 12.6 \\
20110512 & 28.9 & 9.3 \\
20110513 & 29.7 & 13.8 \\
20110514 & 30.5 & 15.5 \\
20110515 & 30.8 & 16.9 \\
20110516 & 26.3 & 16.2 \\
20110517 & 24.4 & 13.3 \\
20110518 & 19.5 & 12.7 \\
20110519 & 19.3 & 11.4 \\
20110520 & 22.5 & 10 \\
20110521 & 28.1 & 9.5 \\
20110522 & 30.7 & 13.5 \\
20110523 & 29 & 17 \\
20110524 & 26 & 14.7 \\
20110525 & 29.4 & 12.9 \\
20110526 & 32.7 & 18.3 \\
20110527 & 35.5 & 15.6 \\
20110528 & 35.6 & 17.7 \\
20110529 & 28 & 13.2 \\
20110530 & 24.8 & 11.9 \\
20110531 & 33.1 & 10.3 \\
20110601 & 33.4 & 19.1 \\
20110602 & 30.2 & 16.8 \\
20110603 & 29.7 & 13.4 \\
20110604 & 35.6 & 13.2 \\
20110605 & 37.5 & 15.4 \\
20110606 & 33.7 & 18.5 \\
20110607 & 31.6 & 14.5 \\
20110608 & 33.1 & 16.4 \\
20110609 & 33.6 & 16.2 \\
20110610 & 35.5 & 17.4 \\
20110611 & 35 & 19.4 \\
20110612 & 34.5 & 17.3
\end{tabular}




\begin{tabular}{clr}
\hline Date & $T_{\max }$ & $T_{\min }$ \\
\hline 20110613 & 34.8 & 17.5 \\
20110614 & 37.1 & 19 \\
20110615 & 39.1 & 20.5 \\
20110616 & 38 & 25.9 \\
20110617 & 33.1 & 22.4 \\
20110618 & 36.3 & 18.5 \\
20110619 & 31.3 & 20.6 \\
20110620 & 31.4 & 18.5 \\
20110621 & 35.1 & 20.8 \\
20110622 & 39 & 18.4 \\
20110623 & 40.8 & 21.1 \\
20110624 & 40.7 & 25.5 \\
20110625 & 40.5 & 23.3 \\
20110626 & 39.6 & 21.4 \\
20110627 & 41.6 & 19.7 \\
20110628 & 41.3 & 22.5 \\
20110629 & 40.7 & 28.7 \\
20110630 & 34.9 & 26.5 \\
\hline
\end{tabular}

Temperature Data for the Marble Canyon Study Site from Lees Ferry, Ariz., 2012

\begin{tabular}{ccr}
\hline Date & $T_{\max }$ & $T_{\min }$ \\
\hline 20120301 & 12.7 & 2.2 \\
20120302 & 10.6 & 1.8 \\
20120303 & 12.8 & 0.2 \\
20120304 & 17.1 & 0.8 \\
20120305 & 19 & 1.4 \\
20120306 & 24.3 & 4.3 \\
20120307 & 13.4 & 4.5 \\
20120308 & 16.8 & 4.5 \\
20120309 & 17.5 & 1.5 \\
20120310 & 18.5 & 3.1 \\
20120311 & 22.8 & 4 \\
20120312 & 21.9 & 10.9 \\
20120313 & 25.5 & 4.7 \\
20120314 & 22.7 & 5.5 \\
20120315 & 25 & 6.6 \\
20120316 & 26.4 & 6.6 \\
20120317 & 23.4 & 14.8 \\
20120318 & 15.2 & 3.8
\end{tabular}




\begin{tabular}{ccr}
\hline Date & $T_{\max }$ & $T_{\min }$ \\
\hline 20120319 & 11.2 & 2.9 \\
20120320 & 14.2 & 4 \\
20120321 & 20.1 & 4.1 \\
20120322 & 23.9 & 5.1 \\
20120323 & 26.6 & 6.8 \\
20120324 & 25.4 & 9 \\
20120325 & 26.2 & 11.3 \\
20120326 & 21.3 & 12.3 \\
20120327 & 22.7 & 7.7 \\
20120328 & 26.3 & 7.5 \\
20120329 & 25.6 & 10.4 \\
20120330 & 28.1 & 9.1 \\
20120331 & 30.3 & 11.1 \\
20120401 & 20.1 & 10.5 \\
20120402 & 18.4 & 7.7 \\
20120403 & 22.7 & 7.9 \\
20120404 & 26.9 & 7.9 \\
20120405 & 26.1 & 10.1 \\
20120406 & 18.4 & 10.3 \\
20120407 & 20.3 & 4 \\
20120408 & 25.4 & 4.9 \\
20120409 & 29.6 & 7.7 \\
20120410 & 29.9 & 9.2 \\
20120411 & 25.9 & 12.2 \\
20120412 & 20.4 & 12 \\
20120413 & 17.8 & 10.2 \\
20120414 & 12.9 & 4 \\
20120415 & 21.2 & 7.1 \\
20120416 & 22.9 & 9.5 \\
20120417 & 26.5 & 8.7 \\
20120418 & 30.5 & 10.2 \\
20120419 & 30.1 & 14.9 \\
20120420 & 28.2 & 13.7 \\
20120421 & 31.7 & 12.7 \\
20120422 & 34.1 & 13.8 \\
20120423 & 35.1 & 15.3 \\
20424 & 34.7 & 15.7 \\
20425 & 27.6 & 18.8 \\
24.8 & 15.5 \\
26.2 & 13.9
\end{tabular}




\begin{tabular}{ccc}
\hline Date & $T_{\max }$ & $T_{\min }$ \\
\hline 20120428 & 25.4 & 16.5 \\
20120429 & 25.1 & 14.9 \\
20120430 & 30.9 & 11.2 \\
20120501 & 31.5 & 17.9 \\
20120502 & 29.6 & 19.2 \\
20120503 & 31.8 & 14.4 \\
20120504 & 33.1 & 14.2 \\
20120505 & 29.3 & 16.2 \\
20120506 & 27.1 & 15.7 \\
20120507 & 25.7 & 16.1 \\
20120508 & 27.5 & 17.5 \\
20120509 & 29.9 & 13.5 \\
20120510 & 34.4 & 14.1 \\
20120511 & 33.3 & 17.7 \\
20120512 & 32.6 & 17.6 \\
20120513 & 32.5 & 15.8 \\
20120514 & 31.4 & 14.1 \\
20120515 & 35.5 & 14.3 \\
20120516 & 34.5 & 21.4 \\
20120517 & 37.4 & 16.2 \\
20120518 & 31 & 20.4 \\
20120519 & 28.9 & 16.1 \\
20120520 & 33.7 & 14.5 \\
20120521 & 38 & 15.6 \\
20120522 & 38.3 & 20.7 \\
20120523 & 35.6 & 23.7 \\
20120524 & 32.4 & 19.1 \\
20120525 & 32.8 & 22.6 \\
20120526 & 23.4 & 17 \\
20120527 & 26.2 & 11.9 \\
20120528 & 29.2 & 12.5 \\
20120529 & 34.5 & 13.6 \\
20120530 & 35 & 16.2 \\
20120531 & 35.8 & 19.4 \\
20120601 & 38.3 & 19.5 \\
201206062 & 39.4 & 22.4 \\
39.7 & 21.8 \\
20605 & 38.4 & 21.9 \\
25.7 & 22.8 \\
23.6 & 19.2
\end{tabular}




\begin{tabular}{ccc}
\hline Date & $T_{\max }$ & $T_{\min }$ \\
\hline 20120607 & 34.5 & 18.3 \\
20120608 & 38 & 18.9 \\
20120609 & 38 & 22.1 \\
20120610 & 30.5 & 17.8 \\
20120611 & 33.6 & 17.4 \\
20120612 & 37.8 & 16.9 \\
20120613 & 38.4 & 18.1 \\
20120614 & 38 & 21.6 \\
20120615 & 37.2 & 22.6 \\
20120616 & 38.4 & 20.3 \\
20120617 & 40.1 & 20.6 \\
20120618 & 40 & 24.6 \\
20120619 & 40.2 & 20.9 \\
20120620 & 38.2 & 26.1 \\
20120621 & 42.5 & 20.8 \\
20120622 & 40.6 & 23.5 \\
20120623 & 41 & 20.8 \\
20120624 & 41.3 & 22.5 \\
20120625 & 40.3 & 25.6 \\
20120626 & 39.9 & 23.3 \\
20120627 & 40.3 & 25 \\
20120628 & 40.6 & 25.1 \\
20120629 & 41.3 & 25 \\
20120630 & 41.7 & 24.5 \\
\hline & & \\
\hline
\end{tabular}

Temperature Data for the Grand Canyon Study Site from Phantom Ranch, Ariz., 2011

\begin{tabular}{ccc}
\hline Date & $T_{\max }$ & $T_{\min }$ \\
\hline 20110301 & 17.8 & 1.7 \\
20110302 & 19.4 & 3.9 \\
20110303 & 22.8 & 6.7 \\
20110304 & 21.1 & 5.6 \\
20110305 & 21.1 & 3.9 \\
20110306 & 22.2 & 5.6 \\
20110307 & 21.1 & 9.4 \\
20110308 & 15.6 & 5 \\
20110309 & 20.6 & 3.3 \\
20110310 & 22.2 & 6.1 \\
20110311 & 26.7 & 6.1 \\
20110312 & 27.2 & 10.6
\end{tabular}




\begin{tabular}{ccc}
\hline Date & $\boldsymbol{T}_{\max }$ & $\boldsymbol{T}_{\min }$ \\
\hline 20110313 & 25.6 & 8.9 \\
20110314 & 25.6 & 9.4 \\
20110315 & 26.7 & 11.1 \\
20110316 & 28.3 & 11.1 \\
20110317 & 26.7 & 13.9 \\
20110318 & 26.1 & 8.9 \\
20110319 & 26.1 & 8.9 \\
20110320 & 22.8 & 12.2 \\
20110321 & 20.6 & 7.2 \\
20110322 & 16.1 & 5.6 \\
20110323 & 20 & 3.9 \\
20110324 & 20 & 9.4 \\
20110325 & 18.3 & 9.4 \\
20110326 & 16.7 & 6.1 \\
20110327 & 22.2 & 7.8 \\
20110328 & 25.6 & 10 \\
20110329 & 22.2 & 11.1 \\
20110330 & 25.6 & 8.3 \\
20110331 & 29.4 & 12.2 \\
20110401 & 32.2 & 11.7 \\
20110402 & 33.3 & 12.2 \\
20110403 & 31.7 & 17.8 \\
20110404 & 21.1 & 8.9 \\
20110405 & 30.6 & 7.8 \\
20110406 & 25 & 11.1 \\
20110407 & 23.9 & 9.4 \\
20110408 & 20 & 7.2 \\
20110409 & 11.7 & 3.9 \\
20110410 & 16.1 & 4.4 \\
20110411 & 22.8 & 5 \\
20110412 & 26.7 & 9.4 \\
20110413 & 26.7 & 10 \\
20110414 & 21.7 & 10 \\
20110415 & 25.6 & 7.8 \\
20110416 & 29.4 & 9.4 \\
20110417 & 33.9 & 12.8 \\
20110418 & 29.4 & 17.2 \\
20110419 & 30.6 & 16.7 \\
20110420 & 31.7 & 16.1 \\
20110421 & 30 & 18.3 \\
20110422 & 29.4 & 13.9 \\
20110423 & 26.7 & 18.3
\end{tabular}




\begin{tabular}{clc}
\hline Date & $T_{\max }$ & $T_{\min }$ \\
\hline 20110424 & 27.2 & 15.6 \\
20110425 & 27.8 & 15 \\
20110426 & 26.1 & 16.1 \\
20110427 & 25 & 9.4 \\
20110428 & 32.2 & 10 \\
20110429 & 31.7 & 19.4 \\
20110430 & 23.3 & 8.3 \\
20110501 & 20 & 8.3 \\
20110502 & 25 & 7.2 \\
20110503 & 31.1 & 8.9 \\
20110504 & 32.8 & 12.2 \\
20110511 & 25.6 & 13.9 \\
20110512 & 31.7 & 12.8 \\
20110517 & 25.6 & 13.9 \\
20110518 & 23.3 & 11.1 \\
20110519 & 23.9 & 9.4 \\
20110520 & 26.1 & 12.8 \\
20110521 & 31.1 & 11.7 \\
20110522 & 32.8 & 15.6 \\
20110523 & 30.6 & 18.3 \\
20110524 & 30.6 & 15.6 \\
20110525 & 35 & 16.1 \\
20110526 & 35.6 & 21.7 \\
20110527 & 38.3 & 17.2 \\
20110528 & 36.7 & 20 \\
20110529 & 32.2 & 20.6 \\
20110530 & 27.2 & 13.9 \\
20110531 & 36.1 & 12.8 \\
20110601 & 35.6 & 17.8 \\
20110602 & 32.8 & 16.7 \\
20110603 & 33.9 & 16.7 \\
20110604 & 37.2 & 15.6 \\
20110605 & 38.9 & 17.2 \\
20110606 & 36.1 & 19.4 \\
20110607 & 36.1 & 16.1 \\
20110608 & 34.4 & 17.2 \\
20110609 & 35.6 & 16.7 \\
20110610 & 38.9 & 18.3 \\
20110611 & 36.7 & 21.1 \\
20110612 & 36.1 & 18.9 \\
20110613 & 37.2 & 17.8 \\
20110614 & 39.4 & 20.6
\end{tabular}




\begin{tabular}{ccl}
\hline Date & $\boldsymbol{T}_{\max }$ & $\boldsymbol{T}_{\min }$ \\
\hline 20110615 & 42.2 & 20.6 \\
20110616 & 39.4 & 26.1 \\
20110617 & 34.4 & 21.7 \\
20110618 & 38.9 & 18.9 \\
20110619 & 35.6 & 18.3 \\
20110620 & 35.6 & 18.3 \\
20110621 & 39.4 & 19.4 \\
20110622 & 43.9 & 20.6 \\
20110623 & 43.3 & 22.8 \\
20110624 & 42.8 & 25 \\
20110625 & 41.7 & 22.8 \\
20110626 & 41.7 & 23.3 \\
20110627 & 43.3 & 21.1 \\
20110628 & 43.3 & 23.9 \\
20110629 & 40.6 & 30 \\
20110630 & 38.3 & 25.6 \\
\hline
\end{tabular}

Temperature Data for the Grand Canyon Study Site from Phantom Ranch, Ariz., 2012

\begin{tabular}{ccc}
\hline Date & $\boldsymbol{T}_{\max }$ & $\boldsymbol{T}_{\min }$ \\
\hline 20120301 & 16.1 & 5.6 \\
20120302 & 13.9 & 3.3 \\
20120303 & 16.7 & 1.1 \\
20120304 & 21.1 & 2.8 \\
20120305 & 22.2 & 3.9 \\
20120306 & 25.6 & 6.7 \\
20120307 & 21.7 & 5 \\
20120308 & 19.4 & 3.3 \\
20120309 & 21.1 & 4.4 \\
20120310 & 21.7 & 7.8 \\
20120311 & 26.7 & 8.9 \\
20120312 & 25.6 & 8.3 \\
20120313 & 27.8 & 7.2 \\
20120314 & 26.7 & 8.3 \\
20120315 & 27.8 & 9.4 \\
20120316 & 29.4 & 10.6 \\
20120317 & 25.6 & 14.4 \\
20120318 & 20 & 5.6 \\
20120319 & 11.1 & 4.4 \\
20120320 & 16.1 & 5 \\
20120321 & 21.7 & 5
\end{tabular}




\begin{tabular}{crc}
\hline Date & $T_{\max }$ & $\boldsymbol{T}_{\min }$ \\
\hline 20120322 & 26.1 & 6.7 \\
20120323 & 28.3 & 9.4 \\
20120324 & 27.8 & 10.6 \\
20120325 & 27.8 & 12.2 \\
20120326 & 23.9 & 9.4 \\
20120327 & 26.7 & 8.3 \\
20120328 & 27.8 & 10.6 \\
20120329 & 27.8 & 10.6 \\
20120330 & 28.9 & 12.2 \\
20120331 & 31.7 & 13.9 \\
20120401 & 27.8 & 11.7 \\
20120402 & 19.4 & 8.9 \\
20120403 & 23.9 & 9.4 \\
20120404 & 28.9 & 10.6 \\
20120405 & 27.2 & 13.9 \\
20120406 & 22.2 & 12.8 \\
20120407 & 26.1 & 9.4 \\
20120408 & 30 & 10.6 \\
20120409 & 33.3 & 11.1 \\
20120410 & 33.3 & 12.2 \\
20120411 & 21.1 & 14.4 \\
20120412 & 22.8 & 12.8 \\
20120413 & 20 & 13.3 \\
20120414 & 17.2 & 6.7 \\
20120415 & 20.6 & 7.2 \\
20120416 & 25 & 8.3 \\
20120417 & 30 & 10 \\
20120418 & 32.2 & 12.2 \\
20120419 & 32.2 & 13.9 \\
20120420 & 32.2 & 15 \\
20120421 & 36.1 & 14.4 \\
20120422 & 38.3 & 16.1 \\
20120423 & 37.8 & 17.2 \\
20120424 & 36.7 & 16.7 \\
20120425 & 30 & 20 \\
20120426 & 27.8 & 17.8 \\
20120427 & 28.3 & 17.2 \\
20120428 & 28.9 & 17.2 \\
& 30.6 & 16.7 \\
20120402 & 33.9 & 13.9 \\
32.2 & 18.3 \\
2.2 & 17.8
\end{tabular}




\begin{tabular}{ccc}
\hline Date & $T_{\max }$ & $\boldsymbol{T}_{\min }$ \\
\hline 20120503 & 33.3 & 17.2 \\
20120504 & 35 & 16.1 \\
20120505 & 34.4 & 16.1 \\
20120506 & 31.1 & 16.1 \\
20120507 & 31.1 & 15.6 \\
20120508 & 31.1 & 15.6 \\
20120509 & 32.2 & 13.9 \\
20120510 & 36.1 & 17.8 \\
20120511 & 36.7 & 18.3 \\
20120512 & 36.7 & 17.8 \\
20120513 & 35.6 & 17.8 \\
20120514 & 36.1 & 16.7 \\
20120515 & 38.9 & 19.4 \\
20120516 & 37.2 & 19.4 \\
20120517 & 39.4 & 18.3 \\
20120518 & 33.3 & 23.9 \\
20120519 & 34.4 & 18.9 \\
20120520 & 37.8 & 16.7 \\
20120521 & 40.6 & 18.9 \\
20120522 & 40.6 & 21.1 \\
20120523 & 39.4 & 22.2 \\
20120524 & 36.7 & 22.2 \\
20120525 & 32.8 & 21.7 \\
20120526 & 29.4 & 17.8 \\
20120527 & 28.9 & 13.9 \\
20120528 & 34.4 & 15 \\
20120529 & 37.8 & 17.2 \\
20120530 & 37.8 & 17.8 \\
20120531 & 40 & 17.8 \\
20120601 & 43.3 & 21.1 \\
20120602 & 41.7 & 23.9 \\
20120603 & 41.7 & 22.2 \\
20120604 & 40 & 22.2 \\
20120605 & 37.8 & 23.3 \\
20120606 & 37.8 & 18.9 \\
20120607 & 39.4 & 20 \\
20120608 & 40 & 21.1 \\
& 39.4 & 23.3 \\
20120613 & 41.1 & 21.1
\end{tabular}




\begin{tabular}{ccc}
\hline Date & $T_{\max }$ & $T_{\min }$ \\
\hline 20120614 & 40.6 & 22.8 \\
20120615 & 39.4 & 21.7 \\
20120616 & 41.7 & 21.7 \\
20120617 & 42.2 & 25 \\
20120618 & 41.7 & 25 \\
20120619 & 42.2 & 20 \\
20120620 & 43.3 & 22.8 \\
20120621 & 44.4 & 25 \\
20120622 & 42.2 & 24.4 \\
20120623 & 42.2 & 22.2 \\
20120624 & 42.8 & 25 \\
20120625 & 41.7 & 27.8 \\
20120626 & 40.6 & 26.1 \\
20120627 & 42.2 & 26.1 \\
20120628 & 42.2 & 27.8 \\
20120629 & 43.9 & 27.2 \\
20120630 & 43.9 & 26.1 \\
\hline
\end{tabular}

Temperature Data for the San Juan Study Site from Farmington, N. Mex., 2011

\begin{tabular}{ccc}
\hline Date & $T_{\max }$ & $T_{\min }$ \\
\hline 20110301 & 10.6 & -6.7 \\
20110302 & 15 & 0 \\
20110303 & 16.7 & 1.7 \\
20110304 & 16.7 & 0 \\
20110305 & 11.1 & -6.7 \\
20110306 & 12.2 & -3.3 \\
20110307 & 10 & 0.6 \\
20110308 & 8.9 & -1.7 \\
20110309 & 6.1 & -4.4 \\
20110310 & 12.2 & -1.7 \\
20110311 & 15.6 & 0.6 \\
20110312 & 19.4 & 2.2 \\
20110313 & 18.9 & 1.7 \\
20110314 & 15.6 & 0.6 \\
20110315 & 18.3 & 0 \\
20110316 & 18.9 & 1.1 \\
20110317 & 22.8 & 3.9 \\
20110318 & 20.6 & 1.1 \\
20110319 & 18.9 & 1.7 \\
20110320 & 20.6 & 3.9
\end{tabular}




\begin{tabular}{ccc}
\hline Date & $T_{\max }$ & $T_{\min }$ \\
\hline 20110321 & 16.1 & 5 \\
20110322 & 19.4 & 0 \\
20110323 & 8.9 & -5 \\
20110324 & 12.8 & -3.3 \\
20110325 & 13.3 & -3.9 \\
20110326 & 15 & -3.3 \\
20110327 & 13.3 & 0 \\
20110328 & 15.6 & 0.6 \\
20110329 & 17.8 & -1.1 \\
20110330 & 13.9 & -2.2 \\
20110331 & 15.6 & -1.7 \\
20110401 & 21.1 & 2.8 \\
20110402 & 23.3 & 6.1 \\
20110403 & 26.1 & 9.4 \\
20110404 & 18.9 & -3.9 \\
20110405 & 11.7 & -3.9 \\
20110406 & 21.1 & 0.6 \\
20110407 & 18.9 & 4.4 \\
20110408 & 17.2 & 3.9 \\
20110409 & 20.6 & 6.1 \\
20110410 & 15 & -6.1 \\
20110411 & 10 & -3.3 \\
20110412 & 15.6 & 3.3 \\
20110413 & 21.1 & 1.1 \\
20110414 & 20.6 & 2.2 \\
20110415 & 13.3 & -0.6 \\
20110416 & 7.8 & -0.6 \\
20110417 & 20.6 & 4.4 \\
20110418 & 24.4 & 6.1 \\
20110419 & 8.9 & 5.6 \\
20110420 & 20 & 6.1 \\
20110421 & 23.3 & 6.7 \\
20110422 & 23.3 & 2.8 \\
20110423 & 19.4 & 5 \\
20110424 & 18.9 & 5.6 \\
20110425 & 13.9 & 3.3 \\
20110426 & 15.6 & 3.9 \\
20110427 & 11.7 & -1.1 \\
20110428 & 11.7 & -1.7 \\
20110429 & 19.4 & 1.7 \\
20110430 & 22.8 & -2.2 \\
20110501 & 11.1 & -2.2
\end{tabular}




\begin{tabular}{ccc}
\hline Date & $T_{\max }$ & $T_{\min }$ \\
\hline 20110502 & 11.7 & -3.3 \\
20110503 & 13.9 & 0 \\
20110504 & 20.6 & 2.2 \\
20110505 & 23.3 & 1.1 \\
20110506 & 22.8 & 3.3 \\
20110507 & 26.7 & 5.6 \\
20110508 & 27.8 & 7.2 \\
20110509 & 26.1 & 10 \\
20110510 & 19.4 & 2.2 \\
20110511 & 16.1 & 2.8 \\
20110512 & 16.1 & 3.3 \\
20110513 & 21.1 & 2.8 \\
20110514 & 25 & 6.1 \\
20110515 & 26.7 & 8.9 \\
20110516 & 26.7 & 7.8 \\
20110517 & 25.6 & 10 \\
20110518 & 20.6 & 7.8 \\
20110519 & 13.9 & 3.3 \\
20110520 & 12.2 & 4.4 \\
20110521 & 17.2 & 3.3 \\
20110522 & 19.4 & 7.8 \\
20110523 & 23.9 & 8.9 \\
20110524 & 23.9 & 7.8 \\
20110525 & 18.9 & 4.4 \\
20110526 & 21.7 & 7.2 \\
20110527 & 26.7 & 9.4 \\
20110528 & 27.2 & 13.9 \\
20110529 & 30.6 & 14.4 \\
20110530 & 28.9 & 5.6 \\
20110531 & 18.9 & 6.7 \\
20110601 & 28.9 & 10.6 \\
20110602 & 30 & 13.3 \\
20110603 & 29.4 & 8.9 \\
20110604 & 28.3 & 11.7 \\
20110605 & 31.1 & 13.3 \\
20110606 & 32.2 & 13.9 \\
20110607 & 31.7 & 8.3 \\
20110608 & 27.2 & 10 \\
20110609 & 30.6 & 8.9 \\
20110610 & 26.7 & 8.9 \\
20110611 & 28.3 & 12.2 \\
20110612 & 30 & 10
\end{tabular}




\begin{tabular}{ccc}
\hline Date & $\boldsymbol{T}_{\max }$ & $\boldsymbol{T}_{\min }$ \\
\hline 20110613 & 28.9 & 12.8 \\
20110614 & 30 & 10 \\
20110615 & 29.4 & 10.6 \\
20110616 & 32.2 & 14.4 \\
20110617 & 32.2 & 14.4 \\
20110618 & 29.4 & 15 \\
20110619 & 30 & 13.3 \\
20110620 & 28.9 & 8.9 \\
20110621 & 25.6 & 7.8 \\
20110622 & 28.3 & 10.6 \\
20110623 & 31.7 & 13.9 \\
20110624 & 35 & 16.1 \\
20110625 & 33.3 & 15 \\
20110626 & 33.3 & 15.6 \\
20110627 & 33.3 & 13.3 \\
20110628 & 35 & 18.9 \\
20110629 & 33.9 & 18.9 \\
20110630 & 35.6 & 18.9 \\
\hline
\end{tabular}

Temperature Data for the San Juan Study Site from Farmington, N. Mex., 2012

\begin{tabular}{ccc}
\hline Date & $T_{\max }$ & $T_{\min }$ \\
\hline 20120301 & 8.9 & -3.3 \\
20120302 & 9.4 & -6.1 \\
20120303 & 11.7 & -10.6 \\
20120304 & 3.3 & -6.7 \\
20120305 & 10 & -2.2 \\
20120306 & 15.6 & -1.1 \\
20120307 & 17.2 & 2.2 \\
20120308 & 9.4 & -2.2 \\
20120309 & 10 & -4.4 \\
20120310 & 10.6 & -3.3 \\
20120311 & 8.9 & -2.2 \\
20120312 & 16.1 & -1.1 \\
20120313 & 15.6 & 0 \\
20120314 & 19.4 & 0 \\
20120315 & 18.3 & 0 \\
20120317 & 21.1 & 2.8 \\
20120318 & 20 & 3.3 \\
20120319 & 7.2 & -5 \\
20120320 & 2.2 & -5
\end{tabular}




\begin{tabular}{ccc}
\hline Date & $T_{\max }$ & $T_{\min }$ \\
\hline 20120321 & 14.4 & -4.4 \\
20120322 & 20 & -3.9 \\
20120323 & 19.4 & -3.3 \\
20120324 & 22.8 & 2.8 \\
20120325 & 22.8 & 6.7 \\
20120326 & 22.8 & 5 \\
20120327 & 20.6 & -0.6 \\
20120329 & 22.2 & 3.3 \\
20120330 & 20.6 & 2.2 \\
20120331 & 22.2 & 2.8 \\
20120401 & 25.6 & 6.1 \\
20120402 & 22.8 & 0.6 \\
20120403 & 8.3 & -1.1 \\
20120404 & 15 & -2.2 \\
20120405 & 20 & 0.6 \\
20120406 & 20.6 & 3.3 \\
20120407 & 18.3 & -3.9 \\
20120408 & 17.8 & 2.8 \\
20120409 & 23.3 & 3.3 \\
20120410 & 25.6 & 7.8 \\
20120411 & 26.7 & 8.9 \\
20120412 & 26.1 & 4.4 \\
20120413 & 16.1 & 0 \\
20120414 & 13.9 & 2.2 \\
20120415 & 10 & -1.1 \\
20120416 & 13.3 & -2.8 \\
20120417 & 15.6 & 1.1 \\
20120418 & 21.1 & 3.9 \\
20120419 & 23.3 & 6.1 \\
20120420 & 20.6 & 2.8 \\
20120421 & 22.8 & 3.9 \\
20120422 & 26.7 & 7.8 \\
20120423 & 27.8 & 9.4 \\
20120424 & 28.9 & 11.1 \\
20120425 & 29.4 & 10 \\
20120426 & 25.6 & 10.6 \\
20120427 & 26.7 & 6.1 \\
20120428 & 20 & 3.9 \\
20120430 & 21.7 & 3.3 \\
& 23.9 & 7.2 \\
23.9 & 5 \\
24.4 & 6.1
\end{tabular}




\begin{tabular}{ccc}
\hline Date & $T_{\max }$ & $T_{\min }$ \\
\hline 20120504 & 26.1 & 7.8 \\
20120505 & 27.8 & 7.8 \\
20120506 & 25.6 & 5.6 \\
20120507 & 24.4 & 6.1 \\
20120508 & 22.2 & 2.8 \\
20120509 & 21.7 & 7.8 \\
20120510 & 23.3 & 7.2 \\
20120511 & 26.7 & 7.2 \\
20120512 & 27.8 & 9.4 \\
20120513 & 25.6 & 10.6 \\
20120514 & 22.8 & 3.9 \\
20120515 & 23.3 & 9.4 \\
20120516 & 28.3 & 12.8 \\
20120517 & 28.3 & 10.6 \\
20120518 & 28.9 & 13.3 \\
20120519 & 26.7 & 6.7 \\
20120520 & 23.3 & 6.7 \\
20120521 & 27.2 & 10 \\
20120522 & 30.6 & 12.8 \\
20120523 & 30.6 & 10 \\
20120524 & 30 & 7.8 \\
20120525 & 24.4 & 11.7 \\
20120526 & 29.4 & 13.3 \\
20120527 & 27.8 & 2.8 \\
20120528 & 20 & 2.8 \\
20120529 & 23.3 & 8.3 \\
20120530 & 28.9 & 8.3 \\
20120531 & 28.3 & 9.4 \\
20120601 & 30.6 & 11.7 \\
20120602 & 27.8 & 14.4 \\
20120603 & 32.2 & 13.3 \\
20120604 & 32.2 & 17.2 \\
20120605 & 33.3 & 13.3 \\
20120606 & 31.7 & 11.7 \\
20120607 & 31.1 & 12.2 \\
20120608 & 30.6 & 12.2 \\
20120609 & 32.2 & 12.8 \\
20120610 & 31.1 & 13.3 \\
20120611 & 25.6 & 7.2 \\
20120612 & 28.9 & 10 \\
20120613 & 31.7 & 12.8 \\
20120614 & 33.3 & 12.8
\end{tabular}




\begin{tabular}{cll}
\hline Date & $T_{\max }$ & $T_{\min }$ \\
\hline 20120615 & 31.7 & 13.9 \\
20120616 & 31.7 & 13.9 \\
20120617 & 31.7 & 14.4 \\
20120618 & 32.8 & 13.9 \\
20120619 & 32.8 & 12.8 \\
20120620 & 32.2 & 14.4 \\
20120621 & 31.7 & 12.2 \\
20120622 & 35 & 17.2 \\
20120623 & 36.1 & 16.1 \\
20120624 & 36.1 & 18.3 \\
20120625 & 36.7 & 18.9 \\
20120626 & 35 & 16.7 \\
20120627 & 34.4 & 18.3 \\
\hline
\end{tabular}




\section{Day-Length Data, 2011}

Day lengths are from the U.S. Naval Observatory sunrise/sunset tables (http://aa.usno.navy.mil).

\section{Day Lengths for the Marble Canyon Study Site from Lees Ferry, Ariz., 2011}

Location: w111 $35^{\prime}$, N36 $5 \dot{1}$
LEE'S FERRY, AZ
Universal Time
Astronomical Applications Dept. U. S. Naval Observatory

Washington, DC 20392-5420

Duration of Daylight for 2011

\begin{tabular}{|c|c|c|c|c|c|c|c|c|c|c|c|c|}
\hline Day & Jan. & Feb. & Mar. & Apr. & May & June & July & Aug. & Sep. & oct. & Nov. & Dec. \\
\hline & $\mathrm{h} \mathrm{m}$ & $\mathrm{h} \quad \mathrm{m}$ & $\mathrm{h} \mathrm{m}$ & $\mathrm{h} \mathrm{m}$ & $\mathrm{h} \mathrm{m}$ & $\mathrm{h} \mathrm{m}$ & $\mathrm{h} \mathrm{m}$ & $\mathrm{h} \mathrm{m}$ & $\mathrm{h} \mathrm{m}$ & $\mathrm{h} \mathrm{m}$ & $\mathrm{h} \mathrm{m}$ & $\mathrm{h} \quad \mathrm{m}$ \\
\hline 01 & $09: 41$ & $10: 22$ & $11: 22$ & $12: 35$ & $13: 41$ & $14: 30$ & $14: 39$ & $14: 02$ & $12: 59$ & $11: 50$ & $10: 40$ & $09: 50$ \\
\hline 02 & $09: 41$ & $10: 24$ & $11: 24$ & $12: 38$ & $13: 43$ & $14: 31$ & $14: 38$ & $14: 01$ & $12: 57$ & $11: 48$ & $10: 38$ & $09: 49$ \\
\hline 03 & $09: 42$ & $10: 26$ & $11: 27$ & $12: 40$ & $13: 45$ & $14: 32$ & $14: 38$ & $13: 59$ & $12: 55$ & $11: 45$ & $10: 36$ & $09: 48$ \\
\hline 04 & $09: 43$ & $10: 28$ & $11: 29$ & $12: 42$ & $13: 47$ & $14: 33$ & $14: 37$ & $13: 57$ & $12: 52$ & $11: 43$ & $10: 34$ & $09: 47$ \\
\hline 05 & $09: 44$ & $10: 30$ & $11: 31$ & $12: 45$ & $13: 49$ & $14: 34$ & $14: 36$ & $13: 55$ & $12: 50$ & $11: 41$ & $10: 32$ & $09: 46$ \\
\hline 06 & $09: 44$ & $10: 32$ & $11: 34$ & $12: 47$ & $13: 51$ & $14: 35$ & $14: 36$ & $13: 53$ & $12: 48$ & $11: 38$ & $10: 30$ & $09: 45$ \\
\hline 07 & $09: 45$ & $10: 34$ & $11: 36$ & $12: 49$ & $13: 53$ & $14: 36$ & $14: 35$ & $13: 51$ & $12: 46$ & $11: 36$ & $10: 28$ & $09: 44$ \\
\hline 08 & $09: 46$ & $10: 36$ & $11: 38$ & $12: 51$ & $13: 55$ & $14: 36$ & $14: 34$ & $13: 50$ & $12: 43$ & $11: 34$ & $10: 26$ & $09: 43$ \\
\hline 09 & $09: 47$ & $10: 38$ & $11: 41$ & $12: 54$ & $13: 57$ & $14: 37$ & $14: 33$ & $13: 48$ & $12: 41$ & $11: 31$ & $10: 24$ & $09: 42$ \\
\hline 10 & $09: 48$ & $10: 40$ & $11: 43$ & $12: 56$ & $13: 59$ & $14: 38$ & $14: 32$ & $13: 46$ & $12: 39$ & $11: 29$ & $10: 22$ & $09: 42$ \\
\hline 11 & $09: 49$ & $10: 42$ & $11: 46$ & $12: 58$ & $14: 00$ & $14: 38$ & $14: 31$ & $13: 44$ & $12: 37$ & $11: 27$ & $10: 21$ & $09: 41$ \\
\hline 12 & $09: 50$ & $10: 44$ & $11: 48$ & $13: 01$ & $14: 02$ & $14: 39$ & $14: 30$ & $13: 42$ & $12: 34$ & $11: 25$ & $10: 19$ & $09: 40$ \\
\hline 13 & $09: 52$ & $10: 46$ & $11: 50$ & $13: 03$ & $14: 04$ & $14: 39$ & $14: 29$ & $13: 40$ & $12: 32$ & $11: 22$ & $10: 17$ & $09: 40$ \\
\hline 14 & $09: 53$ & $10: 48$ & $11: 53$ & $13: 05$ & $14: 06$ & $14: 40$ & $14: 28$ & $13: 38$ & $12: 30$ & $11: 20$ & $10: 15$ & $09: 39$ \\
\hline 15 & $09: 54$ & $10: 51$ & $11: 55$ & $13: 07$ & $14: 07$ & $14: 40$ & $14: 27$ & $13: 36$ & $12: 27$ & $11: 18$ & $10: 13$ & $09: 39$ \\
\hline 16 & $09: 55$ & $10: 53$ & $11: 57$ & $13: 10$ & $14: 09$ & $14: 40$ & $14: 26$ & $13: 34$ & $12: 25$ & $11: 15$ & $10: 12$ & $09: 39$ \\
\hline 17 & $09: 57$ & $10: 55$ & $12: 00$ & $13: 12$ & $14: 11$ & $14: 41$ & $14: 25$ & $13: 32$ & $12: 23$ & $11: 13$ & $10: 10$ & $09: 38$ \\
\hline 18 & $09: 58$ & $10: 57$ & $12: 02$ & $13: 14$ & $14: 12$ & $14: 41$ & $14: 23$ & $13: 30$ & $12: 20$ & $11: 11$ & $10: 08$ & $09: 38$ \\
\hline 19 & $10: 00$ & $10: 59$ & $12: 05$ & $13: 16$ & $14: 14$ & $14: 41$ & $14: 22$ & $13: 27$ & $12: 18$ & $11: 09$ & $10: 07$ & $09: 38$ \\
\hline 20 & $10: 01$ & $11: 02$ & $12: 07$ & $13: 18$ & $14: 15$ & $14: 41$ & $14: 21$ & $13: 25$ & $12: 16$ & $11: 06$ & $10: 05$ & $09: 38$ \\
\hline 21 & $10: 03$ & $11: 04$ & $12: 09$ & $13: 21$ & $14: 17$ & $14: 41$ & $14: 20$ & $13: 23$ & $12: 13$ & $11: 04$ & $10: 03$ & $09: 38$ \\
\hline 22 & $10: 04$ & $11: 06$ & $12: 12$ & $13: 23$ & $14: 18$ & $14: 41$ & $14: 18$ & $13: 21$ & $12: 11$ & $11: 02$ & $10: 02$ & $09: 38$ \\
\hline 23 & $10: 06$ & $11: 08$ & $12: 14$ & $13: 25$ & $14: 20$ & $14: 41$ & $14: 17$ & $13: 19$ & $12: 09$ & $11: 00$ & $10: 00$ & $09: 38$ \\
\hline 24 & $10: 08$ & $11: 11$ & $12: 16$ & $13: 27$ & $14: 21$ & $14: 41$ & $14: 15$ & $13: 17$ & $12: 06$ & $10: 58$ & $09: 59$ & $09: 38$ \\
\hline 25 & $10: 09$ & $11: 13$ & $12: 19$ & $13: 29$ & $14: 22$ & $14: 41$ & $14: 14$ & $13: 15$ & $12: 04$ & $10: 55$ & $09: 58$ & $09: 38$ \\
\hline 26 & $10: 11$ & $11: 15$ & $12: 21$ & $13: 31$ & $14: 24$ & $14: 41$ & $14: 12$ & $13: 12$ & $12: 02$ & $10: 53$ & $09: 56$ & $09: 38$ \\
\hline 27 & $10: 13$ & $11: 17$ & $12: 23$ & $13: 33$ & $14: 25$ & $14: 40$ & $14: 11$ & $13: 10$ & $11: 59$ & $10: 51$ & $09: 55$ & $09: 38$ \\
\hline 28 & $10: 14$ & $11: 20$ & $12: 26$ & $13: 35$ & $14: 26$ & $14: 40$ & $14: 09$ & $13: 08$ & $11: 57$ & $10: 49$ & $09: 54$ & $09: 39$ \\
\hline 29 & $10: 16$ & & $12: 28$ & $13: 37$ & $14: 27$ & $14: 40$ & $14: 07$ & $13: 06$ & $11: 55$ & $10: 47$ & $09: 52$ & $09: 39$ \\
\hline 30 & $10: 18$ & & $12: 31$ & $13: 39$ & $14: 28$ & $14: 39$ & $14: 06$ & $13: 04$ & $11: 52$ & $10: 45$ & $09: 51$ & $09: 39$ \\
\hline 31 & $10: 20$ & & $12: 33$ & & $14: 29$ & & $14: 04$ & $13: 01$ & & $10: 42$ & & $09: 40$ \\
\hline
\end{tabular}




\section{Day Lengths for the Grand Canyon Study Site from Phantom Ranch, Ariz., 2011}

Location: w112 0, 120 , N36
PHANTOM RANCH, AZ

Universal Time
Astronomical Applications Dept. U. S. Naval Observatory Washington, DC 20392-5420

Duration of Daylight for 2011

\begin{tabular}{|c|c|c|c|c|c|c|c|c|c|c|c|c|}
\hline Day & Jan. & Feb. & Mar. & Apr. & May & June & July & Aug. & Sep. & oct. & Nov. & Dec. \\
\hline & $\mathrm{h} \mathrm{m}$ & $\mathrm{h} \quad \mathrm{m}$ & $\mathrm{h} \mathrm{m}$ & $\mathrm{h} \quad \mathrm{m}$ & $\mathrm{h} \mathrm{m}$ & $\mathrm{h} \mathrm{m}$ & $\mathrm{h} \quad \mathrm{m}$ & $\mathrm{h} \mathrm{m}$ & $\mathrm{h} \mathrm{m}$ & $\mathrm{h} \quad \mathrm{m}$ & $\mathrm{h} \mathrm{m}$ & $\mathrm{h}$ \\
\hline 01 & $09: 45$ & $10: 25$ & $11: 23$ & $12: 34$ & $13: 39$ & $14: 26$ & $14: 34$ & $13: 59$ & $12: 58$ & $11: 50$ & $10: 43$ & $09: 54$ \\
\hline 02 & $09: 45$ & $10: 27$ & $11: 26$ & $12: 37$ & $13: 41$ & $14: 27$ & $14: 34$ & $13: 57$ & $12: 56$ & $11: 48$ & $10: 41$ & $09: 53$ \\
\hline 03 & $09: 46$ & $10: 28$ & $11: 28$ & $12: 39$ & $13: 43$ & $14: 28$ & $14: 33$ & $13: 56$ & $12: 53$ & $11: 46$ & $10: 39$ & $09: 52$ \\
\hline 04 & $09: 47$ & $10: 30$ & $11: 30$ & $12: 41$ & $13: 45$ & $14: 29$ & $14: 33$ & $13: 54$ & $12: 51$ & $11: 44$ & $10: 37$ & $09: 51$ \\
\hline 05 & $09: 48$ & $10: 32$ & $11: 32$ & $12: 43$ & $13: 46$ & $14: 30$ & $14: 32$ & $13: 52$ & $12: 49$ & $11: 41$ & $10: 35$ & $09: 50$ \\
\hline 06 & $09: 48$ & $10: 34$ & $11: 35$ & $12: 46$ & $13: 48$ & $14: 31$ & $14: 31$ & $13: 50$ & $12: 47$ & $11: 39$ & $10: 33$ & $09: 49$ \\
\hline 07 & $09: 49$ & $10: 36$ & $11: 37$ & $12: 48$ & $13: 50$ & $14: 31$ & $14: 31$ & $13: 48$ & $12: 45$ & $11: 37$ & $10: 31$ & $09: 48$ \\
\hline 08 & $09: 50$ & $10: 38$ & $11: 39$ & $12: 50$ & $13: 52$ & $14: 32$ & $14: 30$ & $13: 47$ & $12: 42$ & $11: 35$ & $10: 29$ & $09: 47$ \\
\hline 09 & $09: 51$ & $10: 40$ & $11: 42$ & $12: 52$ & $13: 54$ & $14: 33$ & $14: 29$ & $13: 45$ & $12: 40$ & $11: 32$ & $10: 27$ & $09: 47$ \\
\hline 10 & $09: 52$ & $10: 42$ & $11: 44$ & $12: 55$ & $13: 55$ & $14: 33$ & $14: 28$ & $13: 43$ & $12: 38$ & $11: 30$ & $10: 25$ & $09: 46$ \\
\hline 11 & $09: 53$ & $10: 44$ & $11: 46$ & $12: 57$ & $13: 57$ & $14: 34$ & $14: 27$ & $13: 41$ & $12: 36$ & $11: 28$ & $10: 24$ & $09: 45$ \\
\hline 12 & $09: 54$ & $10: 46$ & $11: 48$ & $12: 59$ & $13: 59$ & $14: 34$ & $14: 26$ & $13: 39$ & $12: 33$ & $11: 26$ & $10: 22$ & $09: 45$ \\
\hline 13 & $09: 55$ & $10: 48$ & $11: 51$ & $13: 01$ & $14: 01$ & $14: 35$ & $14: 25$ & $13: 37$ & $12: 31$ & $11: 23$ & $10: 20$ & $09: 44$ \\
\hline 14 & $09: 57$ & $10: 51$ & $11: 53$ & $13: 03$ & $14: 02$ & $14: 35$ & $14: 24$ & $13: 35$ & $12: 29$ & $11: 21$ & $10: 18$ & $09: 44$ \\
\hline 15 & $09: 58$ & $10: 53$ & $11: 55$ & $13: 06$ & $14: 04$ & $14: 36$ & $14: 23$ & $13: 33$ & $12: 27$ & $11: 19$ & $10: 17$ & $09: 43$ \\
\hline 16 & $09: 59$ & $10: 55$ & $11: 58$ & $13: 08$ & $14: 06$ & $14: 36$ & $14: 22$ & $13: 31$ & $12: 24$ & $11: 17$ & $10: 15$ & $09: 43$ \\
\hline 17 & $10: 01$ & $10: 57$ & $12: 00$ & $13: 10$ & $14: 07$ & $14: 36$ & $14: 21$ & $13: 29$ & $12: 22$ & $11: 15$ & $10: 13$ & $09: 43$ \\
\hline 18 & $10: 02$ & $10: 59$ & $12: 02$ & $13: 12$ & $14: 09$ & $14: 36$ & $14: 20$ & $13: 27$ & $12: 20$ & $11: 12$ & $10: 12$ & $09: 42$ \\
\hline 19 & $10: 03$ & $11: 01$ & $12: 05$ & $13: 14$ & $14: 10$ & $14: 37$ & $14: 18$ & $13: 25$ & $12: 18$ & $11: 10$ & $10: 10$ & $09: 42$ \\
\hline 20 & $10: 05$ & $11: 03$ & $12: 07$ & $13: 16$ & $14: 12$ & $14: 37$ & $14: 17$ & $13: 23$ & $12: 15$ & $11: 08$ & $10: 08$ & $09: 42$ \\
\hline 21 & $10: 06$ & $11: 06$ & $12: 09$ & $13: 18$ & $14: 13$ & $14: 37$ & $14: 16$ & $13: 21$ & $12: 13$ & $11: 06$ & $10: 07$ & $09: 42$ \\
\hline 22 & $10: 08$ & $11: 08$ & $12: 11$ & $13: 21$ & $14: 14$ & $14: 37$ & $14: 14$ & $13: 19$ & $12: 11$ & $11: 04$ & $10: 05$ & $09: 42$ \\
\hline 23 & $10: 09$ & $11: 10$ & $12: 14$ & $13: 23$ & $14: 16$ & $14: 37$ & $14: 13$ & $13: 17$ & $12: 09$ & $11: 02$ & $10: 04$ & $09: 42$ \\
\hline 24 & $10: 11$ & $11: 12$ & $12: 16$ & $13: 25$ & $14: 17$ & $14: 37$ & $14: 12$ & $13: 15$ & $12: 06$ & $10: 59$ & $10: 03$ & $09: 42$ \\
\hline 25 & $10: 12$ & $11: 14$ & $12: 18$ & $13: 27$ & $14: 18$ & $14: 36$ & $14: 10$ & $13: 13$ & $12: 04$ & $10: 57$ & $10: 01$ & $09: 42$ \\
\hline 26 & $10: 14$ & $11: 17$ & $12: 21$ & $13: 29$ & $14: 20$ & $14: 36$ & $14: 09$ & $13: 11$ & $12: 02$ & $10: 55$ & $10: 00$ & $09: 42$ \\
\hline 27 & $10: 16$ & $11: 19$ & $12: 23$ & $13: 31$ & $14: 21$ & $14: 36$ & $14: 07$ & $13: 08$ & $11: 59$ & $10: 53$ & $09: 59$ & $09: 43$ \\
\hline 28 & $10: 18$ & $11: 21$ & $12: 25$ & $13: 33$ & $14: 22$ & $14: 36$ & $14: 05$ & $13: 06$ & $11: 57$ & $10: 51$ & $09: 57$ & $09: 43$ \\
\hline 29 & $10: 19$ & & $12: 28$ & $13: 35$ & $14: 23$ & $14: 35$ & $14: 04$ & $13: 04$ & $11: 55$ & $10: 49$ & $09: 56$ & $09: 43$ \\
\hline 30 & $10: 21$ & & $12: 30$ & $13: 37$ & $14: 24$ & $14: 35$ & $14: 02$ & $13: 02$ & $11: 53$ & $10: 47$ & $09: 55$ & $09: 44$ \\
\hline 31 & $10: 23$ & & $12: 32$ & & $14: 25$ & & $14: 01$ & $13: 00$ & & $10: 45$ & & $09: 44$ \\
\hline
\end{tabular}


Day Lengths for the San Juan Study Site from Farmington, N. Mex., 2011

Location: w108 12 , N36 $42^{\prime}$
FARMINGTON, NM

Universal Time

Duration of Daylight for 2011

\begin{tabular}{|c|c|c|c|c|c|c|c|c|c|c|c|c|}
\hline Day & Jan. & Feb. & Mar. & Apr. & May & June & $\mathrm{July}_{\mathrm{y}}$ & Aug. & Sep. & oct. & Nov. & Dec. \\
\hline & $\mathrm{h} \quad \mathrm{m}$ & $\mathrm{h} \quad \mathrm{m}$ & $\mathrm{h} \mathrm{m}$ & $\mathrm{h} \mathrm{m}$ & $\mathrm{h} \mathrm{m}$ & $\mathrm{h} m$ & $\mathrm{~h} \quad \mathrm{~m}$ & $\mathrm{~h} \mathrm{~m}$ & $\mathrm{~h} \mathrm{~m}$ & $\mathrm{~h} \mathrm{~m}$ & $\mathrm{~h} \mathrm{~m}$ & $\mathrm{~h} \mathrm{~m}$ \\
\hline 01 & $09: 42$ & $10: 22$ & $11: 22$ & $12: 35$ & $13: 41$ & $14: 30$ & $14: 38$ & $14: 02$ & $12: 59$ & $11: 50$ & $10: 41$ & $09: 51$ \\
\hline 02 & $09: 42$ & $10: 24$ & $11: 25$ & $12: 37$ & $13: 43$ & $14: 31$ & $14: 37$ & $14: 00$ & $12: 57$ & $11: 48$ & $10: 39$ & $09: 49$ \\
\hline 03 & $09: 43$ & $10: 26$ & $11: 27$ & $12: 40$ & $13: 45$ & $14: 32$ & $14: 37$ & $13: 58$ & $12: 54$ & $11: 45$ & $10: 37$ & $09: 48$ \\
\hline 04 & $09: 44$ & $10: 28$ & $11: 29$ & $12: 42$ & $13: 47$ & $14: 32$ & $14: 36$ & $13: 56$ & $12: 52$ & $11: 43$ & $10: 35$ & $09: 47$ \\
\hline 05 & $09: 44$ & $10: 30$ & $11: 32$ & $12: 44$ & $13: 49$ & $14: 33$ & $14: 36$ & $13: 55$ & $12: 50$ & $11: 41$ & $10: 33$ & $09: 47$ \\
\hline 06 & $09: 45$ & $10: 32$ & $11: 34$ & $12: 47$ & $13: 51$ & $14: 34$ & $14: 35$ & $13: 53$ & $12: 48$ & $11: 39$ & $10: 31$ & $09: 46$ \\
\hline 07 & $09: 46$ & $10: 34$ & $11: 36$ & $12: 49$ & $13: 53$ & $14: 35$ & $14: 34$ & $13: 51$ & $12: 45$ & $11: 36$ & $10: 29$ & $09: 45$ \\
\hline 08 & $09: 47$ & $10: 36$ & $11: 39$ & $12: 51$ & $13: 54$ & $14: 36$ & $14: 33$ & $13: 49$ & $12: 43$ & $11: 34$ & $10: 27$ & $09: 44$ \\
\hline 09 & $09: 48$ & $10: 38$ & $11: 41$ & $12: 53$ & $13: 56$ & $14: 36$ & $14: 32$ & $13: 47$ & $12: 41$ & $11: 32$ & $10: 25$ & $09: 43$ \\
\hline 10 & $09: 49$ & $10: 40$ & $11: 43$ & $12: 56$ & $13: 58$ & $14: 37$ & $14: 31$ & $13: 45$ & $12: 39$ & $11: 29$ & $10: 23$ & $09: 43$ \\
\hline 11 & $09: 50$ & $10: 42$ & $11: 46$ & $12: 58$ & $14: 00$ & $14: 37$ & $14: 31$ & $13: 43$ & $12: 36$ & $11: 27$ & $10: 21$ & $09: 42$ \\
\hline 12 & $09: 51$ & $10: 44$ & $11: 48$ & $13: 00$ & $14: 02$ & $14: 38$ & $14: 30$ & $13: 41$ & $12: 34$ & $11: 25$ & $10: 19$ & $09: 42$ \\
\hline 13 & $09: 52$ & $10: 47$ & $11: 50$ & $13: 03$ & $14: 03$ & $14: 38$ & $14: 29$ & $13: 39$ & $12: 32$ & $11: 22$ & $10: 18$ & $09: 41$ \\
\hline 14 & $09: 54$ & $10: 49$ & $11: 53$ & $13: 05$ & $14: 05$ & $14: 39$ & $14: 27$ & $13: 37$ & $12: 29$ & $11: 20$ & $10: 16$ & $09: 41$ \\
\hline 15 & $09: 55$ & $10: 51$ & $11: 55$ & $13: 07$ & $14: 07$ & $14: 39$ & $14: 26$ & $13: 35$ & $12: 27$ & $11: 18$ & $10: 14$ & $09: 40$ \\
\hline 16 & $09: 56$ & $10: 53$ & $11: 57$ & $13: 09$ & $14: 08$ & $14: 39$ & $14: 25$ & $13: 33$ & $12: 25$ & $11: 16$ & $10: 12$ & $09: 40$ \\
\hline 17 & $09: 58$ & $10: 55$ & $12: 00$ & $13: 11$ & $14: 10$ & $14: 40$ & $14: 24$ & $13: 31$ & $12: 23$ & $11: 13$ & $10: 11$ & $09: 40$ \\
\hline 18 & $09: 59$ & $10: 57$ & $12: 02$ & $13: 14$ & $14: 11$ & $14: 40$ & $14: 23$ & $13: 29$ & $12: 20$ & $11: 11$ & $10: 09$ & $09: 39$ \\
\hline 19 & $10: 00$ & $11: 00$ & $12: 05$ & $13: 16$ & $14: 13$ & $14: 40$ & $14: 21$ & $13: 27$ & $12: 18$ & $11: 09$ & $10: 07$ & $09: 39$ \\
\hline 20 & $10: 02$ & $11: 02$ & $12: 07$ & $13: 18$ & $14: 15$ & $14: 40$ & $14: 20$ & $13: 25$ & $12: 16$ & $11: 07$ & $10: 06$ & $09: 39$ \\
\hline 21 & $10: 03$ & $11: 04$ & $12: 09$ & $13: 20$ & $14: 16$ & $14: 40$ & $14: 19$ & $13: 23$ & $12: 13$ & $11: 05$ & $10: 04$ & $09: 39$ \\
\hline 22 & $10: 05$ & $11: 06$ & $12: 12$ & $13: 22$ & $14: 17$ & $14: 40$ & $14: 17$ & $13: 21$ & $12: 11$ & $11: 02$ & $10: 02$ & $09: 38$ \\
\hline 23 & $10: 07$ & $11: 09$ & $12: 14$ & $13: 24$ & $14: 19$ & $14: 40$ & $14: 16$ & $13: 19$ & $12: 09$ & $11: 00$ & $10: 01$ & $09: 38$ \\
\hline 24 & $10: 08$ & $11: 11$ & $12: 16$ & $13: 27$ & $14: 20$ & $14: 40$ & $14: 14$ & $13: 16$ & $12: 06$ & $10: 58$ & $09: 59$ & $09: 39$ \\
\hline 25 & $10: 10$ & $11: 13$ & $12: 19$ & $13: 29$ & $14: 21$ & $14: 40$ & $14: 13$ & $13: 14$ & $12: 04$ & $10: 56$ & $09: 58$ & $09: 39$ \\
\hline 26 & $10: 12$ & $11: 15$ & $12: 21$ & $13: 31$ & $14: 23$ & $14: 40$ & $14: 11$ & $13: 12$ & $12: 02$ & $10: 54$ & $09: 57$ & $09: 39$ \\
\hline 27 & $10: 13$ & $11: 18$ & $12: 23$ & $13: 33$ & $14: 24$ & $14: 39$ & $14: 10$ & $13: 10$ & $11: 59$ & $10: 51$ & $09: 55$ & $09: 39$ \\
\hline 28 & $10: 15$ & $11: 20$ & $12: 26$ & $13: 35$ & $14: 25$ & $14: 39$ & $14: 08$ & $13: 08$ & $11: 57$ & $10: 49$ & $09: 54$ & $09: 40$ \\
\hline 29 & $10: 17$ & & $12: 28$ & $13: 37$ & $14: 26$ & $14: 39$ & $14: 07$ & $13: 06$ & $11: 55$ & $10: 47$ & $09: 53$ & $09: 40$ \\
\hline 30 & $10: 19$ & & $12: 30$ & $13: 39$ & $14: 28$ & $14: 38$ & $14: 05$ & $13: 03$ & $11: 52$ & $10: 45$ & $09: 52$ & $09: 40$ \\
\hline 31 & $10: 20$ & & $12: 33$ & & $14: 29$ & & $14: 03$ & $13: 01$ & & $10: 43$ & & $09: 41$ \\
\hline
\end{tabular}


ISSN 2331-1258 (online)

https://doi.org/10.3133/ofr20181070 